\title{
BLUEFISH MANAGEMENT
}

Y 4. R $31 / 3: 104-63$

Bluefish Managenent, Serial Mo. 104...

\section{HEARING}

rHE

\section{SUBCOMMITTEE ON FISHERIES, WILDLIFE AND OCEANS \\ OF THE}

\section{COMMITTEE ON RESOURCES HOUSE OF REPRESENTATIVES}

ONE HUNDRED FOURTH CONGRESS

SECOND SESSION

ON

BLUEFISH ON THE EAST COAST, THEIR APPARENT DECLINE, THE EFFECT IT HAS ON THE RECREATIONAL AND COMMERCLAL FISHING INDUSTRY, AND HOW TO MANAGE THEM MORE EFFICIENTLY

APRIL 1, 1996-TOMS RIVER, NJ

\section{Serial No. 104-63}

Printed for the use of the Committee on Resources

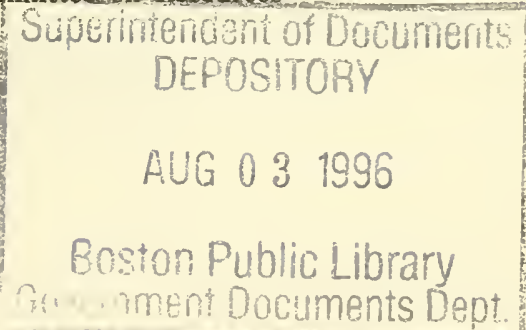

U.S. GOVERNMENT PRINTING OFFICÉ 



\section{BLUEFISH MANAGEMENT}

Y $4 . R 31 / 3: 104-63$

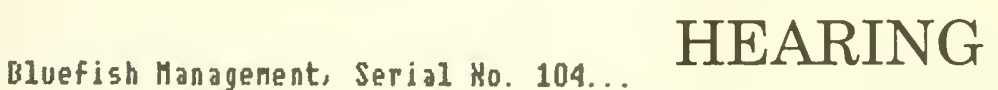

IHE

SUBCOMNITTEE ON FISHERIES, WILDLIFE AND OCEANS

OF THE

\section{COMMITTEE ON RESOURCES HOUSE OF REPRESENTATTEES \\ ONE HUNDRED FOURTH CONGRESS}

SECOND SESSION

ON

BLUEFISH ON THE EAST COAST, THEIR APPARENT DECLINE, THE EFFECT IT HAS ON THE RECREATIONAL AND COMMERCIAL FISHING INDUSTRY, AND HOW TO MANAGE THEM MORE EFFICIENTLY

APRIL 1, 1996-TOMS RIVER, NJ

Serial No. $104-63$

Printed for the use of the Committee on Resources,

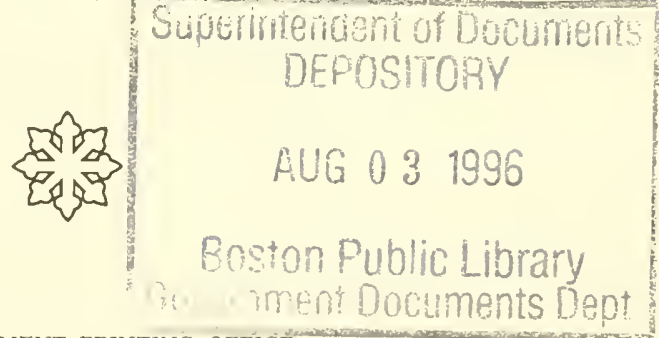

U.S. GOVERNMENT PRINTING OFFICË

WASHINGTON : 1996 


\title{
COMMITTEE ON RESOURCES
}

\author{
DON YOUNG, Alaska, Chairman
}

W.J. (BILLY) TAUZIN, Louisiana JAMES V. HANSEN, Utah JIM SAXTON, New Jersey ELTON GALLEGLY, California JOHN J. DUNCAN, JR., Tennessee JOEL HEFLEY, Colorado JOHN T. DOOLITTLE, California WAYNE ALLARD, Colorado WAYNE T. GILCHREST, Maryland KEN CALVERT, California RICHARD W. POMBO, California PETER G. TORKILDSEN, Massachusetts J.D. HAYWORTH, Arizona FRANK A. CREMEANS, Ohio BARBARA CUBIN, Wyoming WES COOLEY, Oregon HELEN CHENOWETH, Idaho LINDA SMITH, Washington GEORGE P. RADANOVICH, California WALTER B. JONES, JR., North Carolina WILLIAM M. (MAC) THORNBERRY, Texas RICHARD (DOC) HASTINGS, Washington JACK METCALF, Washington JAMES B. LONGLEY, JR., Maine JOHN B. SHADEGG, Arizona JOHN E. ENSIGN, Nevada

DANIEL VAL KISH, Chief of Staff

DAVID DYE, Chief Counsel

Christine Kennedy, Chief Clerk/Administrator JoHn LAWRENCE, Democratic Staff Director
GEORGE MILLER, California EDWARD J. MARKEY, Massachusetts NICK J. RAHALL II, West Virginia BRUCE F. VENTO, Minnesota DALE E. KILDEE, Michigan PAT WILLIAMS, Montana SAM GEJDENSON, Connecticut BILL RICHARDSON, New Mexico PETER A. DEFAZIO, Oregon ENI F.H. FALEOMAVAEGA, American Samoa TIM JOHNSON, South Dakota NEIL ABERCROMBIE, Hawaii GERRY E. STUDDS, Massachusetts SOLOMON P. ORTIZ, Texas OWEN B. PICKETT, Virginia FRANK PALLONE, JR., New Jersey CALVIN M. DOOLEY, California CARLOS A. ROMERO-BARCELO, Puerto Rico MAURICE D. HINCHEY, New York ROBERT A. UNDERWOOD, Guam SAM FARR, California

PATRICK J. KENNEDY, Rhode Island

\section{Subcommittee on Fisheries, WildLife and OCEANis}

\author{
JIM SAXTON, New Jersey, Chairman
}

DON YOUNG, Alaska

W.J. (BILLY) TAUZIN, Louisiana

WAYNE T. GILCHEST, Maryland PETER G. TORKILDSEN, Massachusetts LINDA SMITH, Washington WALTER B. JONES, JR., North Carolina JACK METCALF, Washington JAMES B. LONGLEY, JR., Maine
GERRY E. STUDDS, Massachusetts GEORGE MILLER, California SAM GEJDENSON, Connecticut SOLOMON P. ORTIZ, Texas FRANK PALLONE, JR., New Jersey SAM FARR, California PATRICK J. KENNEDY, Rhode Island

HARRY BURRoughs, Staff Director

Sharon McKenna, Professional Staff

Liz Birnbaum, Democratic Counsel 


\section{O N T E N TS}

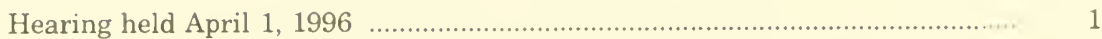

Statement of Members:

Pallone, Hon. Frank, Jr., a U.S. Representative from New Jersey ............. 2

Saxton, Hon. Jim, a U.S. Representative from New Jersey, and Chairman, Subcommittee on Fisheries, Wildlife and Oceans ........................... 1

Statement of Witnesses:

Bogan, Raymond D., United Boatmen of New Jersey and New York ......... $\quad 30$ Prepared statement ...................................................................... 78

Dunnigan, John H., Executive Director, Atlantic States Marine Fisheries Commission .................................................................................... 7

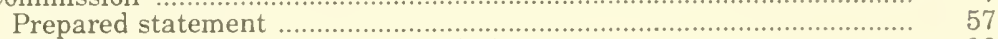

Fote, Tom, Jersey Coast Anglers Association ......................................... 28

Gilford, Dr. James H., Chairman, Mid-Atlantic Fishery Management Council

Prepared statement

Larson, Karter, Barnegat Light, New Jersey, on behalf of Kevin Wark .....

Matlock, Dr. Gary, Program Management Officer, National Marine Fisheries Service

Prepared statement

Radonski, Gilbert, American Sportsfishing Association ....

Prepared statement

Rhodes, Robert "Dusty", Bluefish Committee, Mid-Atlantic Fishery Management Council Prepared statement 



\title{
BLUEFISH MANAGEMENT
}

\author{
MONDAY, APRIL 1, 1996
}

House of Representatives, Subcommittee on FishERIES, Wildlife AND OCEANS, COMMitTEe ON RESOURCES,

Toms River, $\mathrm{NJ}$.

The Subcommittee met, pursuant to notice, at 11:12 a.m., in room 119, Freeholders Meeting Room, Ocean City Administration Building, Toms River, New Jersey, the Honorable Jim Saxton (Chairman of the Subcommittee) presiding.

STATEMENT OF THE HON. JIM SAXTON, A U.S. REPRESENTATIVE FROM NEW JERSEY, AND CHAIRMAN, SUBCOMMITTEE ON FISHERIES, WILDLIFE AND OCEANS

Mr. Saxton. I would like to call this field hearing of the Subcommittee on Fisheries, Wildlife and Oceans to order. This oversight hearing will focus on bluefish on the east coast, not necessarily tuna fish on the west coast.

There is a widespread perception that the bluefish population is diminishing. This is troubling as bluefishing is one of the main draws for tourists in New Jersey and reeling in a large blue attracts many fisherman to this challenge.

I might say for everyone's benefit here that fishing is really a main cog in New Jersey's tourism industry and when people come to the New Jersey shore to fish, there are lots of varieties of fish that they fish for but from a recreational point of view there are basically four. There are other people here who may say there are more than that, but there are east cost tuna fish, there are fluke and the flounder family, there are stripers which have had a great success in helping to herald their comeback and bluefish.

There are many questions about the condition of the bluefish populations. If populations are declining as some claim, why is this happening and what can be done about it? As the Chairman of the Fisheries, Wildlife and Oceans Subcommittee, I consider it my responsibility to help find the answers to these questions.

By way of background, in 1989, a Bluefish Management Plan was drawn up jointly by the Mid-Atlantic Council and the Atlantic States Marine Fisheries Commission. The plan sought to maintain the predominant recreational focus of the fishery by allocating 80 percent of the catch to the recreational sector.

Although the commercial sector had traditionally been fishing ten to 13 percent of the stock, the plan offered room for growth by allocating a full 20 percent to the commercial sector. That growth 
has occurred. Commercial fishing now takes in a full 20 percent of the stock and is subject to the quota limitation.

The plan currently allows only one form of harvest control for the recreational sector, a ten-fish bag limit. Attempts to decrease the bag limit to some lower number, say five or eight or four, whatever, have been met with extreme opposition.

An amendment to the Bluefish Plan will be proposed soon to offer different tools to manage the fishery. Some of the management tools being discussed include the minimum size requirement or establishing a bluefish season. If it is scientifically verified that the bluefish is in serious trouble, actions will be taken to restore the stock.

We in New Jersey have lived through the decline of an economically valuable fish population prior to this. In the late 1980's, as Congressman Pallone and I well remember, population of the Atlantic striped bass started to seriously decline and by 1984, the stocks were in such bad shape, that emergency measures were needed if the species were to survive.

Congress took aggressive action by writing and passing the Atlantic Striped Bass Conservation Act. This Act set up a federally backed mechanism for states to manage the stock. This resulted in a complete moratorium on the fishing of striped bass in states with significant fisheries. All indications are that the Act was successful, so successful that just this past year, the stock has been declared totally recovered and fishing has resumed throughout the Mid-Atlantic region on a recreational basis.

When fishing in state waters resumed, the National Marine Fisheries Service planned to open up the Exclusive Economic Zone or the E.E.Z. to commercial fishing of striped bass. In response to that proposal, I introduced a bill which $\mathrm{Mr}$. Pallone also supports quite actively to continue the moratorium in the E.E.Z. for at least five years and until a fishery management plan has been developed to manage the stocks. After the sacrifices fishermen made to help recover the stocks, in my opinion and I believe in Mr. Pallone's opinion, it would be unwise to allow fishing pressure to build up to an unsustainable level once again.

Are we witnessing a similar problem with bluefish? The purpose of this field hearing is to discuss that very question. We will also be discussing the status of the bluefish population, the best management options and other issues surrounding the fishery.

I will be looking to the National Marine Fisheries Service and the Atlantic States Marine Fisheries Commission for their comments on the Bluefish Management Plan and ways it can be improved to enhance the stock and, of course, I will be looking forward to hearing from our witnesses.

I would now like to recognize Mr. Pallone who is a very active member of the Subcommittee for any opening statement that he may have.

STATEMENT OF THE HON. FRANK PALLONE, JR., A U.S. REPRESENTATIVE FROM NEW JERSEY

Mr. PAllone. Thank you, Mr. Chairman, and I will be brief because I do want to hear from everyone. Let me just say a few things though. First of all, if I could only say and I think most peo- 
ple in the room know that we are very fortunate to have as the Chairman of this Fisheries Subcommittee the only subcommittee in the House of Representatives that deals with fisheries issues, Mr. Saxton.

I certainly don't remember and don't know if there has ever been a chairman of the Fisheries Subcommittee that has been from the State of New Jersey. If it wasn't for the fact that he was the Chairman, it is unlikely that we would even be able to have this hearing today here in New Jersey on bluefish management.

So I want to thank him again for being the Chairman and also for having this hearing which many of you in the audience have requested for some time and we are finally here doing it, which is great.

The second thing I wanted to say is that obviously bluefish is very important and I don't have to tell anybody in this room. I was talking to my Sea Grant assistant here, Mark Chandler on my right, on the way down here today telling him about the historic significance of the bluefish and the fishery.

I have prints in my office that date from the 19th Century about abundance of bluefish being caught in Asbury Park and, if course, you can go way back, you can go back to Colonial times and the records about how important the fishery has been to the Jersey Shore area. It is also one of my favorite things to eat. I love to eat bluefish.

But let me say this though in terms of our hearing today, three things if I could, briefly. One is that in terms of any kind of management plan, I think it is very crucial that NMFS acquire what I call a clear scientific assessment for the decline in bluefish stock.

I have read some of the testimony already and there is obviously a big difference of opinion about what we are doing with our management plan right now. On the one hand, the NMFS people who feel that some sort of bag limit or perhaps a minimum size is important to address the decline in the fishery; on the other hand, some of our local people representing fishing groups saying that that has nothing to do with the decline, that the decline are based on factors that are not going to be addressed by any kind of management plan that looks to bag limits or minimum size.

So there is clearly a problem because we don't know what the scientific reason is for the decline and I think it is crucial that NMFS move in that direction or in some way show convincingly what is causing the decline because otherwise, how do you address it with the management plan.

The second thing I was going to say is that I have been very disturbed by the suggestion that somehow the Mid-Atlantic Council is going to get out of the bluefish management. In other words, it would be turned over solely to the Atlantic States Marine Fisheries Commission.

The local fishermen obviously don't like that because they feel that there is going to be less public input than there would be under the current joint management plan and I would prefer to see that that joint management plan continue.

I know that the proposal to change that is coming from the Administration for some streamlining or reinventing government purpose. I don't see how it helps to reinvent government if it is going 
to do something that cuts back on public input or is not in the interest of the local fishermen. So there is a heavy burden as far as I am concerned to convince me that we should continue with this dual management relationship.

Lastly, I had already expressed to Mr. Saxton and to the various officials that are going to testify here today that I am not in favor and I know Mr. Saxton has said the same thing of moving toward or changing the current regime which is the ten-fish bag limit and I know there is a proposal out there, I guess also from the Atlantic States Marine Fisheries Commission to reduce it to three or to put some minimum size on.

That is not something that I think is the direction we should be moving at this time and again, if that is the direction that someone is proposing they need to do more to show us why they are even making that suggestion because to me it makes no sense given that we don't have any scientific basis for any kind of management plan right now.

But the main thing is to listen to the testimony and I guess maybe I am getting ahead of myself here, Mr. Chairman, but I do appreciate the fact that we are having the hearing and believe me, if it wasn't for him it wouldn't be held. You have to understand that.

[The prepared statement of the Honorable Frank Pallone follows:]

\section{Statement of Hon. Frank Pallone, JR., a U.S. Representative from New} JERSEY

Mr. Chairman, members of the panel: I am pleased to be at Toms River and have this opportunity to address the issue of the management of the bluefish fishery.

Because of the tremendous importance that bluefish have in supporting the recreational fishing effort in New Jersey, I believe it is vital that the National Marine Fisheries Service (NMFS) acquire a clear scientific assessment for the decline in bluefish stock. This will ensure that correct measures to reverse the decline in bluefish will be taken.

I am also concerned about the National Marine Fisheries Service's proposal to place responsibility for managing bluefish under the Atlantic States Marine Fisheries Commission (ASMFC) and exclude the Mid-Atlantic Council. I understand the need for increased efficiency and reduced government regulations. However, the additional input that the Mid-Atlantic Council provides to the New Jersey public is a necessity when trying to create a successful management plan with the many interests involved.

It is my opinion that a new FMP needs to be developed jointly by the Atlantic States Fisheries Commission and the Mid-Atlantic Council with particular focus to the current stock decline and the historic commercial/recreational split.

Mr. SAXTon. Thank you very much, Frank. I appreciate it. Let me just introduce the first panel so they can come forward. Dr. Gary Matlock is Program Management Officer of the National Marine Fisheries Service. Mr. John H. Dunnigan is the Executive Director of the Atlantic States Marine Fisheries Commission. Dr. Jim Gilford is the Chairman of the Mid-Atlantic Fishery Management Council and Mr. Robert Dusty Rhodes, Bluefish Committee, MidAtlantic Fishery Management Council and if you folks would like to take your places.

Let me just say for the members of the public and the press that are here, we have two panels this morning, one of scientific experts who are responsible for designing and maintaining management plans for a variety of activities of fishing particularly in the north- 
eastern part of the country. Then we are going to have a second panel made up of representatives of the local recreational fishing industry which are the group that brought this matter to my attention because of the seeming disappearance of the species from the in-shore waters.

So let me thank you all for being here and I would remind if any other members happen to show up their opening statements will be included in the record. I would like to begin by recognizing $\mathrm{Mr}$. Matlock and let me ask you to try to keep your testimony to five minutes. If you run a little over, obviously we will be understanding but if you would like to proceed, Gary. Thank you.

\section{STATEMENT OF DR. GARY MATLOCK, PROGRAM MANAGE- MENT OFFICER, NATIONAL MARINE FISHERIES SERVICE}

Dr. Matlock. Thank you, Mr. Chairman and members of the Subcommittee, as you have already introduced me I am Gary Matlock. I am with the National Marine Fisheries Service. I am very pleased to be here today to discuss the status of the bluefish stock and its future management.

NMFS has enthusiastically pursued the President's regulatory reform effort over the past year really having started a reinvention effort of regulations similar to the President's almost two years ago.

Our intent is to make the management of fisheries by the governments involved more efficient. In light of that, we have proposed revoking six fishery management plans throughout the country, one of which is the one that is the subject of today's hearing, the Bluefish FMP.

The reason we selected bluefish is that it is predominately found and harvested within state waters and most of the management that goes on now is done by the states. This makes it an ideal species for future management by the states similar to the way in which it is done already.

The recreational fishery for bluefish which is approximately 80 percent of the total fishery takes places primarily in state waters. For example, in 199411.1 million bluefish were estimated to have been taken in state waters versus only about 819,000 fish caught in the E.E.Z.

The Atlantic States Marine Fisheries Commission and Atlantic Coast States are heavily involved in the managernent of this species in both state and Federal waters and the Commission already has in place an existing interstate fishery management plan for Atlantic bluefish.

I would note here that their plan is exactly the same plan as that that exists or that was implemented by the Mid-Atlantic Council. The Commission's plan outlines a comprehensive management strategy for bluefish and again is identical to that implemented by the Council.

The time is right now however with the passage of the Atlantic Coastal Fisheries Cooperative Management Act for management of this fishery to become more efficient. The Atlantic Coastal Act is a more appropriate vehicle than the Magnuson Act for advancing state's interest in a species that is harvested predominately in state waters. 
Another added benefit of shifting bluefish management primarily to the Commission is that it will enhance public input by simplifying the number of management bodies with which the public will have to interact. The Commission has recently implemented a strong program for public involvement in their fishery management process. Therefore, there should be ample opportunity for the public to stay involved under the Commission's plan.

$\mathrm{Be}$ assured though that if there is a need for additional Federal regulations to buttress the Commission's plan, the Commission can recommend that the Secretary take action with respect to the E.E.Z.

Let me emphasize that NMFS does not intend to withdraw the FMP without the Commission's recommendation to the Secretary enabling Atlantic Coastal Act regulations to be implemented in the E.E.Z. thereby insuring that there is no lapse in E.E.Z. regulations due to this process nor no reduction in the protection of bluefish.

The Federal interest in this important fishery will be maintained through NMFS ongoing cooperation with the Commission and its involvement with the Council under the authority of the Atlantic Coastal Act. In the future bluefish management decisions would be made by the Commission with supportive action taken by the Secretary after consultations with the Mid-Atlantic, New England and South Atlantic Councils.

Let me emphasize that NMFS will take whatever supportive measures are necessary for the conservation of bluefish either through issuing complementary regulations in the E.E.Z. or imposing moratoria in state waters when states do not comply with the Commission's plan as authorized and mandated under the Atlantic Coastal Act.

We just released the proposed rule on the Atlantic Bluefish FMP on March 28. The 45-day comment period will end on May 13 and we would encourage anyone who has an interest in this topic to submit comments to us. We want to make things better for this resource and keep it out of further risk.

NMFS agrees with the Subcommittee's observation that the bluefish stock is declining. The latest stock assessment finalized in 1993 found that the bluefish stock is over exploited and at a low level of abundance. Spawning stock reached a historical high in 1986 and has since been in a steady decline. Commercial landings over the last decade have remained stable but recreational landings have declined significantly.

The over exploitation of bluefish by fishing in recent years, at least since 1986, certainly is a factor in the continued rate of decline of bluefish stocks. Other factors such as environmental conditions also have a role in the decline of this species.

We do not believe that there is new predation pressure on the stocks. It has been suggested that the recent increase in the abundance of striped bass has had an inverse effect on bluefish abundance because of increased striped bass predation on juveniles.

Considering the fact that striped bass stock abundance has undergone a major increase since 1989 , and bluefish stocks were already in a steady decline for a number of years before that, it is unlikely that increased striped bass abundance has been a major 
factor in the decline of bluefish. The timing just simply doesn't match up.

In addition, water temperature and currents can effect the migratory patterns and distributions of fish. We have supported and cooperated in research by the Marine Resources Center at the State University of New York at Stoneybrook to investigate these and other questions regarding bluefish recruitment mechanisms. These questions have yet to be fully resolved.

The best way to manage the stock for growth is to control fishing mortality in order to maintain a large spawning stock biomass. The spawning stock biomass should be large enough to quickly rebuild the stock when as yet unquantifiable environmental factors favor such rebuilding. Thus, we should manage for lower fishing rates and higher stock sizes for bluefish as this will provide for a more stable stock under conditions of environmental uncertainty.

Through NMFS partnership with the Commission's and the Council's Fishery Management Planning Program we will remain committed to conserving bluefish and with that, Mr. Chairman, I would be glad to entertain any questions that you might have. I would also note that you should have received copies of my written testimony that I would like to have entered into the record.

[The prepared statement of Dr. Gary Matlock may be found at end of hearing.]

Mr. SAXTON. Thank you very much. We are going to hear from the entire panel and then we will get into some questions. Mr. Dunnigan.

\section{STATEMENT OF JOHN H. DUNNIGAN, EXECUTIVE DIRECTOR, ATLANTIC STATES MARINE FISHERIES COMMISSION}

Mr. DUNNIGAN. Thank you very much, Mr. Chairman, and members of the Committee. I am Jack Dunnigan, the Executive Director of the Atlantic States Marine Fisheries Commission. It is a pleasure to be back in coastal New Jersey again.

The Committee has invited me to this area before and it has always been, I think, a good opportunity to get out and listen to the fishermen who are involved with these programs on a day-to-day basis.

My testimony has been submitted for the record and I would ask at this time that it be included in full and if it pleases the Chairman, I will just go ahead and make a couple of comments based on it.

I would like to recognize at first a couple of people who are here, $\mathrm{Mr}$. Tom Fote is one of our ASMFC Commissioners. He is from Toms River and he is, of course, no stranger to the members of this Committee.

A couple of other New Jersey people who are involved in our process, Dusty Rhodes who is on the panel is the Chairman of our Bluefish Advisors and Charlie Bergman from Cape May is also in the audience and is an advisor that we rely on for a number of our fisheries.

Also with me is no stranger to this Committee, Lori Rosa who used to work with you folks before joining the ASMFC staff; and John Carmichael is our bluefish technical expert and our manage- 
ment plan coordinator. So if need any technical support today, I think John will be able to give it to us.

Mr. Chairman, bluefish are a species that is found all over the world and we, of course, are most interested in that species as it exists along the Atlantic Coast. At present, the bluefish stocks in the Atlantic Ocean appear to be in a period of serious decline. The target fishing mortality rate of the fishery management plan seems to have been exceeded in every year since 1986 .

The stock biomass has declined from 326,000 metric tons in 1982 , the historic high, to 86,000 metric tons in 1993 . We cannot expect to have large recruitment and large spawning stock sizes on a regular basis. But recruitment since 1989 has been below average. In the 1993 year class of four million fish was the poorest surveyed during the last 20 years.

The National Marine Fisheries Service fall survey in 1994 indicated some improvement in recruitment for the 1994 year class, but the overall picture is still disappointing; and not surprisingly the decline in the size of the stock has been reflected in the lack of success in commercial and recreational fisheries.

This resource has been under cooperative management since 1989 and I would like to make a comment about the nature of the cooperative process between the Atlantic States Marine Fisheries Commission and the Mid-Atlantic Fishery Management Council.

Mr. Chairman, when this committee or its predecessor considered the Atlantic Coastal Fisheries Cooperative Management Act two years ago you made a great point for us to hear that you wanted to see greater levels of cooperation between the Atlantic States Marine Fisheries Commission and our partners in the Federal Government; and we have been making every effort to continue to do so.

The Bluefish Fishery Management Plan was the first one that was developed cooperatively by our two organizations and throughout that, the staff of the Mid-Atlantic Fishery Management Council has always taken the lead in putting the cooperative program together.

As Mr. Matlock said, the current fishery management plan isn't really an ASMFC plan or a Mid-Atlantic Council plan. It is a joint document. Both organizations have adopted exactly the same language and mutually implement on a continuing basis the management measures that are contained in that document.

We are now in a position where we have recognized jointly that the current fishery management plan for bluefish is inadequate to meet the needs of the fishermen and of the resource today.

The problem is that this was adopted in 1989 and we have learned an awful lot since then about how the resource operates and about how fishermen operate and at the same time we have seen the resource undergo a serious period of decline.

As a result, the Commission and the Council decided about a year and a half ago that we desperately need a new fishery management program for bluefish. Let me give you a couple reasons why, some of which were alluded to by the Chairman in his opening statement.

The Bluefish Management Plan has some very blunt instruments to be used to try to conserve and manage this fishery. In the rec- 
reational fishery, for example, the only measure that we can implement if we want to try to reduce fishing mortality is to change the bag limit. The bag limit is at ten fish per day and even that measure was quite controversial in New Jersey when it went into effect in 1989.

If we want to try to reduce fishing mortality say by 20 percent, it doesn't mean that you just reduce the bag limit by 20 percent since very few fishermen are harvesting at the rate of the bag limit.

If you want to try to reduce fishing mortality, if the only thing you can do is reduce the bag limit, you might have to reduce it from ten to five or to four or something like that in order to pick up enough of the fishery to have the requisite change in fishing mortality that you are looking for.

The plan doesn't allow us to vary size limits, or to vary seasons. We need more tools in this fishery management plan for the council and for the states to use in arriving at a management program that meets both the needs of the resource and the needs of the fishermen and I think similarly so for the commercial fishery.

It is very difficult to just take a simple rule that says that we will calculate the recreational fishery, multiply it times 0.2 and that is the commercial quota. A lot of that has been based on some history that is behind us now and we ought to have as managers, the Commission and the Council, the opportunity to look more carefully at what we are really trying to do with this fishery.

It is critical that we get the amendment to the Bluefish Fishery Management Plan done this year. Everybody, I think, agrees with that. We have been frustrated, all of us, for the last couple of years that the processes have taken so long to wrap up so we would place great emphasis on making sure that the management process this year can respond to the need to have the plan implemented as soon as possible.

Now dealing with the question of the proposed withdrawal of the Secretarial approval of the Bluefish Fishery Management Plan, the Atlantic States Marine Fisheries Commission is going to wait until we have an opportunity to look at the specific language of the Federal Register Notice that was published last Thursday before we make any formal substantive comments on what is being proposed.

We are, however, disappointed at the manner in which this matter was handled. We were not given notice. The Council was not given notice. This is not the way that partners should be working if they are trying to work together on a cooperative fishery management program.

We have every reason to believe that this was not the idea of the National Marine Fisheries Service to try to handle it this way. We assume that it came from elsewhere in the Administration.

The leadership of the National Marine Fisheries Service has been very gracious in working together and trying to build a solid working relationship between the states and the Federal Government so we are disappointed in the way it was handled.

We will be commenting specifically on the substance of the proposal as soon as we have an opportunity to do so. Mr. Chairman, with that, I think I would like to stop now and take any opportunity to answer questions. Thank you again for inviting us today. 
[The prepared statement of John H. Dunnigan may be found at end of hearing.]

Mr. SAXTON. Thank you very much, Mr. Dunnigan. Dr. Gilford. Dr. Gilford is also with the Mid-Atlantic Fishery Management Council. Go ahead, sir.

\section{STATEMENT OF DR. JAMES H. GILFORD, CHAIRMAN, MID- ATLANTIC FISHERY MANAGEMENT COUNCIL}

Mr. Gilford. Congressman Saxton, Congressman Pallone and your associates up there that we affectionately refer to as staff, thank you very much for the opportunity to be here today. I am James Gilford, chairman of the Mid-Atlantic Fishery Management Council and I very much appreciate the opportunity to present testimony here today on the Federal role on the management of bluefish.

The Mid-Atlantic Council members have received copies of my testimony and at their next meeting which begins tomorrow they will take a formal position with respect to the proposal to withdraw the existing Bluefish Management Plan.

For that reason my comments today represent my views and not necessarily those of the Council. With your permission I will submit to the Subcommittee the Council's position immediately following our upcoming meeting.

I will direct my testimony to the three items of concern as stated in the letter of invitation to participate in today's hearings; namely, the decline in bluefish stocks, the possible effects on bluefish management of withdrawing the existing Bluefish Management Plan and appropriate measures which could be used to manage bluefish under amendment one of the existing management plan.

To avoid repeating things that Jack Dunnigan has already said, I certainly agree with his comments with respect to the cooperation between the Council and the ASMFC and I think it has been an extremely positive and encouraging relationship.

I would like to make it very clear that in my view there is no turf issue involved here with this concept of withdrawing the bluefish plan. This is strictly a question of what is a proper and effective and efficient way of managing a fishery stock.

First, there does appear to be a decline in bluefish stocks. Based on a 1994 stock assessment by the Northeast Fisheries Science Center Stock Assessment Workshop which is the best scientific information available to us right now, bluefish currently are considered to be overfished.

The spawning stock biomass has declined by 74 percent between 1982 and 1993. Recruitment has been poor and the 1993 year class is the smallest of any in the past decade. Since fishing mortality rates have only recently exceeded the biological reference point, thus indicating overfishing has occurred. It is possible that the consistent decline in recruitment observed in recent years is responsible for decline in stock biomass.

Even so, the results of the most recent stock assessment suggests that fishing mortality should be reduced to stabilize bluefish stocks and prevent further declines and there are a number of mechanisms that can be used to reduce that mortality without necessarily 
restricting bag limit. As Jack pointed out, that is the kind of tools we are looking for to re-write the management plan.

I am not aware of any effort to evaluate the effects of increased predation or changes in water currents or water temperatures on the distribution and abundance of bluefish. However, there is one study underway to assess the possibility that the greatly increased abundance of striped bass could have displaced bluefish offshore.

Since most recreational landings of bluefish are attributed to fishermen fishing close to shore, such a displacement might also account for the decline in recreational landings in recent years.

I might also add, sir, that our watermen in the Chesapeake Bay have been telling us for years that there is some correlation between bluefish abundance and striped bass abundance at least in the Bay.

You asked what effect the proposed withdrawal of the Bluefish Management Plan might have on bluefish management, on the resource and on public input. The amount of work required to properly manage bluefish will not be reduced by withdrawing the existing plan.

The effort to amend the plan will be the same. The amount of effort required to implement the plan will be the same. Scientists, plan developers and fishery managers will still need as much data collection support and updated stock assessments as ever. However, the personnel and resources to accomplish all of this will be significantly reduced by withdrawal of the plan and eliminating Council participation at least at the working level.

The amendment process will be prolonged and yet the opportunity for public input during the amendment process and implementation of the amended plan will be greatly reduced. I believe the Atlantic States Marine Fisheries Commission is every bit as concerned as the Council about the condition of bluefish stocks.

Nevertheless, assigning sole responsibility for bluefish management to ASMFC or to any other management entity in itself ignores as a matter of expediency the resources needed to amend the plan, to implement it and to monitor its effectiveness so as to maintain the well being of the resource while responding to the needs and desires of recreational/commercial users.

The proposal to withdraw the Bluefish plan also deprives the user community of a fair and meaningful participation in a management process assured it by the National Standards and other provisions of the Magnuson Act. I see no benefit to the resource or to the fishing community in the proposal to withdraw the Bluefish Management Plan that now exists.

A management strategy similar to that which is working for summer flounder appears to be adaptable to managing bluefish stocks for growth. The strategy involves setting a target fishing mortality rate consistent with achieving an increase in stock biomass using that target rate in a stock assessment to calculate a total allowable catch and allocating that total allowable catch to the recreational commercial fisheries based on some agreed-upon formula such as in the case of bluefish, the 80/20 allocation specified in the current management plan.

Given that the Bluefish Plan includes both recreational and commercial users and that it will extend along the entire Atlantic 
Coast, there are likely to be allocation issues. However, if amendment one is prepared under the Magnuson Act required adherence to national standards, a provision unique to the Council process, is assurance that allocation issues will not out-weight protection of the fisheries.

Again, I thank you for the opportunity to offer this testimony.

[The prepared statement of Dr. James H. Gilford follows:]

Mr. SAXTON. Thank you very much. Mr. Rhodes, you may proceed.

\section{STATEMENT OF ROBERT "DUSTY” RHODES, BLUEFISH COMMITTEE, MID-ATLANTIC FISHERY MANAGEMENT COUNCIL}

Mr. RHodes. Thank you, Mr. Chairman, Congressman Pallone and staff. You have my written testimony which I trust you will put into the minutes and I am going to comment on three points briefly relative to the three issues which you raised in your invitation.

The bluefish stocks may very well be in trouble but they may not necessarily be in biological trouble. There are some severe questions as to whether the science that we have to date adequately reflects the condition of these stocks and I think that with bluefish more than any stock we have an opportunity to over-regulate and we need to move forward very cautiously.

As a member of the management process I am concerned that the absence of hard data concerning why these fish have seemed to be less available in recent years than before might lead us to assume over fishing is a major ingredient when in fact it is not.

There may be one answer to help alleviate that problem. As we sit here today the Fishery Service, the Commission and the Council are working together in the development of an integrated data base and an information system that would put along the entire east coast a common data for everyone to make decisions from and I can assure you from my days in data processing that there is nothing more important to decisionmaking than an integrated data base and common information.

I can think of no better time however to incorporate in that data base information which we call on the water information, heretofore called anecdotal information. There is a body of credible information available from serious recreational and commercial fishermen that has been ignored far too long.

I can think of no better time than during the development of this data base and during the questions on bluefish, an excellent fish to use that information with, no better time to incorporate that data and I urge you folks to provide input into this whole process to ask for the inclusion of this important data which has too long been ignored.

I would hope that those of us on the management side who pass judgment on what information to use would not be guilty of $\mathrm{NIH}$, not invented here, and would not continue to ignore that important body of evidence. This is the time to incorporate it while the data base and the system is being developed and bluefish are a particular stock where I think that data can be very valuable.

The second question deals with the movement of the responsibility of the plan from the Council to the Commission. I oppose that 
very significantly and not because the Commission is not capable of managing stocks. On the contrary, the very people who sit on the boards are also on the councils. State directors certainly have that expertise.

Nevertheless, there is an essential difference in the make-up of the councils and the commission that I think should be addressed. When Congress put together the council system its intent was to provide for more public input.

That is provided not just by canvassing the public but essentially by the presence on the council of public members who can bring that kind of information to bear although Jack Dunnigan has done an excellent job in erecting an advisory system and I, in fact, am part of that but there is not the same make-up on the board as there is on the council.

I think the synergy between that has developed between the council and the commission working together with these additional industry members contributes significantly to public input not at the hearing process, not at the advisor process, but at the decision process. For that reason, I oppose the elimination of the council from the decision process.

There is a second reason. Why pick bluefish? If, in fact, bluefish are to be moved then any species that we have a joint plan for could possibly be moved. Is this a de facto way to reexamine and reorganize the management system? I have said many times that the journey is as important as the destination. If, in fact, we are going to do that then let's do it substantively. Let's not back our way into it. If we are going to reexamine how we do things into the next decade, then let's put an effort together to reevaluate that, to reexamine it but let's not do it by selecting one particular plan and moving it over under the guise of reducing paperwork. I don't think the paperwork will be reduced and I don't think this is the way to go about a reexamination of how we manage fish if, in fact, that is what is on the table here.

Finally, you have my comments concerning changes to the Bluefish Plan and indeed whether or not the stocks are depressed, the Bluefish Plan needs to be updated and modernized and flexibility needs to be built in but there is one issue that I want to address.

It is a very serious one and it runs through a number of fishery plans, the scup plan, the black sea bass plan, the blackfish plan and now the bluefish plan has a very great opportunity of ignoring and eliminating from participation of the fishery a class a recreational anglers, namely the shore bound angler.

By virtue of minimum size implementation the jetty, the pier, the river, the sedge bank angler can be leveraged right out of this fishery and yet we have no scientific information indicating the impact of their fishing pressure. Yet by implementation of minimum sizes and without consideration of this sector, we are very rapidly eliminating that portion of the recreational sector from participation in fishing and taking home a fish.

I think that is wrong and we as managers need to reexamine some of these measures and we need to be pressed to examine some of those measures and I am very concerned that although we seek controls and seek flexibility, we may very well be saddling the management process with yet another albatross; that in fact, the 
only recreational angler we are concerned about are those who can afford boats or who can afford passage and party charter boats.

I don't think that we are going to achieve public acceptance of what we do or necessarily good controls by eliminating what may be a de minimis portion of the fishing public and yet we are headed in that direction. That concludes my comments and I guess now we are ready for questions. Thank you again for giving me this opportunity.

[The prepared statement of Robert Dusty Rhodes may be found at end of hearing.]

Mr. SAXTON. I thank each of you for sharing with us your individual perspectives. Let me make a suggestion, Frank, and members of the panel. Since we are not in Washington and since we have the luxury of not having to face votes and bells and time limits, why don't we make this question and answer period more informal and more of a discussion and therefore, if you want to jump in at any point please, Frank, feel free to do so.

Let me begin with a very basic question. It seems to me that each of you perhaps with some variation have all agreed on one point and that is that the bluefish stock appears to be less than it was and there is apparently some evidence that it is continuing to shrink.

One set of figures, which I believe Mr. Dunnigan pointed out, suggests that the bluefish stock peaked in 1982 with about 326 metric tons and in 1993, the last figures we have available, the metric ton number shrunk all the way to 86,000 . That appears to me to be very significant.

Also, the take has shrunk significantly from 23 million pounds in 1980 according to $\mathrm{Mr}$. Matlock to 12 million pounds in 1994, a reduction of 50 percent, which seems to be very significant. Do you all agree therefore that this is a problem? I got comment from some individuals who heard about this hearing that this is part of a cycle and that we shouldn't worry about it.

I guess we all agree that the population is down significantly and I guess that is the question. Mr. Rhodes may perhaps be taking a different view and that is fine. Would you all comment on that, not necessarily in order and Mr. Rhodes, why don't you start?

Mr. RHODES. I do believe the evidence indicates that the fish are not as available. I am questioning however whether that means that the biomass is really as declined as we think it is.

We generally apply the measurement process in terms of recruitment, in terms of catch, to the conclusion that the biomass is reduced and that may very well have been upheld in other fisheries but because of the history of bluefish, I am not convinced that we have enough scientific evidence to say that the reduced recreational availability and notice that it is the recreational availability that has been more reduced that the commercial availability. Commercial catch has been maintained on a relatively stable basis.

I think the fish are certainly not as available. I am not sure, however, that that necessarily concludes that the biomass is as depressed as some would have us believe and that is why I think that as managers we need to proceed very cautiously to make sure that fishing pressure is as important as I think it is and that is why I suggest the on the water information of credible, full time rec- 
reational and commercial fishermen be included because that may very well tip the decision one way or another concerning where the biomass is headed.

Mr. PALlONE. Mr. Chairman, could I just ask, this concept of biomass which is a scientific one, am I right in this analysis? In other word, theoretically you could have this biomass out there, this level of spawning fish, I guess, whatever, and if it isn't decreased in a fashion and I don't know how to phrase this because I just want to get to the bottom in terms of how I am looking at it, we may have say like 100,000 bluefish and only need a biomass of 5,000. In a given year, you might have 100,000, you might have 50,000.

The question really is whether this biomass which is sufficient to keep the fishery going historically is diminished. Is that what we are asking? You are saying, Dusty, that there isn't any evidence, scientific evidence, right now to see to what extent this biomass is diminished. In other words, theoretically you could have a lot less fish out there but the biomass isn't implicated in any way. In other words, I don't know what we are talking about here.

Mr. RHODES. I am not saying that there is no evidence. I am just raising the question that perhaps the unavailability of bluefish to the coastal recreational angler is not necessarily a true indication of what has happened to the biomass.

The biomass may have reduced but it may not have reduced as much as we think it has reduced. We are saying that unavailability of fish is one of the measurements that indicate a biomass is not there.

The fish may be for various reasons further off shore than the recreational anglers in general can reach them because we have seen movements of fish appearing elsewhere along the coast that can't be explained.

In the Gulf of Maine, for example, an abundance of bluefish has been seen where in the past we haven't seen those and big bluefish in the Florida Keys where in the past we haven't seen those fish. Why are those fish being seen? This is why I am saying that on the water information is necessary to help round out what we are assuming by the scientific sampling.

But biomass may be down and we may, after doing some more analysis, conclude yes, we have to put very serious constraints on the fishery. I just don't know that we have enough information to make that hard and fast decision that the biomass is truly reduced and that is why I am asking that we incorporate more information in this assessment.

Mr. SAXTON. This is a very basic question I think that has come up with regard to this subject. Would you gentlemen care to comment to give us your perspectives?

Mr. GILFORD. The scientists are not in agreement as to what has happened. The one thing they seem to be in agreement about is, in fact, that the biomass is down. That could be either because of over-fishing or it could be because of lack of recruitment or a possibility of the combination of the two.

We have had commercial fishermen attending our Council meetings telling us that they are seeing well off shore large schools of large bluefish. What you have if, and let me emphasize the if, if you are not having good spawning, if you are not having good re- 
cruitment, what you are essentially doing is burning a candle at both ends if you continue to fish and your fishing mortality stays high.

What you are looking at essentially if your spawning is poor and say the 1993 year class was the poorest in the past decade and if you don't have any young coming into the fishery and you are taking or cropping off at the top of that fishery or at the small size of the fishery, either end, and you have nothing to replace it, your stock has got to go down, both your spawners and anything that might recruit to it.

So I think one of the things we really need to understand is what is taking place both with spawning and with recruitment so we have some idea of what the biomass really is and what is happening to it.

I think Dusty is absolutely right. It may not be over fishing as such. The problem is that if you have a fixed resource, nothing coming into it and you fish on it, what it means is that the next time your spawning stock has an opportunity to spawn successfully, there will be fewer of those fish there to spawn if you have harvested them off. So that may very well be the kind of situation we are facing, that over fishing per se may not be the problem but it may be part of what has to be done to cure the problem.

Mr. SAXTON. Mr. Dunnigan.

Mr. DUnNigan. Yes, thank you. I think that Dusty and Jim are both hitting on good points and I would support almost all of what they say.

I think that the point that Dusty is raising about the need to more fully integrate what we hear from the fishermen on the water into the scientific analysis is a very important one. We are looking at data. When we do good science, the best available science, we are looking at data that is old. It is information that was collected maybe a year or two ago.

Once we get information it takes a while to check it out make sure that it doesn't have data errors in it and to work it through the system to the point where the stock assessment scientists can use it and then they take time to argue out among themselves as to what is right or wrong or important or unimportant about the information.

So the best scientific information available is almost always going to be somewhat out of date and so it is very important when the managers sit down and try to figure out how to work this in and make an evaluation of what the right policy for that fishery is as opposed to science.

It is very important for them to be working closely with fishermen so that they can ground truth what it is they are working on. So I think it is a very important point that Dusty is making.

Mr. SAXTON. Mr. Matlock.

Dr. MATLOCK. I think in response to the basic question that you asked, Mr. Chairman, which is whether or not there is agreement that the spawning stock biomass is decreasing, it seems to me that there is not very much disagreement about that basic question.

There is disagreement about the causes for what people have concluded is and has occurred and even though we may be behind a year or so in the estimates that get generated and the assess- 
ments that get done and so on, it still does not alter, I think, the answer to your elemental question and that is, is the spawning stock going down.

The answer almost unequivocally is yes. The reasons for that decline, those I think are at issue and there is not as much agreement on those. Not having been here during the striped bass discussions and debates but having been aware of them from a distance, it seems to me that there are similar kinds of questions and discussions going on with respect to bluefish as were going on with striped bass. So any time there is a substantial decline, I think generally there are questions and issues about the reasons for those declines.

Mr. SAXTON. Let me ask one final question and then I will lateral to Frank. It seems to me that at least from a common sense point of view that if this problem was created to a significant degree by a shrinking of the biomass, meaning less fish, there would be somewhat less fish on shore when, in fact, fishermen who talk to me tell me there are virtually no fish on shore and it seems to me that one might want to look at the onshore areas to figure out if something else is going on. Would you comment?

Dr. MATLOCK. I think your conclusion is a safe one to reach. If there are no fish in a certain area, it is certainly wise to look at that area and try to understand why they may not be there.

One of the first explanatory outcomes of that in the face of a declining total, there are fewer total fish to be distributed to various places, is that you would expect to see fewer fish in all places except where they end up getting concentrated as stocks generally decrease in size.

So it is an expected outcome as the total goes down to see fewer fish in areas where they generally have occurred when the stocks were higher. Beyond that, trying to find out exactly why there are fewer fish in a particular area is a worthwhile endeavor to pursue. It is not wise though from a prudent management standpoint where the things that you can regulate are essentially restricted to fishing to not do anything in the areas where you can do something because you don't know everything there is to know about why fish are distributed.

Mr. SAXTON. Yes, but that doesn't mean that we shouldn't be looking. For example, and I don't know if this is accurate or true or partly true, but it seems to me that if food disappeared from the onshore areas the bluefish might go someplace else to find food and there are perhaps other fishing practices in other fisheries, i.e., bunkers, that may hold the answer. I don't know that that is true but is that something that we ought to look at? Dusty.

Mr. RHODES. I definitely think all those variables, Mr. Chairman, and someone recently did an analysis and I got a copy of it of the recreational catch over the last 12 to 13 years and I don't think this has yet been entered into the scientific body.

There was a plot of the percentage of various year classes age fish in the recreational catch and the distribution of ages over the 12 year period was almost identical and the question remains if the fish are in such decline, how could recreational people for 12 years running catch the same percentage in their total catch of certain year classes. That would mean that whatever is declining, the fish 
would have to do it evenly over all year classes. I would think that is an almost impossible scientific happening.

Therefore, the question of movement because of physical conditions, food, temperature, et cetera, I think is a valid one and I think that needs to be answered and investigated and purified and in effect, vetted through the system and I don't think it has yet.

So yes, I agree with you and that is another reason why this on the water information is so important. We don't look at interactions of species when we manage fish. That is a very complicated process.

It is also a very frustrating one because we know the fish in the real world do interact and yet we look at them individually. This may be an excellent time to start to examine some of those interactions.

\section{Mr. SAXTON. Frank.}

Mr. PALlone. Thank you, Mr. Chairman. I wanted to get into the issue of the joint management but before I do that if I could just follow up on what Mr. Saxton said. The problem it seems to me is that unless we have scientific basis for knowing whether these management plans are really going to help, there are always going to be unacceptable to the average fisherman because they are going to be suspect not having been scientifically based so I think the need to get a scientific basis as to why the decline is occurring is crucial. Otherwise, the fishing public is never going to believe that there is any need for management.

I guess my problem is, two things, first of all, one of you mentioned this Stoney Brook study, I guess that was Mr. Matlock, are dealing with the currents and you said, I think, that basically and I don't know if it is not completed or it is not definitive, what is the status of that?

Dr. MATLOCK. I don't know the exact status of it. I will have to get back to you and tell you what that is so that I am correct in answering it but my understanding to date is that the results have just simply not been determined or convincing that there is a particular conclusion that can be reached but rather than go much further than that, if you don't mind I will be happy to give you a written response.

Mr. PALlONE. All right. Then the other thing is I gather that the Commission if you will has dropped this proposal that we were hearing a few months ago about reducing the bag limit from ten to three and having some sort of minimum size. For the time being that has been dropped and yet you haven't put forward and many would have said that we can't continue with the current scheme and we are going to come up with a new one but so far we don't have the new one, I guess.

My question, I guess, first of all is what was the reason why you proposed that original one and now it has been dropped? Is it just the public outcry against it? That is a legitimate reason to drop it but I just don't understand how we go from ten to three and we don't have a scientific basis. How are you going to come up with a management plan that is different from the current one without any more scientific data which we don't seem to have? 
Mr. Dunnigan. Well, Mr. Pallone, we do have more scientific information than we had when we adopted this management structure in 1989. Most recently, we have the 1993 stock assessment.

Mr. PALlone. But again, this is just based on stock as a whole as opposed to the actual cause for the decline is what you are saying?

Mr. Dunnigan. Yes, that's true.

Mr. PALlONE. So you may just go ahead based on the fact that the stock is declining and say, OK, we will put in some more severe restrictions or whatever just because the stocks have declined without knowing if the management plan is actually going to help.

Mr. DunNigan. There are a couple of interesting things about this. First of all, if you have a stock that is let's say at 200,000 metric tons and you are taking perhaps ten million pounds out of that and that stock declines to 100,000 metric tons, you can't continue to take ten million pounds of fish out of that without having a dramatic increase in fishing mortality.

So if the stock declines whether or not it was fishing that caused it, the management structure has to respond somehow to that change in the stock size so there would be some need for regulation at that point.

If you are going to reasonably and prudently deal with that resource so that it will have an opportunity even if it is just riatural cycle so that it will have an opportunity to respond when those cycles are set up to a point where the resource is ready to come back.

Mr. PALLONE. I guess my problem is and I guess we will have to hear from the next panel but I get the impression from some of the testimony from the next panel that they just don't agree with the underpinnings of what you said and they don't believe that just because the stocks have declined that means that we should approve this kind of management plan.

I don't know. Let me get into this second thing because this is very important to me and this whole thing of eliminating the joint management between the Commission and the Councils.

It seems to me that this is totally absurd and it seems like it is coming out of the Administration in some fashion through their reinventing government routine which we, of course, have been hearing about for some time and which generally, the idea of reinventing government and cutting back on red tape, paperwork, number of employees, all that makes sense.

But where in the world did this thing come from? Obviously, it is not coming from Fisheries personnel. Is it coming from OMB? If it is coming from OMB or directly from somebody in the White House, who did they consult with?

Mr. Dunnigan. I think Mr. Matlock is actually volunteering to handle this one.

Mr. PALlone. All right.

Dr. MATLOCK. Actually I am because I would like to make sure that you know it did not come from OMB. It did not come from anywhere but the National Marine Fisheries Service.

Mr. PALLONE. OK.

Dr. MATLOCK. We recommended it on the basis that this Fishery is a state fishery primarily. The passage of the Atlantic Coastal Fisheries Cooperative Management Act in 1994, I believe, set the 
stage for us to work more directly with the Commission, the Atlantic States Marine Fisheries Commission for predominantly state fisheries so that the management could become more effective.

We proposed, for example, last year before the regulatory reform initiative began to either withdraw the American Lobster FMP, which is currently a Council FMP, manage it through the Commission's FMP. This is the same process that we are proposing for bluefish, and we told folks a year before we actually proposed it, that there may be a proposal that would be forthcoming. We published an Advanced Notice of Proposed Rulemaking on that particular FMP which is very analogous to the bluefish.

It is, however, with bluefish even more appropriate from our perspective because there is a joint plan already in existence for bluefish that is identical between the Mid-Atlantic Council and the Atlantic States Marine Fisheries Commission.

So, it seems to us that to get the management closer to the people that are affected by it to put this in the hands of the states, and the Atlantic States Marine Fisheries Commission is a compilation of the states, both the state agency directors, fishermen and legislators.

Mr. PALlone. But the only thing, Mr. Matlock, is you have to go beyond and I don't know how much money would actually be saved which I guess is the purpose of these reinventing things is that you save money and maybe you can give us that information but even if it is a sizable amount and maybe you can tell me, you have to think beyond that.

The public obviously is concerned because obviously they feel that through the joint management they maybe have two opportunities to be heard and obviously there is concern because the Commission's process and I don't know exactly why, maybe some of the next panel can explain it to us, but doesn't seem to provide as much public input or at least not here in New Jersey or sufficient input.

So I guess my question is and I would like to know how much you are really saving because it doesn't seem to me that it is a lot and you have to weigh that against the fact that the public is not too happy and they feel that there is going to be less input.

Mr. SAXTON. Let me just interject before Dr. Matlock answers. This proposal has been called by some insensitive, by others unfortunate and unwise by others, a disaster and by others not beneficial to the stocks or the participants and I suspect there may be some people here with us today who feel that way.

Would you address that? If this is not going to meet with acceptance from the public that is the most concerned about this issue, it would seem to me that someone might want to take another look.

Dr. MATLOCK. Let me, if I may, try to answer the first question on cost and tell you I don't have a total dollar cost for you but I can give you some pieces to that. Currently there are about 872 commercial permits that are issued to fishermen by the Federal Government.

In the absence of a Federal FMP, and left only with the Commission's FMP, those permits and the processing of them and the burden on the public to get what amounts to two permits now would be gone so there would be an elimination of the costs associated 
with distributing those, issuing them and the people who have to get two permits.

An additional cost that would be eliminated would be the entire Federal Council process which in order to implement, for example, amendment one that has been discussed already would require from the day that it is actually prepared and submitted to the Secretary at least 140 days to get it in place.

The Commission could probably get that implemented faster than 140 days. So the ability to respond to changes in the stocks is faster under the Commission than the Commission and the Council.

So there are improvements to the system that I can't quantify for you but those efficiencies are certainly intended to be there. I will be glad to try to address then the issue of insensitivity and the other adjectives that you described. It certainly was not without a great deal of thought that the Fisheries Service has proposed the removal of this particular plan.

From our perspective with what I have just answered to $\mathrm{Mr}$. Pallone's question, it is our view that we would be making things for the resource potentially much better because the burdensome processes that now exist would be less without there being any reduction in protection that the fish could get because whether there is a Council plan or a plan done by the Commission and managed as we have proposed, the only area that we are talking about regulations affecting is in the E.E.Z. over which the Secretary has in both cases the final decision on what regulations are applicable there.

So the problems that this creates from the standpoint of what actually happens under both systems would be less with the proposal than the way we are today and that is the reason for the proposal.

So from our view we have been frankly very sensitive; sensitive to the public's concerns, sensitive to protecting the fish and sensitive to trying to reduce Federal involvement in what are predominately state matters.

Mr. PALLONE. I realize that but the problem that I see here is sort of like the framers of the Constitution with checks and balances. Why do you need a Senate and a House of Representatives?

You can get rid of one but if you do that and I guess you would speed up the process but then there would be less public input and less time to think about what is going on and why we are doing things.

So you don't convince me. I am not trying to be disrespectful but you don't convince me that by creating more efficiency that we necessarily get a better product. I would be concerned if by stepping up the process and doing everything quickly there is going to be less public input and less opportunity to maybe think about what we are doing.

Mr. SAXTON. Let me just follow up. If NMFS doesn't participate in the planning process and that the plan comes from the Atlantic States Marine Fisheries Commission then when we get into the implementation of that plan and the exclusive economic zone we would do it through the Magnuson Act or in conjunction with the Magnuson Act and then you would be involved anyway. Isn't that true? 
Dr. MATLOCK. Let me make sure that I have not misled you and indicated that NMFS and the Secretary would not be involved in the planning process. We would be. We sit on the Atlantic States Marine Fisheries Commission's boards. We participate in their meetings very heavily and Jack can give you much more detail in what we do and how we do it.

We also would be required under the Atlantic Coastal Act to consult with the Councils, the Fishery Management Councils, so they have an opportunity under the Atlantic Coastal Act to be involved in whatever it is that the Commission develops.

We also then are responsible for publishing the proposed rules and the public is provided the opportunity to comment on those proposed rules and then changes can be made to them in the final rule or even the rule is withdrawn which actually has occurred.

So I don't want to mislead you and if I have, I certainly apologize in that the Fisheries Service and the Secretary would be involved in the planning process. We would continue to be involved in it just as much frankly as we are right now.

Mr. SAXTON. What do you say? What is the advantage of withdrawing as your recommendation is from the process then?

Dr. MATLOCK. The major savings are the requirements that are placed upon us under the Magnuson Act procedurally. You have to go through a process and set timeframes for getting things published, getting them commented upon and you have to wait a certain amount of time.

Getting through that entire process for the Council and for the Atlantic States Marine Fisheries Commission means you have to do them basically twice.

So if we can do them once and get through the process to implement what the Commission and what the Secretary would agree are worthwhile things to implement we can save time procedurally.

Mr. PALLONE. Is this decision about whether to severe this joint relationship and just have the Commission, is that something that you can do on your own without Congress, is that just a regulatory change?

Dr. Matlock. Yes, sir, I believe it is. It is a regulatory change.

Mr. PALLONE. All right and what about, and again Mr. Dunnigan can tell me, this public input procedure between the two, the Commission and the Council, I guess I am more familiar with what the Council does because that is set by the Magnuson Act or at least the parameters are.

Maybe you guys can't answer it, but obviously the fishermen are concerned and the next panel, I assume, is going to get into the fact that the public input doesn't seem to be as great with the Commission. Do you want to just comment on the difference between the two in terms of public input?

Mr. GILFORD. I will ask Jack to comment on the Commission public input process but what occurs in the Council is that before we do a management plan we do a scoping document and that scoping document goes out for public comment in the sense that we go up and down the coast and have public forums where users and interested people can comment to make sure that what is considered in a development management plan covers things of their interest and concern. 
Once that scoping document comes back and there is a consensus as to the topics that should be covered in the management plan, then a draft management plan is prepared and in the process of doing that both in preceding the scoping document and preceding the development of a draft management plan there is an advisory panel for that particular fishery that is made up of fishermen from all sectors, recreational and commercial, charter boat as well so we have that input coming in.

Once the draft management plan is approved by the Council then it goes out for another public hearing to receive comment again and we have the hearings up and down the coast in all of the representative states and then it goes into the Secretary or into the National Marine Fisheries Service for final approval and eventually then to the Federal Register and again another period of public comment is available at that particular point in time and during all of the Council meetings there is public comment taken during the deliberations of the Council as well.

Mr. DunNigaN. Mr. Pallone, I think that this has been a difficult issue for the Commission to work with over the last couple of years. I think that the continuing perception that the Atlantic States Marine Fisheries Commission's process is hard for the public to get into is mainly based on some historical factors that frankly had some validity in the past. The Commission has been working very hard over the last two years to try to improve its outreach and improve its processes for bringing fishermen in to help the states make their decisions on how cooperatively to manage these resources.

The process that we follow today is very similar to what you see at the Mid-Atlantic Fishery Management Council or the South-Atlantic Fishery Management Counsel. We modeled our program after theirs. We now have advisory panels consisting of fishermen for virtually every fishery that we have under management.

The chairmen of those advisory panels constitute an overall advisory committee for the Atlantic States Marine Fisheries Commission. We have tried to place emphasis on getting those advisors to sit down with the managers and listen to the scientific information together, try to come to a mutual understanding of what needs to be done with the Fishery and we think it has been fairly successful.

If you look at amendment five to the Striped Bass Fishery Management Plan, many of the most important management measures that are contained in there came right out of our advisory process and we are in the middle right now of adopting amendment three to our Weakfish Fishery Management Plan and we are finding the same thing.

We had our advisors sitting down with our board three weeks ago in Norfolk and we will be doing it again on April 16 in Washington, D.C., and hopefully tie that up.

So we have been placing a lot of emphasis on getting our advisors to meet with our fishermen. We have the same multi-staged process of going out to the public for public hearings.

On bluefish, we are doing all of this together. At that meeting in Norfolk the Council and the Commission both had their bluefish advisors there. They had their oversight committee. We had our management board. Our public hearings have been held jointly. 
So we are developing processes. I think that this continuing problem is still a little bit of history that is coming back to haunt us. But certainly the Commissioners have been committed to trying to turn this thing around and have worked very hard over the last two years to do so and we think we are making some real progress.

Mr. SAXTON. This reminds me of the level of frustration that we get when we deal with fisheries issues very often. From a problem solvers point of view, it seems to me that it would be useful to define the problem and then to fashion a response to it.

It seems to me that we have not defined the problem very well and I am not casting the blame at anyone but we don't know why bluefish have moved offshore. At least no one has said that we have any sharp idea. Is it food? Is it the relationship between bluefish and striped bass? We don't know. Hadn't we ought to be about finding a better definition of what the problem is which would give us a better opportunity to fashion a solution to it and if that is so, then shouldn't we, Frank and I, be looking for ways to give you the tools that you need to do better science?

Mr. DUNNIGAN. I will volunteer to deal with that one first. Absolutely. There is no question about it.

Mr. SAXTON. People tell me that trawlers run up and down the E.E.Z. scooping up large numbers of bait fish. It seems to me like that is something that we ought to study. We ought to figure out if that is right. That is anecdotal information that comes to us every day almost.

Mr. DUNNIGAN. A lot of that is captured by the scientific information. Perhaps what happened in the last three months hasn't been cranked into a stock assessment yet but the scientists, to give them credit, have been looking at what the fishermen have been doing both commercial, especially commercial but also commercial and recreational, for decades.

I think it is also fair to say that they have not had an opportunity mainly because it is incredibly expensive to get out and gather all of the information that you have to study ecosystem and ecotrophic relationships to figure out just what is it about water temperatures and fish and the supply of plankton in the ocean and the relationship between bluefish and shad and striped bass.

Those are very difficult and expensive questions to try to answer but I think there isn't a scientist around who wouldn't tell you that those are important things that need to be studied and we need to find the resources to do so.

Mr. SAXTON. Anything further?

Mr. PALlONE. The only other thing that I was going to ask was I think it was Dusty who mentioned and again I am just trying to understand the difference between the public process and I think Dusty said that the Mid-Atlantic Council has more public members and not the same number with the Commission and so there seems to be a distinction at the decisionmaking level and not just the way you go about having your hearings or your public input. Would you, Jack, just maybe comment on that? Is it true that there aren't as many public members in the Commission because of the way they are set up?

Mr. DUNNIGAN. Yes. That is certainly true. The organizations are very different. We are a states organization, put together to try to 
help our state members get their jobs done. There are three Commissioners from each of our 15 states. The State Fisheries Director in this state is Bob McDowell; a legislator is Senator Lou Bassano and a public member is Tom Fote.

On our management boards each state gets to have one of its Commissioners represent that state on the board. Now the state delegations have made the decision in almost every instance that it would be the state directors.

Mr. PALLONE. So theoretically the decision level then it is strictly state directors.

Mr. DunNigan. Well, it is state by state and each delegation has come to the conclusion that they would be best served by having the state director there. Now in response to a number of criticisms even from within, from among our commissioners, we added extra seats to our management boards a couple of years ago and Mr. Fote was very instrumental in making this happen specifically to allow an extra member to represent the governor's appointees and an extra member to represent the legislators.

So we have broadened the membership a little bit and, of course, it is up to the state. They could have the governor's appointee be the member on all these boards if that is what the state delegation wanted to do.

The council system, of course, is made up very differently. There are the state directors who are there by law but there are also public members that are appointed by the Secretary who are many more than state directors.

This gets back to something that Gary Matlock was saying a little while ago about what do you achieve if you move from one system to another, is it really a dollar saving? I am not sure that that is really what ought to drive this process.

The states and the Federal Government are different and we take different perspectives on issues. The question I think for bluefish right now is whether there is an appropriate Federal perspective that is significant enough that needs to have the full Federal fisheries management process open to be used in it; or whether they should just step back and leave it up to the states.

You can't say that the two of them are just the same so that they are duplicative. Mr. Pallone is pointing out one difference in our processes that colors somehow the way we look at problems and again we don't know yet what the right answer to the proposal by the National Marine Fisheries Service is, and what we are going to recommend. Whatever they conclude I think is going to have to come from a rigorous analysis of what are the real Federal interests in this fishery and is it significant enough that we need to have the full Magnuson Act process available to be used in partnership with the states.

Mr. SAXTON. If the responsibility is passed on to the state, could the allocation breakdown be changed by the states?

Mr. DUNNIGAN. Whoever is writing the fishery management plan could do that; and remember technically it is not really an allocation. What it was was that it was a trigger.

Mr. SaXton. The $80 / 20$ is a trigger?

Mr. DUNNIGAN. Correct. In other words to maintain the traditional recreational character of this fishery it was noted at the time 
that the commercial fishery had recently at that time been about 12 to 13 percent and they wanted to allow for some growth in the commercial fishery but not too much so they picked 20 percent as a plateau and once that trigger was met then there would be a need to put a cap on the commercial fishery so that it didn't exceed that.

If it were an allocation then presumably it would work the other way, too. You would restrict their recreational fishery if the commercial fishery was ever below 20 percent and nobody ever intended to do that.

Mr. SAXTON. Let me ask you a hypothetical question. If management plans are established and implemented and enforced by the states and the state wishes to say, "Well, we think it should be $70 /$ 30 " and let's say it is Massachusetts that decides that it ought to be 70/30 and the fishermen from Massachusetts come into offshore New Jersey waters to catch bluefish and take them back and land them in Massachusetts, what kind of an effect does that have on the bluefish population? What does that do to New Jersey's management plan that may be $85 / 15$ ?

Mr. DunNigan. I think that typically what we do to our states is we focus on conservation. Our basic opinion on allocation issues is that those ought to be decided within the state if possible and if a state could show to us that whatever alternate program they had would achieve the same conservation equivalency, is what we call it, the Commission would allow the state to adopt that program to implement in its waters.

Mr. SAXTON. Now switching gears for just a minute, another example of where this would raise a concern to me, obviously we are all concerned and watching very carefully with a happy face the striped bass situation.

We all know that North Carolinians would love to go out and catch a commercial catch of stripers in the winter when they lay off the coast of North Carolina. If NMFS disappears from the striped bass management planning process, does that mean that North Carolina then would be able to go on and develop their own management plan and take commercial catches of stripers?

Mr. DunNigan. Currently North Carolina does fish commercially on that over wintering population off between Cape Henry and Cape Hatteras. They have an allocation and I am guessing but I think it is somewhere around 400,000 pounds.

Mr. SAXTON. What do they want?

Mr. Dunnigan. I think they ought to be happy with the way things are right now. That commercial allocation quadrupled this year and it will probably go up next year. So I don't know that there is any particular problem with that fishery. We have some other problems with striped bass in North Carolina but I think if the question of the E.E.Z. moratorium and, of course, none of those fish are supposed to be caught in the E.E.Z. because the E.E.Z. is closed so if the E.E.Z. moratorium were taken out, that shouldn't have any effect on the fishery.

Mr. SAXTON. Now North Carolina wants to open the E.E.Z. to commercial fishing from what I understand, is that right, on stripers? 
Mr. Dunnigan. The State of North Carolina, the division of Marine Fisheries? I am not sure.

Mr. SAXTON. There was a proposal a few months ago which would have opened commercial fishing in the E.E.Z. and my understanding was that it would have been most beneficial to the commercial fishermen out of North Carolina.

Mr. Dunnigan. You held this hearing in Washington, D.C., a couple of months ago.

Mr. SAXTON. That's correct.

Mr. DunNigan. North Carolina commercial fishermen by in large supported that proposal by the National Marine Fisheries Service to lift the moratorium, that's true.

Mr. SAXTON. Right. Now my question is this. If we extrapolate the proposal of NMFS to striped bass, will the State of North Carolina have the ability to open to commercial fishing the striped bass fishery in the E.E.Z. if this same type of proposal is taken to the striped bass fishery?

Mr. Dunnigan. Mr. Chairman, under the Commission's Fishery Management Plan, the North Carolina quota for that fishery would stay the same. It is just a question of where the fish would be taken, whether they would be taken inside of three miles or outside. Whatever their quota was for that fishery under the plan, it would stay the same.

Mr. SAXTON. But in either case, the states would have the authority to develop their own management plan independent of the Federal Government's desires to have them conserve if that may be the case.

In the first example that I used, the State of Massachusetts might develop a different ratio of take between commercial and recreational fishermen, is that right?

Mr. DUNNIGAN. Yes, sir.

Mr. SAXTON. And there is nothing to prevent the fishermen from coming into offshore New Jersey waters?

Mr. Dunnigan. Presumably that would be allowed unless in this case and we are really speculating here, the Commission's Fishery Management Plan denied that flexibility to a state. The Commission could do that but it has not.

Mr. SAXTON. So there really is a significant difference between a regime that manages the fish for the east coast through the Federal Government and the regime that manages fish on a state-bystate basis?

Mr. DUNNIGAN. I think there could be those differences, yes, and I think whether or not we believe those are significant enough in bluefish to justify the continuation of full participation by the Federal Government under the Magnuson Act is the issue that we have to decide.

Mr. SAXTON. Thank you very much. We have been at this for I guess a good hour and a half and we appreciate your participation today. We would ask that the record remain open for written questions should we have any and once again, thank you for your participation. We look forward to working with you in the future.

Before we call our second panel, we are going to take a short break and then we will be right back for some good input from some local people. 
[Recess taken.]

Mr. SAXton. We are ready to go on here with our second panel. Our second panel consists of our good friend, Tom Fote who is President of the Jersey Coast Anglers Association, Big Wheel but not president; Mr. Ray Bogan from the United Boatmen of New Jersey and New York; Mr. Gil Radonski from the American Sportfishing Association, and Karter Larson of Barnegat Light recently finished his tour of duty in the Armed Service, and I want to say Navy.

Mr. LARSON. Air Force.

Mr. SAXTON. In the United States Air Force, and part of the family operation which takes place commercial fishing out of Barnegat Light, commercial meaning headboat and other, yes?

Mr. LARSON. Mostly commercial.

Mr. Saxton. Mostly commercial. So Mr. Fote, if you would like to start. During the break somebody came up to me and said there were lots of bluefish along the coast until the bunker boats took all the bunker and the bluefish were left without food. Please comment on that among the other things that you decided are important to say to us. Please go ahead.

\section{STATEMENT OF TOM FOTE, JERSEY COAST ANGLERS ASSOCLATION}

Mr. Fote. You will have to indulge me a little bit, I have a bad cold and my voice might be a little quiet today. The Jersey Coast Anglers Association would like to thank Congressman James Saxton for holding this field hearing on bluefish in Toms River and Congressman Frank Pallone for attending this hearing. JCAA is aware that both Congressmen understand the importance of bluefish for the citizens of New Jersey.

Do bluefish play an important role in the fisheries industry of New Jersey? Absolutely yes. Just look at the statistics and you will understand that bluefish are important to the recreational and commercial fishing industries.

Most salt water anglers, as children made their first catch on snapper blues. They were abundant, easy to catch and provided an immediate, positive reward for the child's' effort. Tackle store owners know that fishing for bluefish creates business for them.

The nature of bluefishing creates the need for new lures and new tackle. Bluefish can empty an anglers' tacklebox faster than any other species. It may be frustrating to the anglers but it is certainly good for business.

In the 60's, 70's and 80's, bluefishing was the bread and butter experience for the party, charter and private boat owners as well as surf fishermen. Companies such as Ultimus Lures got their start making bluefish lures. I often spent September, October and sunny November days on my boat chasing bluefish.

With the decline of the bluefish stocks in New Jersey, these industries, tackle shops, tackle manufacturers, party and charter boats and marinas, have suffered economically. No other species has filled that gap. As the bluefish declined, so did these industries.

Having expressed my concern about the economic impact of the decline in the bluefish stock, let me now address the questions sub- 
mitted. What is responsible for the decline in bluefish stocks? There does not seem to be a simple answer.

For some species, overfishing or a loss of habitat are clearly the reasons for the decline in the stocks. This does not seem to hold true for bluefish. The commercial fishery has remained constant since the 60's.

There has been no dramatic increase in the commercial fishery to blame for the decline in the bluefish stocks. The recreational anglers dramatically increased their catch in the 60's with no restrictions and had no measurable effect on the stocks.

The ten fish bag limit imposed in the early 1990's did nothing to stop the collapse of the stocks. The bag limit was not imposed to preserve the stocks but implemented as a poorly conceived conservation measure.

The dramatic collapse of the stocks followed rather than preceded the bag limit. I am not a scientist but I have been involved in fisheries for a long time. It takes no scientific training to realize as forage fish that feed the bluefish stock decline, the bluefish will soon decline as well.

From the 60 's to the 80 's sand eels were in abundance, especially in the New York Bight. I could go out Barnegat Inlet and travel to Manasquan Inlet and constantly record sand eels on my chart recorder. This is no longer true.

The discovery of an isolated pod of sand eels is the exception rather than the rule. These sand ells provided the fattening need for the bluefish fall migration. Today's bluefish are described as runners, long and slender with little of the usual body fat.

As a response to stress, many species decrease their reproduction. No wonder the stocks of bluefish are declining. We have theories but no definite explanation for the decreased in forage stocks.

Until the forage stocks increase and the conditions improve, we must implement a management plan to insure that the spawning stock biomass of bluefish is large enough to rebuild the stocks. The heyday of the 80's may never return but we cannot allow the stocks to fall beyond the point of recovery.

What will be the impact of eliminating the Mid-Atlantic Council from the management of bluefish? The elimination of the Mid-Atlantic Council from bluefish management would be a disaster. Public input would be curtailed severely.

By comparing the records of the Mid-Atlantic Council and the Atlantic States Marine Fisheries Commission, we can clearly see that the Mid-Atlantic Council affords the citizens of New Jersey with much more access and more ability to participate in the decisionmaking process.

Last year, the Mid-Atlantic Council held two meetings in New Jersey, in Atlantic City and Long Branch. The Atlantic States Fisheries Commission has not held a meeting in New Jersey since 1988.

This year's scheduled meeting in Philadelphia was relocated to Norfolk, Virginia. Until the Atlantic States Marine Fisheries Commission revises its meeting schedule to provide access to all states and their citizens, then we need the Mid-Atlantic Council to fill in the gaps and insure public participation.

How should the Bluefish Management Plan be amended? We need to insure the historical split of this fishery. During the 80 's 
the recreational sector made up over 92 percent of the catch. The current management plan calls for an $80 / 20$ split.

In practice the split has not been holding at $80 / 20$ and we must manage bluefish the same way we manage fluke. We need to rely on the scientists to determine the bottom line figure for bluefish stocks so we do not slide below that figure while waiting for conditions to change.

Both the commercial and recreational communities need to share the burden in a way that reflects their historical catch. We also need to consider if it is to our advantage to slow the harvest in the short-term, hoping for a long-term increase or a longer sustainable yield of bluefish.

Science does not currently provide data to make a definitive decision. A full moratorium might not substantially increase the stocks at this time. Or, for that matter, not slow the decrease but it would cause economic disaster for the fishing industry.

Any plan that will come from the Mid-Atlantic Council and the Atlantic States Marine Fisheries Commission must do two things, insure that we preserve a spawning stock biomass large enough to rebuild the stocks if the conditions are right, and protect the historic commercial/recreational split. Each community should share fairly in any sacrifice that must be made.

Remember, the original Bluefish Management Plan was not designed to address a declining stock. It was written to protect the historical split from any new fisheries that might develop. The great fear was that any new foreign markets could devastate the stock. Any new plan must be based on different assumptions that recognize the current decline in the stock. Thank you.

Mr. SAXTON. Thank you, Mr. Fote. Mr. Bogan.

\section{STATEMENT OF RAYMOND D. BOGAN, UNITED BOATMEN OF NEW JERSEY AND NEW YORK}

Mr. Bogan. Thank you, Mr. Chairman, and thank you Mr. Pallone for the opportunity to testify. I am Ray Bogan and I represent the United Boatman of New Jersey and New York which is an organization of charter and head boat owners and operators.

Our members own and operate some of the largest vessels and businesses in the head boat and charter boat industry on the east coast. We literally traverse hundreds of thousands of miles of ocean in the course of a given year. In that regard, I would like to testify as to the role of the Federal Government in the management of bluefish. As I go on, I will also discuss the proposed change of rule which would give the Atlantic States Marine Fishery Commission primary jurisdiction over fish management.

To begin with, I would like to say, do we believe there is a decline in the biomass of biomass? Yes, we feel there is some decline. However, what we would like to strongly indicate is that before we conclude the extent of the decline, or before we conclude that this decline is precipitous, we have to look at an awful lot of factors and that is the basis of my testimony today.

Since the late 1980 's, there have been significant changes in bait patterns and availability. Indeed, prior testimony made reference to a change in sand eel abundance. My family ran, I believe, the only sand eel bait boat in the states of New Jersey and New York. 
We were major suppliers of sand eels to recreational bait purveyors.

I can tell you firsthand that the boat stopped sand eeling as of four or five years ago after four to five years of unsuccessful sand eel fishing. It was because of a major shift in this forage fishery. It is one of the most significant bait shifts that we have seen in the course of 60 to 70 years, which is how long my family has been involved in this fishery.

Again, the one bait boat in the two states that had to stop fishing for sand eels-a major, major circumstance. Sand eels are not the only primary forage fish which have changed. We have seen other changes in patterns, such as river herring, bunker, et cetera.

The striper issue, when we talk about predation, we are not talking about predation on juvenile bluefish. I heard that referred to in the prior panel. That is not the problem. Stripers are one of the only fish in the Atlantic Ocean which can compete with bluefish as predators. Thus, we do not contend that they are eating the significant numbers of young of the year of bluefish-although they do that obviously. The major concern is that they compete for the same bait fish.

While we observe decreases in bait fish, greater predation on the part of a competitor for the same bait fish, what we see simultaneously is a significant shift of bluefish to the offshore.

We have more boats to fish offshore waters than just about any single organization on the east coast. These engage primarily in fisheries in the canyon and offshore wreck fishing. What have we seen consistently? We have seen offshore wrecks overrun with bluefish, literally to the point where boats move away from wrecks because they can't fish there for their target species.

My family is the holder of four to five groundfish world's records. We have fished offshore wrecks for years and years and we have not seen this type of offshore invasion of bluefish for decades.

With regard to the shifts in water temperature, I would like to comment on the Stoneybrook study which is now being undertaken. To date the study finds that there is no definitive conclusion that can be reached. Let me point out two things.

First of all, we have seen in the last eight to ten years a significant infusion of Spanish mackerel, dolphin and other semi-tropical game fish into the New York Bight. If there is not a change, if those patterns have not deviated, then why is there an historical occasion occurring with the infusion of these fisheries in northern waters?

The basis of this question may appear anecdotal but it raises a question that fisheries' managers, because of restrictions in financing for research, et cetera, just haven't addressed. Therefore, they say since we can't address it, let's disregard it. This is improper. It is absolutely improper to disregard these factors when trying to determine the status of stocks.

With regard to anecdotal information, our fishermen have attempted over the years to provide to the scientific community anecdotal information. There are instances that can be readily cited which demonstrate that our anecdotal information was more accurate than the scientific information which you heard today and for other fisheries. 
For example, bluefin stock assessment was examined through a scientific peer review, it was demonstrated that anecdotal information in very integral parts of the stock assessment was more accurate than was the quote/unquote scientific information. Another example is catch data for angling category bluefin tuna. Catch data preliminaries showed that recreational catches were 200 percent over quota according to NMFS data obtained through MRFSS survey and LPS. We stated that it was wrong. We tried to support our position by submitting anecdotal information. NMFS engaged in a peer review and again, by no coincidence, we have been proven to be correct.

Yellowfin tuna reports indicated significant underages in catch estimates. We have taken a ten-fold increase in our catches as a result of anecdotal information. There is merit to anecdotal information. It is now largely disregarded in the process and it can't be any longer.

With regard to the ASMFC taking over primary jurisdiction bluefish management, I don't know that I was the one who could have said that it was a disastrous idea, but I wish I had been because that is how I consider it.

I think it is very dangerous. To me, it is an attempt to circumvent the restrictions of Magnuson. The very process of Magnuson, the 140 day regulatory process that Gary Matlock referred to, that 140 days was included in the Act for a reason. Congress determined it was necessary. Right now NMFS is suggesting, as to the bluefish, well why don't we get rid of it, why don't we streamline it. We can't do that.

The ASMFC is an entity, in three different instances, which has totally disregarded the public process. The very technical advisors that you folks have been told about were disregarded. Indeed, in certain instances they have been left out of the room where decisions have been made.

Gary Caputi pointed it out on striped bass. The technical advisors were put out of the room during the decisionmaking process. On bluefish, it was a committee, and not the full commission, that voted on a three-fish limit. Only because of great political pressure was this vote overturned.

Then finally on striped bass, Congressman Saxton you have put in a bill to try to restrict the fishery in the E.E.Z. until we know more of its potential impact. Guess what, the ASMFC is going back to revisit it.

The public process is not part of the ASMFC's vocabulary. I cannot emphasize enough what a bad idea this proposal is until ASMFC is made accountable to the public and allows the public into the process. The Coastal Fisheries legislation has to be amended, as does the charter of the ASMFC, which right now does restrict the public imput.

One final thing. With regard to amendment one to the Bluefish Fishery Management Plan, it provides an excellent opportunity. It is necessary. It is also an opportunity to incorporate that very information, and the very same anecdotal information, that I have made reference to which managers try so hard to stay away from.

There is information out there. It is biological information. There are shifts in bait. There are shifts in water. There are shifts in the 
biomass. Why? We don't know. Please let me just point out one thing with regard to the chart attached to my testimony.

Please look at this NMFS' data with regard to a 50 year running average on bluefish. You will recognize that stock collapse occurred one time, and one time only, around the time of World War II.

Does that call into question the issue of what fishing effort has done to the condition of stock? It certainly does. If there was a stock collapse, when theoretically there was much less fishing effort, something is wrong. By the way there was another significant decline right around 1924 and 1925.

Unless we reexamine the year base, unless we get a better idea of the dynamics of this fishery, any management plan including the amendment will be deficient. We respectfully hope that the Commission/Council system and, ultimately, the overseers of those systems, those being you, consider that there are other factors that have to be incorporated. Thank you.

[The prepared statement of Ray Bogan may be found at end of hearing.]

Mr. SAXTON. Thank you. Mr. Radonski.

\section{STATEMENT OF GILBERT C. RADONSKI, AMERICAN SPORTFISHING ASSOCIATION}

Mr. RADONSKI. Thank you, Mr. Chairman. I am Gil Radonski and I am here representing the American Sportfishing Association. The American Sportfishing Association is a trade association made up of 700 member companies which supply recreational fishermen a broad array of fishing equipment. We are made up of manufacturers, retailers, wholesalers, advocacy groups and state and Federal fishery agencies.

I will not go through my entire statement, just hit on the high points. You have broken this down into three general areas, with the status of the bluefish stocks as the central focus. If we are looking for a smoking gun on what is wrong with the bluefish stocks, it is easily found. It happens to be a double-barreled shotgun. Both barrels, pulled at the same time, are overfishing and the cyclic nature of bluefish.

The only question now is how far can we let overfishing, or continued over exploitation, continue to drive the stocks lower, how low can we safely let them go and still have a chance to rebound. That topic was briefly addressed in the last panel.

I am a strong proponent of using scientific information in fisheries management. What we tend to argue about is the precision of that information. We have been looking mostly at the nature of trends in fisheries.

We do have real-time data gaps. We don't have the money to get the scope of data needed for the management that a lot of people are looking for.

The second area of concern is the shift of authority from the MidAtlantic Council to the ASMFC. My organization favors the MidAtlantic Council abandoning the Bluefish Plan not for the reasons given, efficiency in government or reduction in paperwork, but to have a focal point for the management of fisheries, in this case, bluefish. 
It was earlier stated that the Bluefish Plan is a joint plan, written in 1989. I would submit that the ASMFC that participated in the plan in 1989 is far different than the Atlantic States Marine Fisheries Commission of today.

Today they are armed with a new Act, the Atlantic Coastal Fisheries Cooperative Management Act. They have more resources and although not perfect, they are getting better. Rather than focus on turf at this hearing, whether we go with the ASMFC or the MidAtlantic Council, let's select an agency that can efficiently manage this fishery. It is predominately a territorial sea fishery, both commercial and recreational.

For that reason I think that the ASMFC is the proper place for bluefish management. I think we need to look at a real problem that this subcommittee can address. It is developing a protocol for the interaction between the Magnuson Act and the Atlantic Coastal Fisheries Cooperative Management Act.

That protocol must involve all three councils on the east coast, the South Atlantic, the Mid-Atlantic and New England. They have to get together and develop procedures where they can straighten some of these problems out and get the efficiency in fishery management that we need.

The third area of concern is what needs to be done to the bluefish fishery management plan. When the plan was written in 1989 it was fatally flawed. It was a horrible plan. It was written and highly touted by the Mid-Atlantic Council as a plan that was written for a fishery that is not in trouble. Well, the fishery went down.

It wasn't because of the Council's plan, I don't mean to imply that in any form or fashion. It was the cyclic nature of the fishery and over fishing.

The plan has no conservation provisions and the allocation procedure is wrong. The plan equates recreational catch to commercial landings. It punishes recreational fishermen for releasing their fish. It is a terribly flawed plan and we support going back to the more historic levels of an $85 / 15$ split between recreational/commercial fisheries.

Many statements here have been made about the steady level of the commercial catch. There is a reason for that. It is not the abundance of bluefish fishery that gives that the stability. It is the price of bluefish. Bluefish are not highly sought after as table fish.

In 1993, the last year that NMFS published a Fisheries of the USA, the average price for bluefish landed, I think, was around 37 cents per pound and that is pretty low. When you look at the recreational fishery, since the mid-1980's the average catch of a recreational fisherman has gone from over three pounds per trip to less than a pound per trip. If you look at the cost, that pound of bluefish will get you about 37 to 40 cents on the market. The average fisherman catching a pound spends about $\$ 76$ on a fishing trip.

We need to have programs that will lead to rebuilding of the stocks and if it is more efficiently done through the ASMFC, a single agency, we believe that is the way to go. I hope that this Committee will not get locked into a turf battle but look at efficient solutions so we can start rebuilding stocks. 
One final point, when we do get Amendment One to the Bluefish Plan it probably will not go into effect until the 1998 fishing season. That is another inefficiency of the Magnuson Act.

If the Council does not have Amendment One in place by at least July of this year, then the provisions will not be put in place until the 1998 fishing season: It can be done faster through the ASMFC.

When a rebuilding schedule for bluefish is developed, we have got to stay the course. We can't say that we are going to rebuild in five years and then if we have one good year class increase the catch and spread the schedule out to ten years. We have done this in other fisheries. We should not do it with bluefish.

I think I will let it go there, Mr. Chairman, so we can get to the questions. Thank you for asking me to testify.

[The prepared statement of Gilbert Radonski may be found at end of hearing.]

Mr. SAXTON. Thank you very much. Mr. Larson.

\section{STATEMENT OF KARTER LARSON, BARNEGAT LIGHT, NEW JERSEY, ON BEHALF OF KEVIN WARK}

Mr. LARSON. I am Karter Larson and I am speaking on behalf of Kevin Wark who apologizes for not making it today. He is fishing and trying to make a living but I am going to read his statement verbatim.

"Chairman Saxton and members of the Subcommittee on Fisheries, Wildlife and Oceans, thank you for holding this hearing to consider one of New Jersey's most important fisheries, for your continuing interest in all of New Jersey's living marine resources and for your support of New Jersey's working fishermen, recreational fishermen and the multi-million dollar industries that they all support.

"My name is Kevin Wark. I am a commercial fisherman and a resident of Barnegat Light, New Jersey. I have owned and operated my own boat, the F/V Endeavor, for ten years and have worked on other boats for five years previously.

"My boat is a gillnetter and for most of the year I fish out of the Viking Village dock in Barnegat Light, primarily for weakfish, shad, bluefish and monkfish. I am a member of the Atlantic States Marine Fisheries Commission's shad and bluefish advisory committees, the Joint Mid-Atlantic/New England Fisheries Management Council's monkfish advisory committee and several New Jersey Marine Fisheries Council advisory committees. I am also a member of the New Jersey Commercial Fishing Congress." He is a busy man.

"As you are well aware, Barnegat Light is an important commercial and recreational fishing port. My boat is one of a fleet of gillnetters based there that for part of the year specialize in bluefish.

"By providing the freshest, highest quality product and capitalizing on a very successful marketing effort by the people at Viking Village, we have developed a demand for premium Barnegat Light bluefish.

"Through participating in this fishery over the years, through my contacts with other fishermen working the inshore and offshore waters of the Mid-Atlantic, and through following and then participat- 
ing in the management process I have developed a certain level of familiarity with and knowledge of the bluefish fishery.

"Based on my own observations and on discussions with other recreational and commercial fishermen, I can't say that I have seen or heard of any indications that bluefish have become less plentiful over the past several years.

"My reasons for this are, in the recent summers there have been lots of small bluefish in Barnegat Bay and the other coastal waters that I am familiar with. We have been seeing average to above average numbers of medium and large bluefish in the ocean in the areas that we normally fish. Last year there were large numbers of five to ten pound bluefish in the waters from ten to 20 miles offshore for the entire summer.

"The headboats were catching these fish steadily and their passengers regularly filled their ten fish bag limits. Making allowances for management imposed closures, our bluefish landings have been consistent with the effort we have been putting into the fishery. We have not had to fish harder to produce the same amount of fish.

"The feeling that the bluefish stocks are declining that is being expressed by some managers and recreational fishermen and that is part of the reason for this hearing today, might be due to another phenomena that seems increasingly plausible; the bluefish stocks aren't declining but the entire population is moving either north and east or farther offshore.

"In support of this, Longliners report seeing tremendous schools of bluefish up to 50 miles offshore. Tilefish boats see large bluefish schools in the offshore canyons in the spring and bluefish can be so prevalent 30 to 50 miles offshore in the summer that they interfere with shark fishing.

"For over five years we have been hearing of recreational anglers regularly catching bluefish in waters as far outside their normal range as the Gulf of Maine and that this is out of the ordinary is indicated by the fact that in his 1974 book Successful Bluefishing, author Hal Lyman states, 'In the 1950's and again in the late summer and early autumn of 1971, blues were abundant as far north as Old Orchard Beach, Maine.'

"Bluefish moving from their normal areas of concentration could be due to changes in water temperature or currents or to competition from other species such as striped bass, another highly effective predator that is found in the same areas and feeds on many of the same forage species.

"Coupled with a possible shift in range might be a decline in recreational bluefish landings caused by shifts in recreational fishing effort. Over the past five years both fluke and striped bass have increased in abundance in the Mid-Atlantic. Prior to this, many recreational anglers focused on bluefish for no other reason than that they were the only fish available for harvesting.

"Now, with the return of the more desirable fluke and stripers, the recreational effort targeting bluefish must have declined significantly. In recent years there has also been a significant increase in the number of smaller recreational boats going offshore in search of tuna and, to a lesser extent, billfish. Before this fishery developed most of this effort was probably expended on bluefish. 
"Added to these changing recreational fishing patterns, a first time bluefish bag limit was imposed in this same period. Considering all of this, it is hard to imagine how recreational landings wouldn't show a significant decline regardless of the number of bluefish in the ocean.

"More than anything else the bluefish situation emphasizes the flaws in our system of estimating the size and health of fish stocks. This system has become much too dependent on what recreational and commercial fisherman are catching or on what the statisticians estimate we are catching and much too separated from any actual sampling of the number of fish in the ocean.

"What fishermen catch isn't always the best indicator of the health of a fishery. Landings are too often dependent on fisheryindependent factors. The bluefish not being where they usually are or as thick as they used to be doesn't necessarily mean there are too few of them out there and shouldn't be used to justify further management restrictions.

"All of us that are seriously involved in fisheries management are becoming increasingly aware of the increasing use of pressure to force the management system to allocate fisheries resources between user groups, often to the detriment of a particular group of users and with no benefit to the fisheries being managed.

"I hope that this won't be the case with bluefish. Meetings that I have participated in lead me to believe that it won't be. One of the major problems with bluefish management up until now has been the indexing of the allowable commercial harvest to the recreational harvest.

"We appear to be moving away from that, considering independent recreational and commercial 'total allowable catches' for each sector instead and this is a step away from an allocation driven system.

"If, as many of us suppose, the bluefish stocks are healthy it is possible to manage them to allow for greater utilization. Particularly considering the pressure on many of our other fisheries, if this could be done without threatening the sustainability of the fishery it should be seriously considered.

"Finally, I would like to address the proposal to have all bluefish management authority taken from the Mid-Atlantic Council. Speaking for myself and this is a feeling that is shared by the majority of recreational and commercial fishermen that I deal with, one of the greatest strengths of the Regional Council system is the public accessibility that is designed into it.

"Taking the Council out of bluefish management will effectively bar many of the users, both recreational and commercial, from participating in bluefish management. By holding this hearing today you are showing us how important you think public participation is. Please help us to maintain this level of participation by keeping the Mid-Atlantic Council actively involved in bluefish management.

"In support of the idea that the bluefish stocks are not being depleted, I have included a page of charts prepared from MRFSS data looking at the age distribution of recreationally landed bluefish from 1982 to 1994 . These charts indicate a population surprisingly constant in age composition, something that doesn't seem consistent with any kind of excessive fishing mortality. 
"Thank you again for your concern with a fishery that is important to millions of consumers as well as the thousands of commercial and recreational fishermen in New Jersey."

Mr. SAXTON. Thank you. We are once again going to be informal and inasmuch as I started the last round of questioning, I will yield to my colleague to start this round of questioning.

Mr. PAllone. Thank you, Mr. Chairman. I wanted to ask Tom, you said in your testimony that the bag limit that we are living with now was not originally proposed to address, and I don't know if you said the decline in the fishery or the issue of overfishing, what do you mean by that? What was the intent?

Mr. FoTE. Well, I am going to refresh the Congressman's memory. When you had the Chairman of the Mid-Atlantic Council at the time before this Committee, the Fisheries Committee, and they asked him why you are putting a ten-fish bag limit on bluefish, he said because you throw them in dipsy dumpers and you throw them in the garbage and that is the only reason that you put that ten-fish bag limit in place. It had nothing to do with conservation.

Mr. PAllone. So it wasn't actually down at a time when the stocks were declining.

Mr. Fote. No. When the plan was basically being implemented there was great fear and $\mathrm{Al}$ Ristori is sitting in the audience here and $\mathrm{Al}$ was responsible and so was Bill Feinberg.

Mr. RADONSKI. I remember now. It is a long time ago but I remember.

Mr. FOTE. But basically the bluefish management plan was basically designed that if a foreign market developed large processing ships could not come into the fishery, basically destroy the stocks and effect both the historical commercial and recreational sector because the commercial fisheries insure gillnet fishery and large processors could basically put the Kevin Warks out of business.

That is what the bluefish management plan was designed to do and when that plan originally went up, there was no bag limit but when NMFS in its infinite wisdom said that unless you put a bag limit we are not going to pass the plan and that is how we got a bag limit on it.

Mr. PALlONE. And that is how many years ago now?

Mr. Fote. The plan was passed in 1989. At the time and Ray and I, I think, are both in total agreement that when they passed the plan, I said it was the worst plan I ever saw. I still agree that it was the worst plan.

It really didn't address the problems. It didn't address the declining stock and it basically just looked good on paper. They said they were going to do something on the stock before it started to decline. Because we asked the question and you asked someone at the hearing and Congressman Saxton:was at the same hearing with Jim McQue and Jim has passed away since, are there any problem with the stocks and both of them said no. We are just doing this because you are basically throwing them in dipsy dumpsters. That is water under the bridge.

There is a problem with the stocks. The stocks are not where they were in the 1980's. The 1980's might have been an all time high period. We might not be able ever to obtain that. What we 
have to look at is a necessary spawning stock biomass that will reproduce.

The question you asked before, where do we need to keep that stock, really you haven't come up with that figure. Do we need 1,000 fish to reproduce 100,000 if the conditions are right or do we 2,000 fish and when we establish that then we can establish what the spawning stock biomass is necessary.

Mr. PALlONE. Ray, when you gave us that chart that showed the declines, I guess in the 1940's and also in the 1920's, has there ever been any analysis of these stocks declined significantly then?

Mr. Bogan. None whatsoever. As a matter of fact this study was a 1977 NMFS study that included information up to 1974 or 1975. They frankly didn't even address the fact that there were those massive declines. It certainly wasn't because of the fishing efficiency of the commercial sector, for example, because if that were the case then you wouldn't have had nine million pounds in the 1930's. It was an instance in which the fish disappeared.

Mr. PALLONE. There was a dramatic increase.

Mr. BOGAN. Extraordinary. We have never seen anything like it, and certainly no one would ever argue that this is anything near what that was. Nobody could, even the most rabid proponent of restrictions on bluefish.

Mr. PALlONE. It would seem to me that that data would basically go along with the theory that declines or increases are not based on overfishing just because it is so dramatic. There is no reason to believe that there was any overfishing.

Mr. BOGAN. I think Gil raises a very good question. If we are all conceding, and this was not easy but is as a result of this hearing, we are now conceding that, OK, the decline in availability really is cyclical. Three months ago you would not have that concession on the part of certain of the people who I have heard today.

Now that that is being conceded, the next question is OK, it is cyclical, however is it fishing effort which is driving it down? Well, there is decreased fishing effort. You have a ten fish limit which results, it is acknowledged, in number one, a decrease in the ability to catch more fish than ten but number two, it also results in decreased effort.

Thirdly, there are developing offshore fisheries which, although they go up and down, they certainly have increased during that time. Theoretically, right now we are in a significant down cycle in terms of fishing effort for bluefish. Stocks aren't coming up. Does that not tell us that a three fish limit will have very little positive impact. The only impact it will definitely have is to destroy a sector of the industry which is extraordinarily important.

Mr. SAXTON. Excuse me, if I may break in Frank, what are you saying about cycles? You mentioned the word cycle earlier in your comment just previously.

Mr. BOGAN. I think it is pretty much acknowledged now that this is a cyclical situation that we are dealing with and Gil raises a question which I think we all have to ask and that is, what is the impact of our effort upon the cycles? If we look at history it would suggest that we better be very careful before we make very, very significant restrictions. This is what has been tried to be put 
through by the ASMFC in a vote which, by the way, totally disregarded the public process.

Mr. SAXTON. Let me just make sure that we explore this point to the extent possible. You would agree then there is a book that has been written by a gentleman by the name of John Hersey who published the book in 1987 and it is called "Blues" and he notes that boom and bust cycles have been observed in Atlantic Coast bluefish since pre-Revolutionary times and that those cycles run opposite to those observed in striped bass.

Mr. BOGAN. That's correct.

Mr. SAXTON. Would you agree with that sentence?

Mr. Bogan. Absolutely, and I think it is proven. We only have data that is scientifically verifiable as of, I think it is 1918 or 1919 , somewhere around there, where it is verifiable and those cycles are confirmed.

As to the striped bass issue, again, I want to emphasize that our opinion is that we do not believe that the striped bass situation is as much them preying upon juvenile bluefish, even though that is obviously a significant factor, but what we think is most significant is the competition for the bait source. The only fish that you can think of that is half as voracious for its size to a bluefish is a striped bass and our folks who have for years been on the sea have seen this.

Mr. SAXTON. Let me see if we can get the opposite side of this. Gil, would you like to address this? You are an advocate of greater controls vis-a-vis recreational and commercial fishing, is that true?

Mr. RADONSKI. Well, not quite. I am for rebuilding the stocks and I felt for a long time that bluefish are cyclical. I think it is almost impossible to deny that fact. My question is how far are we going to push that cycle and still get a recovery. Overfishing is a factor. We have tremendous pressure.

I made a comment before about the commercial catch being rather stable. It has declined somewhat because of the quotas, the numbers have gone down. When I was on the Mid-Atlantic Council the commercial fishing industry came before us and testified that there is a very minuscule amount of directed fishery for bluefish. The bluefish commercial catch is largely an indirect catch. They are fishing for other species and catch bluefish.

The reason that it has remained fairly stable is because you can overload the market very quickly and drive down the price to the point that it is not even worth bringing the bluefish in. So, you can't look at the commercial catch being flat as an indication of abundance. It is a condition of market and market price.

That is what drives the bluefish commercial catch and I would like to see the allocation process changed from the present system where it is based on recreational catch, that triggers the commercial quota, to one of fishing mortality. It would still be an allocation, you can't get away from allocation, it is allocation based on historical harvest levels and would be based on mortality not catch.

For example, I mentioned that recreational fishermen are punished for conservation. That is because up until this year when they revised it downward, they assumed that 30 percent of all bluefish caught and released by recreational fishermen would die. They 
revised it downward recently to 15 percent and tacked that on to the fishing mortality for recreational fisheries.

The only basis for the commercial quota is on landings. There is no consideration of fish dumped overboard or killed in other fishing operations, shrimp trawls, whatever, it is just pure landings. It is a totally antiquated way of doing things, totally unfair, and will not solve the problem.

Mr. SAXTON. Let me interrupt you for just one minute. I don't know this aspect but let me ask Karter, do commercial fishermen have a directed fishery on bluefish today?

Mr. LARSON. There is a point in the summertime where they go out for bluefish but like you said if price drives everything, there is no reason to catch them. If they are not going to make a living doing it, they are not going to. However, if they do make a good living catching bluefish.

Mr. SAXTON. Do they make a living at 37-cents per pound.

Mr. LARSON. That doesn't sound very good to me.

Mr. SAXTON. It doesn't sound very good to me either. I just can't imagine firing up your boat for 37 cents a pound.

Mr. LARSON. If you are going to go low price, then it is going to be high volume like the dogfish.

Mr. SAXTON. So what do you do with high volume bluefish? What is the market?

Mr. LARSON. Low.

Mr. SAXTON. Supermarkets, human consumption, cat food, processors?

Mr. LARSON. I don't know. It is my favorite fish so I always eat it.

Mr. SaXton. Yes, Tom.

Mr. Fote. Just to follow-up, in our state there has been always a directed fishery for bluefish on a small scale because of the market as a whole, Point Pleasant Co-op, Barnegat Light, and they basically will direct at certain periods of time because they can get a good price.

What you find up in other areas like in Maine where people don't want to eat bluefish, they go for bait for other things like lobster bait which has been discussed in the Atlantic States Marine Fisheries Commission and we need to find out how much is going for lobster bait. Those parts of the fishery are there.

But here you usually get a good price and at 37 cents per pound if you can make a big enough catch and the market will bear it and give you 37 cents, if you are just running out of Barnegat Light and netting on Long Island Beach State Park, that will make a good pay day for you and so yes, it is important to the commercial fisherman and the recreational fisherman. They need that fish. It is needed to provide an income in this area.

We talk about the stocks going up and down and whether it is cyclical or not. I listen to striped bass being blamed for a lot of things and I think of the story I was reading about the Potomac River and where we had 427 million river herring caught one year, something like 27 million shad and the average for the whole thing was 450 striped bass at the average weight of 60 pounds and that was 1832 . By the 1900's we had to build all those hatcheries. They 
all got along fine together before man started interfering with the stocks.

If you look at the 1960's and '70's, striped bass went all the way up at the same time bluefish were going up. It is in the 70's when they collapsed, when you were basically throwing all nets across the Chesapeake Bay.

Mr. SAXTON. Let's explore another aspect which has been discussed several times and that is that perhaps the fish stocks have moved offshore. I went tuna fishing, I think it was last summer and unfortunately a strong west wind came up and we got about 20 miles out. We decided that we didn't want to go where the tuna fish were because it would take too long to get back and some of us were already feeling the effects of the heavy seas.

So we stopped and began to catch bluefish and you put your line in the water and you would have a bluefish on it. We have also heard anecdotes today of bluefish on wrecks and unusually large numbers of shark fishermen that have a difficult time fishing for shark apparently because there are so many bluefish around that it. This makes it, for some reason, difficult to catch shark. We have heard of bluefish being found offshore in areas where they are not historically found.

I guess a case can be made that the stock offshore and when we begin to try to scientifically measure it, it seems to me that it is a whole different thing trying to scientifically measure bluefish stock as opposed to stripers when you can go down to the Chesapeake in the Choptank River and do a population count. You know what the new stock looks like and you know what the numbers are but you can't measure bluefish stock for obvious reasons.

They spawn offshore and have their young so it is very difficult to measure the stock. I guess on the one hand we have scientifically less accurate information and on the other hand there is at least a whole bunch of anecdotal evidence that there is a significant stock offshore, whether it is large or small, and let's talk about this for a minute. Ray.

Mr. BOGAN. A comment with regard to that offshore fishery is that someone stated before that these are all large fish. That is not the case. We have seen for the last several years that there is a fairly good spread of year classes. Indeed, we have had times fishing out there where you have two and three year old fish which is not the norm.

Something is happening. I don't know why those fish are out there. I can't answer that and I certainly don't suggest that we have the answer for that but I suggest that the answer is multidimensional and that is why we have to look at all these factors during the amendment process.

There are some very, very significant numbers out there to the point where some commercial fishermen who have looked for other fish and I can reference certain people in Cape May, for example, who have said that these things are really turning into a nuisance.

What you have just mentioned with regard to stopping 20 miles offshore, our fleets this year, and this is an important point that I didn't raise before, 1995 was an extraordinary year in the New York Bight for bluefish. The Barnegators and I mentioned Karter's dad's boat for example and I mention our boats and I can mention 
all the way out to our boats to Montock, we had some extraordinary numbers close to shore. The Barnegators were going on a full day trip but they were doing half-day fishing quite a bit because they caught their quota too fast.

Mr. LARSON. It was almost all half day, the best summer ever.

Mr. BogAN. And it is not supposed to be that way. But what is interesting is tell that to a scientist and they will tell you that didn't happen, what you experienced did not happen because it doesn't fit into a model. They are not trying to be these horrible people toward us, they are just saying that it doesn't fit in the model.

Mr. SAXTON. How far off do these large catches take place?

Mr. BOGAN. The furthest offshore that we had persistent catches was in the 26-mile range offshore-a place called Monsters Ledgewhere the fish could not be found if you did a trawl survey performed during the day.

Recall also please that the trawl surveys done in order to assess stock status are done in the same place year after year. Bluefish are a highly migratory international fish and these fish are popping up on the east side of the mud hole in a very big spread only at night. We can only catch them at night.

Our same boats, guys with 40 and 50 years of experience, can't catch them during the day. Again, that is a factor and we can't explain that although that is consistent with the 1960's when we had very bad recreational catches in the '60's. There was a dearth of bluefish during the 1960's.

Mr. FOTE. Yet if you were a surf fisher on Long Island Beach State Park, you were in the desert last year, you didn't see a bluefish for most of the season. They basically have disappeared from the surf fisherman and very bad catches in the Chesapeake Bay and Barnegat Light.

We were talking about history and what happened in 1945 and one of our newest commissioners, the youngest one who is Stan Blum who happens to be 81 years old, and Stan was a charter boat captain in the 1930's and 1940's and then went into the service and he said that bluefish disappeared all over the place in the 1940's as Ray's chart is showing and then he hit the beaches in Azores setting up a naval base and all of a sudden he found all the bluefish he wanted. He said, "Well, that is where the hell they went." They do move all over the ocean.

There have always been catches when you are shark fishing. There have always been stocks offshore and guys when they are counting your fish have always basically picked up bluefish over the years.

There is some kind of a decline in the stock. I am not going to disagree with that and the surf fishermen have really felt the most of it and the guys in the Chesapeake Bay and Barnegat Bay and the guys in the Rarin Bay. Their catches of bluefish have dramatically decreased and according to them, the stocks have crashed. That might not be the case but according to them, that is how they feel about it.

Mr. RADONSKI. There is no doubt that you can have changes in availability for good reasons. But I would hope that this committee, before making their judgment on the value of science in this fish- 
ery, summon the scientists before them and have an explanation of how they collect their data, where they collect their data and how their models are constructed.

I support the use of anecdotal data. It is good in its place if it is used judiciously. I think that any scientist that would tell Mr. Bogan that what had happened didn't occur, then that scientist would be in question because if he caught the fish, he caught the fish. There is no doubt about it but if you are going to look into what is the proper way to manage these fish and collect scientific data, I hope you will talk to the scientists as well.

Mr. SAXTON. While you have the microphone, you talked about overfishing. Would it be fair to say that overfishing not only occurs on the fish stock that we are concerned about, in this case bluefish, but also on menhaden and other bait fish?

Mr. RADONSKI. Well, it can but the menhaden stocks are in as good a shape as they have been for a long time.

Mr. SAXTON. Oh, is that right?

Mr. RADONSKI. Ýes.

Mr. SAXTON. Inshore?

Mr. RADONSKI. Well, I can't comment on the distribution of them because the practice of harvesting manhaden has changed quite a bit recently. I think the people that are in the manhaden fishery would have to answer that question where they catch them but there are changes in abundance of cray species and one statement that I would subscribe to very strongly that Ray made was that the bluefish/striped bass relationship is not so much direct competition, one fish eating the other, but the competition for a food source.

I think that is very critical and it is one of the more difficult things to demonstrate. You have to catch large numbers of each species and do stomach analysis which is extremely labor intensive and right now the Federal Government has not seen fit to give the National Marine Fisheries Service the money to solve these questions. So I think we aren't going to get these answers until we make the expenditures and I am not just speaking of bluefish. I am talking about all fisheries.

We are going to make our best management decisions based on good sound data and we should be spending more time collecting that data because making decisions for short-term benefit are going to have long-term consequences in the rebuilding of all of our fish stocks.

Mr. SAXTON. It seems to me that we have made and anybody please comment, Frank, I am dominating things here and I don't mean it to be that way, but it seems to me that we have made three general conclusions.

One is that there is fairly broad agreement that the bluefish stock goes up and down and that it is cyclical over time. Number two, there is still a significant biomass population of bluefish offshore and the third is that there has been a decline in the population near shore.

It seems to me if that is all the case, then there are a couple of questions to ask. One, is the downturn in the population offshore significant for us to worry about? That is a question that I don't pretend to have the answer to and the second is why have they left the shore. 
Mr. PAllone. What I was going to suggest and I agree with everything you just said there but again we go back to this question of how are we going to get this information. Ray Bogan was talking to some of the first panel before and suggesting that part of the problem is where is the money going to come from to hire scientists or whatever and it is difficult to pay somebody or hire somebody given the reduced Federal dollars to do a lot of this work and yet I didn't hear anything from the first panel to suggest that we are on our way to really getting this scientific evidence.

If we can come out of today's hearing with some way of moving ahead and do you guys have some suggestions about how we could move ahead and get this scientific evidence either through some Federal funding source or through volunteer efforts on your part? Otherwise, how are we ever going to answer the questions that the Chairman is bringing up?

Mr. BOGAN. If I may to a number of those things, first of all with regard to some issues that Gil raised on, for example, stomach contents, it seems like not such a big part of it but that is something that our industry, for example, because of filet permit exceptions that we have on all species we get a much better idea of stomach contents. We literally filet hundreds of thousands of these fish per year. We do go through stomach analysis. There is a practical reason why we do it however in that practical confine we learn an awful lot that can be added to the process.

Mr. SaXton. It is advantageous to you to know what they are eating.

Mr. Bogan. You hit the nail on the head and if I may, that is where one of the first showings of a decline in sand eels came in. The second one was that our bait boats couldn't find them. We used other boats to find sand eels and they couldn't be found. Sand eels-I can't emphasize how important a forage fish that is.

With regard to the lack of money to obtain data, industry has to contribute and we are doing that. The Recreational Fishing Alliance, for example, is putting together a whole new data collection system that is going to be presented to NMFS after they have had the opportunity to develop it through contractors who have worked for NMFS and Eleanor Bohaneck from Sea Grant.

So industry does recognize that it has a place in the process and we are trying to do that. We are trying to do it with independent people so that our input, and that our proposals, are seen as objective. We don't want to be going in to managers saying, "Hi, I am Ray Bogan, let me tell you how I can count them" because I don't have enough background to do that. The scientists can help direct us on how to incorporate the public and the private sector and that is what we are attempting to do.

Mr. PALlone. But Ray, I guess what I am asking is are you satisfied that NMFS or whoever is in the process over the next few months or years, are they in the process of putting together something that is going to give us the scientitic data so that good management decisions are made and if not, what can we do to effectuate that because otherwise, where are we going?

Mr. BogAN. No, I am not satisfied they are. I think the only way that they do is when folks like yourselves make them. Bluefin tuna and yellowfin tuna are a perfect example. 
If you, both Congressman Saxton and Congressman Pallone, had not interceded and did what you did, NMFS would not have done that peer review for school bluefin. As a result of the peer review, again we were proven correct. I don't think it is going to be any different with bluefish.

If on bluefish we don't put the pressure and the money toward that then NMFS will not take that action. But, the ultimate problem for NMFS that they attribute this to is that they don't have the staff to incorporate the information that we give them once we get it for them.

Mr. PALLONE. I don't know what the answer is today but that is certainly something that we can look into, to make sure that there is the follow-up and that something occurs.

Mr. SAXTON. Just on that point, Frank and I have co-sponsored a bill that seems like it is far away from this subject but it really is not far away at all. It would create an institution to delve into some of these matters like we created in the 1940's to delve into matters that had to do with human health. The National Institutes for Health has come a long way in helping us understand science about a lot of things that nobody knew at one time were even related to human health.

NMFS does research and NOAA does research and the EPA does research. You name the organization and they do some kind of environmental research and yet one organization doesn't know what the other is doing.

So we think that it would be a good idea to have a National Institute for the Environment where this information could be data banked so that people would have access to every piece of information that is known and then we can look at where the holes are to begin to plug in studies and research activities to answer some of the questions.

We are looking today at bluefish which is a tiny little segment of everything that we need to know about to properly manage fisheries. So anyway, that is my soap box. I have been talking about that for six years, along with Frank, or more but I think it is a good approach. I interrupted you, Tom, please go ahead.

Mr. FOTE. I was going to say we have to get to the point where we do ecosystem management. We have to include the whole environment and that is what your bill will basically do, set up the framework to do that.

We ought to look at prey/predator relationships. For example, the sand eel population has gone so bluefish don't come in shore. Stripers are still coming in shore because they are more aggressive in what they feed off, if you look, their bellies are all full of clams.

You can't catch one on a plug because a plug would imitate a sand eel. So you can give up plug fishing so the guys don't sell lures anymore, jigs or anything else but they sell a hell of a lot of clams because that is the bait the fish are feeding on and bluefish can't adapt to feeding on those clams so they move further offshore. That might be one of the reasons why you still get striped bass in shore and bluefish offshore.

Mr. SAXTON. Thanks. I just bought a new plug pole, I just want you to know.

[Laughter.] 
Mr. RADONSKI. Mr. Chairman, I would go on record as endorsing your move to have a centralized data collection system. One system that works fairly well, although the fishery is stressed, is the Atlantic salmon. The Atlantic salmon are managed internationally through NASCO, the North Atlantic Salmon Conservation Organization.

They don't collect any data themselves. This management organization identifies problems by the member countries and they raise management questions which are then contracted to ICES which is the International Convention for the Exploration of the Seas. They answer the questions.

If they don't have the research in hand, they institute research programs to get the answers to the question. I think that is the way we should be managing the fisheries. That presently is being done somewhat by the Mid-Atlantic Council.

The Mid-Atlantic Council does not have a staff that goes out and collects data. They depend on the states and the National Marine Fisheries Service and then they collate all this data. It is just another extra step and another reason that I think that we don't need the Mid-Atlantic Council in the bluefish process.

The last thing I would like to add is when we say that the MidAtlantic Council is not needed in the bluefish plan, we don't mean they are excluded. They still have a seat at the table as Dr. Matlock explained earlier and also my organization does not summarily support removal of the Council process from all fisheries. We are looking at this on a fishery-by-fishery basis and our position only pertains to bluefish.

Mr. Pallone. If I could follow up on that, Jim, the one thing that Gil mentioned that I didn't quite understand, you were talking about the need for a protocol from management between these various councils. You didn't really tell us, do you see that there is a problem right now with this joint management? Have there been problems because of the joint management?

Mr. RADONSKI. Well, we wouldn't be here if there wasn't a problem with the joint management. There is a problem. Really we are still managing on the basis of the Magnuson Act. In 1994 we put a new Act in place, the Atlantic Coastal Fishery Cooperative Management Act.

Mr. PALlONE. But in the case of the bluefish, is there any reason to believe that this joint management hasn't worked? Are there any examples?

Mr. RADONSKI. Well, I can't give you reasons why it hasn't worked specifically in the context of your question. How this protocol would help is that they would identify respective roles in the various fisheries. The protocol should identify fisheries where one or the other organization has a lead. I think that the logical conclusion one would come to in bluefish would be that the ASMFC would have the lead.

Mr. PALlONE. The only reason I mention it is because on the one hand, there has been a lot of expression here about the fact that if you abolish the Mid-Atlantic Council's role or at least the joint management the way it is now, there would be less public input so even though you may feel that it would be better to have one or the other or at least one regardless of which one, I hesitate to 
do that if it meant that the public input was less unless you or somebody could really show that it has really been a problem with the bluefish management.

In fact, if anything when Ray mentioned before, he talked about how this Atlantic States Commission or Committee made the recommendation to reduce the bag limit from ten to three and come up with a minimum size and how there really wasn't any public input into it because it was a committee that did it and that made me, I mean, since they have now rejected that and thrown that out, it makes me think that there is some credence to what Ray was saying.

Mr. RADONSKI. There probably is credence to it but I think that is one of the things that would be corrected in developing a protocol between these two Acts. So we have to take that into consideration.

If you look at the bluefish plan specifically, I went on the MidAtlantic Council in 1992 and left in 1995, when I went on they were talking about we need to do Amendment One. We need to do an Amendment One. They are still talking about we need to do an Amendment One.

Constantly when it was brought up as something that we should do, the Council staff said, "No, we don't have sufficient staff to do it" and they haven't added any people. They have added an economist in the last five years, I think is their only addition to their staff, but they don't have the resources to do it.

The Atlantic States Marine Fisheries Commission is going to be doing it and then we are going to hand it over to the Federal Government and then the Federal Government is going to tell the states how to do it. I think we could eliminate one step in that process.

Mr. Pallone. Ray, could you tell me, this committee of the commission that made that decision to lower the bag limit and all that, there was no public input? Just expand on what you said again, please.

Mr. BoGAN. There was one technical advisor at that meeting. The technical advisors were never incorporated into that process. Dusty Rhodes was the only person there and when the vote came up for an actual limit, rather than an advisory vote, which would allow it to go to public comment and discussion. It turned into a substantive vote of that ASMFC board. It was a joint board with the Mid-Atlantic Council.

However, the commission aspect of it is dominated primarily by head directors of the various states. This board did not allow the public process to be adequately aired with regard to such a significant restriction.

Going from ten fish to three is a monstrous change. It eliminates John Larson's boat from the industry, from that part of the bluefish fishery. We can't survive it, not any three-quarter or all day boats. There is no question about that whatsoever.

As I say in my written testimony, which I request be incorporated into this, you can't resuscitate a dead industry, a dead business. You can't bring it back. Once it is gone, it is gone.

What they did effectively with that three fish limit vote is make a substantive vote which was binding upon the states. If it is binding upon the states, it didn't matter what the council voted. 
Why didn't it matter? Because the ASMFC says, "Guess what, folks, you have to come through State waters, and if you have to come through our waters which we have heard before, we don't care what the council says, you are going to play by our rules" means that the process was eliminated. The council's power was usurped, as was the intent of Magnuson.

Mr. PALlONE. But then what Mr. Dunnigan said before when I asked him about the public input, that would all come after this committee decision, is that the problem?

Mr. BOGAN. It wouldn't even have come afterward. What came afterwards was a huge outcry which resulted in the technical advisors getting together in Virginia in a meeting, which I and a number of other people attended, and putting a great deal of pressure on that board to reconsider its vote and they, therefore, reconsidered.

Blackfish regulations are in the same state right now. We just had this same thing happen with tautog, and not to bring one fishery into another for any reason other than illustration, the tautog may even be more of an egregious affront on the public process because there was a quote/unquote public process there. A review of all of those public comments and I have gotten them all from the Commission now and I added them up.

Not one public comment, nor did the public document, support what was voted on by the Commission. It was a disregarded process. I feel like saying something even stronger about the public process, but I will simply say that it was a process which was disregarded. It never appeared to matter to the commission when a vote was taken.

It was really a show. The vote was taken, as Pat Donnelly who is from the Masquan River Fishing Club pointed out, after a luncheon meeting. This is the effect of the public process for the ASMFC-a 200-mile change in a geographical line affecting fishermen which appeared to result from a luncheon discussion, outside of the meeting and away from the public.

I would submit that until the Commission itself is made accountable, and until the charter is changed, you can't give them a fisheries management plan. It is not just the protocol, and I say that respectfully. It is the charter itself.

It is the inherent make-up of that entity which has to be changed because otherwise it won't, just be a fluke. It won't just be bluefish. It will not just be tautog. It will not just be stripers. It will be others, and that is the danger in my opinion.

Mr. PAllone. All right. Thanks.

Mr. SAXTON. Thank you. I don't have any further questions at this time. I would like to thank each of you for being here and incidentally, I don't believe I asked unanimous consent earlier to have all statements recorded in the record, all written statements that is, and we certainly will do that and so if there is no further business, the Committee will stand adjourned. Thank you very much.

[Whereupon, at 1:54 p.m., the subcommittee recessed to reconvene at the call of the Chair; and the following was submitted for the record:] 


\author{
TESTIMONY OF \\ GARY MATLOCK, PROGRAM MANAGEMENT OFFICER \\ NATIONAL MARINE FISHERIES SERVICE \\ NATIONAL OCEANIC AND ATMOSPHERIC ADMINISTRATION \\ U.S. DEPARTMENT OF COMMERCE
}

FIELD HEARING BEFORE THE

SUBCOMMITTEE ON FISHERIES, WILDLIFE AND OCEANS COMMITTEE ON RESOURCES

UNITED STATES HOUSE OF REPRESENTATIVES

TOMS RIVER, NEW JERSEY

OCEAN COUNTY ADMINISTRATION BUILDING

April 1, 1996

Mr. Chairman and Members of the Committee, I am Gary Matlock, Program Management officer of the National Marine Fisheries Service (NMFS). I am pleased to be here today to discuss the status of the bluefish stock and its future management. With me today is Mr. Mark Millikin, of NMFs' office of Fisheries Conservation and Management.

Today I will review major milestones in bluefish fishery management and answer the subcommittee's concerns. My testimony will address 1) the apparent decline in bluefish stocks, 2) regulatory reform concerning bluefish, 3) the shift of bluefish management to the Atlantic states Marine Fisheries Commission, and 4) amendment of the bluefish fishery management plan, with particular attention to allocation issues.

\title{
BACRGROUND
}

Bluefish is a northeast pelagic fish that is migratory. Bluefish migrate along the Atlantic coast spending winter around Florida, move northward along the entire Atlantic coast during the spring and summer, and return south in the fall. Bluefish are most abundant in water temperatures of $68^{\circ} \mathrm{F}$, but have been found in waters ranging from $8^{\circ} \mathrm{F}$ to $86^{\circ} \mathrm{F}$. Bluefish also occur in the Gulf of Mexico (Gulf), however, there is thought to be little interchange between the Gulf and Atlantic coast stocks.

Landings of bluefish have fluctuated widely during the past century. NMFS has only been able to measure the bluefish population adequately since the early 1980s. This is due to the fact that bluefish primarily supports a recreational fishery, and improved data collection on the marine recreational fisheries was instituted at that time. The highest landings of bluefish that NMFS has on record occurred in the early 1980s, and bluefish $a b i$ dance has continued to decline since then. 
Bluefish support an important recreational fishery along the entire Atlantic coast, with the major component of the fishery taking place in the Mid-Atlantic area. Bluefish also support a small but significant commercial fishery that provides fish to the fresh fish market.

Bluefish management planning started in 1979 when the MidAtlantic Fisheries Management Council (Council) began development of a Fishery Management Plan (FMP) for the species. The Council completed a draft FMP in 1984 to address perceived potential problems of a large commercial offshore fishery developing on the species. The major reason NMFs rejected the plan was that it could not prevent overfishing because states could not guarantee restricted harvest. Also, there was a question of fairness between the different user groups and there was not adequate information to address regulatory impacts.

Following rejection of the plan, the council and the Atlantic States Marine Fisheries Commission (ASMFC) began joint management planning on bluefish, and identical FMPs were completed. The ASMFC completed an Interstate Fishery Management Plan (IFMP) in 1989, and the council completed an FMP in 1990. The FMPs included measures to control fishing mortality by the different user groups, and covered both state and Federal waters. Since that time both the ASMFC, and the council have been cooperatively operating under these FMPs.

The IFMP and FMP are similar documents as far as content. The IFMP, however, was adopted by the ASMFC and recommends to the Atlantic coastal states measures necessary for conservation and management of bluefish in state waters. The FMP was developed by the Mid-Atlantic Council and forwarded to the Department of Commerce for implementation in Federal waters under the Magnuson Fishery Conservation Act.

Commercial catch of bluefish has remained somewhat stable since the implementation of the FMPs. The FMPs call for implementation of a commercial quota once the commercial landings are projected to reach 20 percent of the total bluefish catch (catch is measured as commercial landings plus all fish caught by recreational fishing including fish returned to the water). The 20 percent level was reached a few years ago, and the ASMFC and states have implemented the commercial quota system. However, in recent years, the major factor effecting the determination of the quota system has been the reduction in recreational catch, not an increase in commercial landings.

Commercial regulations are primarily imposed through an overall commercial quota that is individually divided among Atlantic coastal states. The overall commercial quota is designed to be maintained as 20 percent of the recreational catch. It is monitored by the ASMFC and the Council, and maintained through 
ASMFC oversight.

\section{TATU8 OF BLUERISH STOCK}

This subcomittee has expressed concern that the bluefish stock is declining, and if that is the case, what the cause of the predation pressure might be. NMFS is in agreement that the bluefish stock is declining. The latest stock assessment finalized in 1993 found that the bluefish stock is overexploited, and at a low level of abundance, with the recent downward trends in recreational and commercial landings reflecting the declining stock biomass.

The overexploitation of bluefish by fishing in recent years (at least since 1986) certainly is a factor in the continued rate of the decline of bluefish stocks. Other factors such as environmental conditions could also have a role in the decline of bluefish. However, NMFS has not been able to determine if such factors are playing a significant role in the decline of bluefish.

NMFS does not believe that there is new predation pressure on the stocks. Some fishermen have suggested that the recent increases in the abundance of striped bass has had an inverse effect on bluefish abundance because of increased striped bass predation on juvenile bluefish. Considering the fact that striped bass stock abundance has undergone a major increase since 1989, and bluefish stocks were already in a steady decline for a number of years before 1989, it is unlikely that increased striped bass abundance has been a major factor in the decline of bluefish. In addition, water temperature and currents can effect the migratory patterns and distributions of fish. NMFS has not investigated these effects in relation to long term bluefish abundance.

As mentioned earlier, good estimates of population size are available only since the early 1980s. spawning stock reached a historical high in 1986, and has since been in a steady decline. commercial landings over the last decade have remained stable, but recreational landings have declined significantly from 143 million pounds in 1980 to 23 million pounds in 1993.

NMFS has recent statistics on the commercial and recreational catch of bluefish, the market value of the catches, and how bluefish are usually caught.

In 1993, U.S. commercial landings of the species were 10.6 million pounds, valued at $\$ 2,970,000$. In 1994, U.S. commercial landings were 9.8 million pounds, valued at $\$ 2,937,000$.

In 1994 , the recreational catch of bluefish was $11,963,000$ 
fish. Concerning the geographical distribution of this recreational catch, the total represents $2,190,000 \mathrm{fish}$ in the North Atlantic, 5,846,000 in the Mid-Atlantic, 3,444,000 in the South Atlantic, and 483,000 in the Gulf of Mexico.

The recreational fishery accounts for the vast majority of bluefish landings (approximately 80 percent of the total fishery). The recreational fishery takes place primarily in state waters. In 1994, 11.1 million bluefish were taken in state waters versus only about $819,000 \mathrm{fish}$ caught in the EEZ.

\section{REGULATORY REFORM CONCERNING BLUEFISH}

NMFS is proposing to withdraw approval for the bluefish FMP, remove its implementing regulations, and place responsibility for managing bluefish under the Atlantic States Marine Fisheries Commission (ASMFC). The committee has expressed concern about this action. It is important to realize that this decision is being made in the context of a regulatory reform effort NMFs is carrying out agency-wide.

The regulatory reform plan is part of the clinton

Administration's reinventing government initiative to streamline the federal bureaucracy. One initiative under the reinvention activity is a page-by-page review of every agency's regulations, and elimination, consolidation, and/or revision of those regulations that are outdated or otherwise in need of reform. The administration has committed to eliminating more than 16,000 pages of government regulations and more are to be deleted under the reform plan. NMFS is currently conducting such a review with the purpose of becoming more efficient and more responsive to the country's fishing industry. Final action to consolidate, revise, or eliminate almost all of the fisheries service's regulations should be completed by June 1, 1996, meeting the President's timetable under the National Performance Review's reinventing government initiative. This includes considering the elimination of six federal fishery management plans and their implementing regulations. The consolidations and improvements in fishery regulations will be accomplished without weakening the protection for fishery resources.

The six FMPs proposed for elimination are bluefish, American lobster, spiny lobster, stone crab, northern anchovy and the high seas salmon management plans. NMFS believes that there is now authority within the framework of the Atlantic Coastal Fisheries Cooperative Management Act (Atlantic Coastal Act) to manage the bluefish fishery through the ASMFC, a multi-state body that develops management plans for fisheries that range across waters of more than one state on the Atlantic coast. 
There are several reasons why this shift is appropriate for bluefish, which are the following:

1 Bluefish is a species that is found and harvested predominantly in state waters and is an ideal species for management by the states.

1 The ASMFC already has in place an existing Interstate Fishery Management Plan (IFMP) for Atlantic Bluefish.

1 The ASMFC and Atlantic coast states are heavily involved in the management planning for the species in state and federal waters.

The Atlantic Coastal Act is a more appropriate vehicle for advancing states' interests in a species that is harvested predominantly in state waters. With respect to bluefish, the states have already developed a comprehensive management strategy for bluefish, as represented by the IFMP for Atlantic bluefish. If there is a need for additional Federal regulations to buttress the IFMP, the ASMFC can recommend that the secretary take action with respect to the EEZ. NMFS does not intent to withdraw the FMP until the ASMFC has made a recommendation to the secretary enabling Atlantic Coastal Act regulations to be implemented in the EEZ, thereby ensuring no lapse in EEZ regulations during this process.

\section{BLUEFISH MANAGEMENT UNDER THE ASMFC}

The Atlantic Coastal Act gives the ASMFC broad responsibilities to manage marine species such as bluefish in state waters, and gives the secretary of Commerce authority to support ASMFC actions through the implementation of regulations in the Exclusive Economic zone (EEZ), and imposition of moratoria on fishing in state waters when states do not comply with an ASMFC fishery management plan.

NMFS, however, maintains an important and ongoing role with regard to bluefish. NMFS is involved with the ASMFC management of bluefish; NMFS scientists provide technical advice, and NMFS Regional and Headquarters personnel interact with management decision-making bodies such as the ASMFC Bluefish Fishery Management Board. This latter group would have primary responsibility to maintain and monitor the IFMP for bluefish, and for formulating management recommendations for any amendments to it. In the future, bluefish management decisions would be made by the ASMFC with supportive action taken by the secretary in the EEZ or state waters as needed.

NMFS also intends to support the ASMFC, and take whatever supportive measures are necessary for the conservation of 
bluefish, either through issuing complementary regulations in the EEZ or imposing moratoria in state waters when states do not comply with the IFMP.

The proposal to shift bluefish management to the ASMFC will enhance public input by simplifying the number of management bodies the public will have to deal with. The ASMFC has recently implemented a strong program for public involvement in their fishery management program. Therefore, there should be ample opportunity for the public to stay involved under the ASMFC FMP.

\section{AMENDMENT OF THE BLUEFISH FISHERY MANAGEMENT PLAN}

This Subcommittee has expressed interest in ensuring the bluefish stock is managed for growth, especially in light of the allocation issues that will arise as the IFMP is amended. NMFS agrees with this concern, especially since allocation of bluefish has become more of an issue in recent years. The majority of bluefish landings (approximately 80 percent) are taken by recreational fisherman, with over $\$ 300$ million spent annually by recreational anglers fishing for bluefish. The commercial catch of bluefish, however, did recently reach 20 percent of total landings, and is primarily a bycatch of the squid and summer flounder trawl fisheries.

The best way to manage the stock for growth is to control fishing mortality in order to maintain a spawning stock biomass large enough to rebuild quickly the stock when as yet unquantifiable environmental factors favor such rebuilding. NMFs cannot say for certain when the stock will rebuild since the nature and influence of the environmental factors that play a role in stock recovery are largely uncertain.

Through NMFS' partnership within the ASMFC's fishery management planning program, NMFS will remain committed to conserving the fishery. NMFS will rely on the ASMFC to reach fair and equitable decisions with respect to allocation issues in state waters. If NMFS implements measures in the EEZ to support the ASMFC IFMP, such measures must be consistent with the Magnuson Act, which includes standards of fairness and equity.

\section{CONCLUSION}

Bluefish support a very important recreational and commercial fishery along the Atlantic coast. The bluefish resource is overexploited and declining. NMFs believes refocusing management of the bluefish stock on the states through the ASMFC will achieve certain economic and resource benefits. The Federal interest in this important fishery will be maintained through NMFS' ongoing cooperation with the ASMFC under the authority of 
the Atlantic Coastal Act.

Mr. Chairman, I again thank you for the chance to appear here today and I welcome any questions you may have. 
Testimony of

\title{
JOHN H. DUNNIGAN
}

\author{
Executive Director \\ Atlantic States Marine Fisheries Commission
}

before the

Subcommittee on Fisheries, Wildlife and Oceans

Committee on Resources

House of Representatives

April 1, 1996

Tom's River, New Jersey

Mr. Chairman and Members of the Subcommittee,

Thank you for the opportunity to testify today concerning efforts to conserve and manage bluefish, one of the prized recreational and commercial fish species of the Atlantic coast. The process of setting and implementing public policy for the conservation and use of this valuable species presents state and federal fishery managers with a unique and myriad set of challenges, both from the standpoint of the biology of the resource and the human interactions with the species through fisheries. Thus, for the fishery manager, bluefish are a blessing and a bane; at once both interesting and frustrating.

\section{Status of The Bluefish Resource and Fishery}

Bluefish (Pomatomus saltatrix) are a migratory pelagic species generally found in continental shelf waters in temperate and semi-tropical oceans around the world. Off the eastern United States and Canada, bluefish range from Nova Scotia to Florida and in the Gulf of Mexico from Florida to Texas. The stocks in the Gulf of Mexico appear to be separate from the Atlantic, although some mixing doubtlessly occurs. For purposes of fisheries management, the assumption has always been that bluefish along the Atlantic coast comprise a unit stock. Adult bluefish migrate northward in the spring and summer, southward in the fall and winter. Bluefish produce large numbers of eggs, and are sexually mature at about 20 inches, generally age two. Spawning occurs in two principal areas: the South Atlantic bight and the Mid-Atlantic bight. In the South Atlantic, spawning occurs in the spring and fall. In the Mid-Atlantic spawning occurs from June to August. Bluefish grow rapidly in their early years. At one year old they range from 9 to 11 inches; and at two years from 15-20 inches. Bluefish over age 8 are not common. 
At present the bluefish stock in the Atlantic Ocean appears to be in a period of serious decline. Fishing mortality rates have increased from $\mathrm{F}=0.2$ in 1982 to $\mathrm{F}=0.45$ in 1993 . The target fishing mortality rate in the fishery management plan $\left(\mathrm{F}_{\mathrm{msy}}\right)$ to have been exceeded in every year since at least 1986. Stock biomass declined from 326,000 metric tons in 1982, the historic high, to 86,000 in 1993. Of course, we cannot expect record high recruitment on a regular basis. But recruitment since 1989 has been below average, and the 1993 year class of 4 million fish is the poorest in the surveyed 1974 - 1994 time period. Although the NMFS fall survey in 1994 indicated some improvement in recruitment for the 1994 year class, the overall picture is still disappointing. At current stock sizes, in order to achieve the fishery management plan's target fishing mortality rate, the exploitation of the stock would have to be reduced by $50 \%$.

Not surprisingly, the decline in the size of the stock has been reflected in the lack of success of commercial and recreational fisheries. Present recreational harvest levels are approximately 27.5 million pounds (1994), down from 153 million pounds ten years ago; although the 1994 catch was somewhat higher than 1993. Commercial bluefish landings, which had declined by over 33\% to 10.4 million pounds in 1989, increased to 13.8 million pounds in 1990 and then dropped gradually to their lowest value in the time series in 1994 at 8.5 million pounds. Both the recreational and commercial catches in 1994 were significantly below their long-term averages. (1979-1994: commercial average $=13.3$ million pounds; recreational average $=77.2$ million pounds.)

\section{Management of the Fishery}

Coordinated fisheries management for bluefish began in 1989 with the adoption of the Fishery Management Plan (FMP) for Bluefish by the Mid-Atlantic Fishery Management Council (MAFMC) and the Atlantic States Marine Fisheries Commission (the Commission, ASMFC). For federal purposes, the Secretary of Commerce approved the FMP under the Magnuson Fishery Conservation and Management Act in March, 1990. This was the first fishery management plan to be developed jointly by an interstate marine fisheries commission and a regional fishery management council. Throughout the implementation of this plan, the states and the Commission have worked closely with their federal partners in the Mid-Atlantic Fishery Management Council and the National Marine Fisheries Service to carry out the provisions of the plan. 
At the time the FMP was developed the hluefish stock was considered to be fully exploited. The stock had already declined from peak abundance levels observed in the 1980s. The FMP's objectives were to increase understanding of the resource, maintain traditional uses, enhance management, prevent recruitment overfishing, and reduce waste. One provision of the FMP that has proven particularly controversial was the desire of the Commission and the Council to maintain the predominantly recreational nature of this fishery. At the time the FMP was adopted, the commercial fishery was only $10 \%$ to $15 \%$ of the landings. Under the plan if the commercial landings exceed 20\%, the FMP requires action to maintain the mostly recreational character of this fishery. This first happened in 1994, requiring the imposition of state-by-state quotas on commercial fisheries landings. In addition, as the stock has continued to decline, attempts have heen made to constrain recreational fishing effort as well. However, the plan only allows the adjustment of the creel limit, which is a very blunt instrument for management of recreational fisheries.

The Council and the Commission have been actively working on a much-needed amendment to the FMP for over two years. It is clear that a strategy to further reduce fishing mortality must be developed if this species is to recover. The rate of exploitation of this resource is twice what it should be if we are to achieve the FMP's target fishing mortality rates. In addition, lishery managers need a broader suite of tools to address the recreational fishery. Creel limit adjustments that would be necessary to meet the FMP's goals would be unrealistically draconian. The recreational fishing community and the resource would be better served by a more sophisticated approach, that would allow for example the use of size limits, gear limits, closed areas and closed seasons in addition to creel limits.

The commercial fishery too would benefit if fishery managers could consider other measures in lieu of being forced to use only quota changes. In addition, the FMP places the burden of carrying out the commercial fishery quota limitations on the states, and problems have arisen in trying to rationalize quota implementation procedures among the various states.

The Council and Commission held public hearings on the FMP last year and have been working on preparation of the draft FMP. Recognizing that the Mid-Atlantic Fishery Management Council staff has the lead for preparing the necessary documents, the Commission is nevertheless committed to seeing this amendment approved at our 55th Annual Meeting this coming October. The Commission appreciates the efforts of the Mid-Atlantic Council and its staff to keep the preparation of this amendment on schedule. 
There cannot be much doubt today about the fact that bluefish along the Atlantic coast are in significant decline. The information that supports this was summarized previously.

There is, however, no general conclusion available from the scientific community that pinpoints precisely why this decline has occurred. One possible explanation is overfishing and the exploitation of age- 0 bluefish. Fishing mortality has exceeded the fishery management plan's overfishing reference point since at least 1986, and possibly since 1982. However, because of the exploitation of juvenile bluefish, simply reducing overall fishing mortality would not be sufficient to halt the declining spawning stock biomass. According to the Stock Assessment Review Committee forecast for 1995, even if fishing mortality was reduced from the 1993 level of $F=0.45$ to the overfishing definition of $\mathrm{F}=0.20$ and recruitment was average, spawning stock biomass would still decrease by $30 \%$. However, the same forecast indicates that if fishing mortality was maintained, but exploitation of age- 0 bluefish was eliminated, spawning stock biomass would increase by $16 \%$.

An alternative explanation for the stock decline, raised at Amendment 1 Scoping Meetings and ASMFC Advisory Panel meetings, is that interspecific competition and multi-species interactions have influenced either the abundance or availability of bluefish. Bluefish are a minor prey item of bluefin tuna; and I will touch on this in a minute. However, bluefish compete with striped bass and weakfish for prey, and some fishermen suggest that increasing striped bass abundance has impacted bluefish populations. Because the diet preferences of adult bluefish and striped bass overlap, bluefish abundance could be affected if they are out-competed by striped bass and therefore capture less prey. More likely, competition with striped bass may push bluefish farther offshore and thus affect bluefish availability to fishermen. This is possible, because striped bass are nearshore predators, whereas bluefish can and do venture farther out. Since most recreational bluefish landings are taken between 0 and 3 miles offshore, if bluefish are indeed beyond that then recreational catches in traditional areas would surely decline. This theory is difficult to test, because of a lack of offshore fishery independent survey data containing bluefish as well as differing opinions of fishermen. Some fishermen state that those who venture offshore do not target bluefish even though they are available, while others state that charter boats have been going 20 miles or more offshore and still not finding bluefish in abundance. 
Another explanation offered by fishermen to explain the decline of bluefish is that striped bass are preying on bluefish. However, bluefish are not a common prey of striped bass of any age. In fact, the opposite is true. Juvenile bluefish prey heavily on many Anadromous species, including striped bass, and once bluefish reach age l they compete directly with striped hass.

For yet another theory, some fishermen have been suggesting that large numbers of bluefin tuna have been attracted to the coast of North Carolina in recent years and that they prey on bluefish. There are no feeding studies to support this hypothesis; and although bluefin certainly eat bluefish, they primarily feed on menhaden and mackerel. It is not yet known whether the bluefin abundance off North Carolina reflects an overall population increase or a localized event.

While it is possible there is some new, unknown predation pressure on bluefish, there is a lack of data to support this hypothesis. Moreover, the population dynamics of predators near the top of the trophic pyramid are generally influenced more by prey abundance and availability than predation. To address this issue adequately would require past and present feeding analyses of potential bluefish predators, and analysis of the impact of predation on bluefish population dynamics.

The Subcommittee has also asked us to address environmental conditions such as water temperatures that may be affecting the availability of bluefish, perhaps causing them to move off shore. To address this issue, it would be necessary to determine if bluefish are more abundant offshore. Unfortunately, fishery independent of fshore surveys do not capture enough bluefish to reliably estimate offshore abundances. Commercial landings have not declined as sharply as recreational landings. Since most commercial harvest occurs in the EEZ, this suggests that offshore abundance may not have declined as much as inshore abundance. This was supported at Advisory Panel Meetings and Amendment 1 Scoping Meetings held during 1995, when many fishermen stated bluefish were plentiful offshore. However, this could also be somewhat explained by the fact that commercial gear is more efficient and mobile than most recreational gear. Moreover, at a recent meeting of the ASMFC Bluefish Advisory Panel and the MAFMC Bluefish Industry Advisors, many fishermen indicated that abundance was declining offshore and that they were concerned about the condition of the resource. 
If it is a continuing concern that bluefish may be more abundant larther offshore, then possible explanations should be evaluated, including changes in water temperature as well as displacement hy other species. This would require significant biological and environmental research that neither state nor federal scientists are in a position to undertake at this time.

\section{Removal of Fedekal A UTHORITY OVEK BLUEFISH}

On February 29, 1996, the Commission received a letter from the National Marine Fisheries Service indicating its intention to propose the withdrawal of the Secretary's approval of the Bluefish FMP and the rescinding of the regulations which implement it. The letter indicated that this was motivated as part of the Administration's regulatory reform initiative; and averred that cooperative fishery conservation and management by the states under the Atlantic Coastal Fisheries Cooperative Management Act was a more appropriate way to address bluefish management than under the Magnuson :-ishery Conservation and Management Act.

The Commission's Bluefish Management Board and Interstate Fisheries Management Program Policy Board gave brief consideration to this issue at their meetings in Nortolk, Virginia, two weeks ago. Clearly, NMFS will have to propose and justify this action through rulemaking. Presumably, normal administrative processes for fisheries rulemaking, such as environmental and socioeconomic reviews, will apply. Thus, this is not an action that in the Commission's view is going to happen quickly. The agency's stated June 1, 1996, time frame for transfer of authority, and is unrealistic and certainly inconsistent with the amount of time it has taken for virtually any other fisheries management rulemaking. The Commission therefore has not made a judgment concerning the proposed action; but rather will await the Notice of Proposed Rulemaking. However, a few preliminary points are worth noting.

The states are very concerned about the manner in which this action was proposed. As 1 said earlier, bluefish was the first fishery managed jointly by the states and the federal government under a fishery management plan that was prepared by the Mid-Atlantic Fishery Management Council and the Commission working together. This set the pattern for other cooperative, partnership management programs with the Mid-Atlantic Council such as our joint efforts on summer flounder and scup, the latter of which the Commission adopted just two weeks ago. The Commission has undertaken similar programs with the New England Fishery Management Council and South Atlantic Fishery Management Council for American lohster, red drum and Spanish mackerel. When the predecessor to this Committee was considering the Atlantic Coastal Fisheries 
Cooperative Management Act two years ago, you placed great emphasis on the need for the states and the federal government to work together in partnership with the Regional Fishery Management Councils. The states and the Commission have and continue to be committed to this partnership. In this instance, however, the federal government has chosen to announce a major change to the institutional way in which we address management of a major species without first having talked to its partners, or even given them fair notice. This is no way to conduct a partnership.

The timing of this proposed action is unfortunate. The Commission and the Mid-Atlantic Council have been working hard on a major amendment to the FMP for Bluefish. It is essential that we proceed with completing this action this year. The resource as well as commercial and recreational fishermen deserve an up-to-date management program. The credibility of the fisheries management process -- state, federal and cooperative -- depends upon it. The Mid-Allantic Council statf has the lead in undertaking this work on behalf of the state and federal partners involved in the program. Now, however, the Council's authority is in question. It would be a grave crror if this ill-considered action delayed necessary progress in expeditiously completing Amendment I according to schedule.

If together the states and the federal agencies determine that the lead responsibility for managing hluefish should be exercised by the states under the Atlantic Coastal Fisheries Cooperative Management Act, the Atlantic States Marine Fisheries Commission will do what it ean to proceed as expeditiously as possible according to its procedures, including public comment. However, this would require a level of effort that the Commission has not ineluded in its activity planning for this year, and could delay the development of other critical coastal fishery management programs.

Mr. Chairman, the states and the National Marine Fisheries Service have worked hard to improve upon a close and productive working over the past few years. We can only assume that the impetus for this proposal is coming from elsewhere in the Administration. The manner in which this has been handled indicates insensitivity to the partnership nature of cooperative fisheries management planning; and could delay important action to amend the FMP for Bluefish. The states and the federal agencies need to work faithfully together to ensure that these unfortunate results do not occur. That being said, the Atlantic States Marine Fisheries Commission will comment on the substance of the proposal when it is published for comment. 


\section{The Future of Bluefish Management}

Mr. Chairman, you have also asked for comments on the future of bluefish management. Given that the process for developing Amendment 1 is under way it would be presumptuous for me to prejudge what the Commission and Mid-Atlantic Council might decide. It is fairly obvious, however, that some further reductions of fishing mortality, especially fishing mortality on juvenile fish, will be essential. Clearly the need to address both the recreational and commercial sectors of the fishery will make it somewhat more difficult to arrive at final decisions, as it does with virtually every fishery with which we deal. We will be pleased to work with the Mid-Atlantic Council to keep the Subcommittee apprised of the fishery management process as it continues to develop throughout 1996.

Mr. Chairman, thank you for the opportunity to be here today. I will be pleased to try to answer any questions that the Subcommittee may have. 
TESTIMONY OF

DR. JAMES H. GILFORD

CHAIRMAN

MID-ATLANTIC FISHERY MANAGEMENT COUNCIL

BEFORE THE SUBCOMMITTEE ON FISHERIES, WILDLIFE, AND OCEANS

1 APRIL 1996 
I am James H. Gilford, Chairman of the Mid-Atlantic Fishery Management Council. I am honored to be invited to present testimony on the Federal role in the management of bluefish. Please note that the remarks represent my views and have not been approved by the Council.

\section{BLUEFISH RESOURCE}

\section{There seems to be a decline in the bluefish stocks. Why is this happening?}

The Council depends on the Northeast Fisheries Science Center (NEFSC) Stock Assessment Workshop process for information on the status of the bluefish stock. In addition, assessment updates and analyses of management measures are conducted by Council staff and the ASMFC technical committee.

Based on the report of a 1994 Stock Assessment Workshop, bluefish are overfished. The 1993 estimate of fishing mortality exceeded the biological reference point used in the Plan to define overfishing. In addition, the assessment indicated that spawning stock biomass had declined by $74 \%$ from 1982 to 1993 and that recruitment had been poor in recent years with the 1993 year class the smallest in the time series.

There has been some questions about the role of overfishing in the decline of the bluefish stock from 1982 to 1993 . Fishing mortality rates have only recently exceeded biological reference points and the consistent decline in recruitment may largely account for the decline in stock biomass. However, some scientists believe that increases in fishing mortality in recent years should be reduced to stabilize the stock and prevent further declines.

Is there new predation pressure on the stocks? Has there been a shift in water temperature or current which has caused the bluefish to stay offshore after spawning?

Additional analyses are being conducted by NEFSC staff and state personnel to further investigate the status of the bluefish stock. The results of these investigations will be made available to the Council and Commission during the development of Amendment 1 to the Bluefish FMP. To my knowledge, no one is currently evaluating the effects of increased predation or changes in currents or water temperature on the distribution and abundance of bluefish. However, one investigation is looking into the effect of increased striped bass abundance on the decline of recreational bluefish landings. Specifically, the question being addressed is whether or not it is possible that the recent resurgence of striped bass could have displaced bluefish offshore. Since most bluefish recreational landings are attributed to fishermen fishing close to shore, this displacement may partially account for the drop in recreational landings in recent years.

\section{WITHDRAWAL OF BLUEFISH PLAN}

\section{How would this affect bluefish management?}

Withdrawal of Secretarial approval of the Bluefish Fishery Management Plan (FMP), 
developed by the Mid-Atlantic Council under the Magnuson Act with the cooperation of the Atlantic States Marine Fisheries Commission (ASMFC) and the New England and South Atlantic Fishery Management Councils, would be unfortunate and unwise. The National Marine Fisheries Service (NMFS) proposal is that ASMFC would be given responsibility for the Plan and that regulations in Federal waters would be prepared by NMFS under the Atlantic Coastal Fisheries Cooperative Management Act.

In the late 1970's, potential markets for bluefish in Africa and South America stimulated tuna purse seiners to consider harvesting bluefish. This interest prompted concerned fishermen to petition the Mid-Atlantic Fishery Management Council (MAFMC) to develop a Fishery Management Plan for this species. Seven fact finding meetings were held by the Council in early 1979 to give fishermen from Virginia through New England an opportunity to present information on the bluefish fishery. Public attendance at most of these meetings was exceptional. At every meeting the desire for the development of a Plan was strongly expressed by the recreational community. As a result, in May, 1979 the Council held a scoping meeting to develop a work plan for the Plan. The work plan was adopted by the Council in July, 1979 and approved by the National Marine Fisheries Service in March, 1980. Additional impetus to FMP development was provided by the 1982 harvest of bluefish by Florida fishermen using runaround gill nets in Chesapeake Bay.

The MAFMC in cooperation with the NMFS, New England and South Atlantic Fishery Maragement Councils, and the ASMFC completed a Bluefish FMP in 1984. Basically, the plan was based on an allocation system with recreational fishermen receiving $80 \%$ of the total projected bluefish catch each year and the commercial fishery the remaining $20 \%$. Commercial catch was to be further allocated at the rates of $10 \%, 50 \%$, and $40 \%$ to the North Atlantic, the Mid-Atlantic, and South Atlantic subregions, respectively. The difference between the total projected catch for each subregion and the commercial catch in state waters was to be allocated to the commercial fishery in the Exclusive Economic Zone (EEZ).

To serve as the basis of management decisions, the MAFMC, in consultation with the NMFS, planned to submit catch projections each year to NMFS. If catch projections for any user group/area equaled or exceeded $90 \%$ of the user group/area allocation, the Regional Director of NMFS could have instituted control measures such as trip limits, individual vessel quotas, time limits, and/or gear limitations. Also, the Regional Director could have closed the commercial fishery in any area of the EEZ to vessels using non-traditional gear (that is, gear other than hook and line, conventional gill nets, and otter trawls) when $\mathbf{8 0} \%$ of the allowable commercial harvest in the EEZ of that area had been caught by such vessels. Furthermore, the plan established a data collection system, based on permits and logbooks, to facilitate operation of the management system.

However, the MAFMC bluefish plan was rejected by the Secretary of Commerce for the following reasons:

1. The regulatory actions in the FMP were not based upon adequate information concerning the need for and the consequences of proposed action. As such, the regulatory impacts were not quantified as to benefits compared to cost. 
2. There was no immediate urgency for management at the time.

3. The measures in the plan did not prevent overfishing since they applied only to commercial fishing in federal waters.

4. The allocation system of the plan was too rigidly fixed and complex and did not allow for changes in various areas over time.

5. There was a question of fairness in the plan with regard to treatment of different areas and between traditional and non- traditional fishing gear.

Although this Plan was rejected, bluefish remained a major value to the nation and public concerns about bluefish overexploitation were not abated. Subsequently, the Fishery Management Councils and the ASMFC agreed to proceed jointly on the development of a new Bluefish Management Plan containing compatible management measures that could be enacted in both State and Federal waters. This cooperative venture represented a new approach for managing interjurisdictional fisheries. The Bluefish FMP was adopted by the ASMFC at its annual meeting 2 - 5 October 1989 and by the Council 26 October 1989.

The management unit of the Bluefish Plan is all bluefish in U.S. waters in the Atlantic Ocean. This area includes all of the States from Maine through the east coast of Florida and the three east coast Fishery Management Councils. Historically, bluefish landings have been almost equally divided between State and Federal waters.

\section{Will placing sole responsibility for bluefish management with the Atlantic States Marine} Fisheries Commission help the resource?

I believe that the Commission is as concerned as the Council about the condition of the resource. It would be speculative to comment on how a joint Council-Commission Plan might differ from a Commission Plan.

We are working on Amendment 1 to the Bluefish FMP. The Amendment is intended to provide a fishing mortality rate reduction strategy (if the updated stock assessment indicates the resource is overfished) and add other management measures in addition to the recreational possession limit and commercial quota. Council staff with bluefish management experience and a plan writer on loan from the Fish and Wildlife Service are working on that project. If Secretarial approval is withdrawn, Council staff will be assigned to other fishery management plans and Commission and State staffs will need to be brought up to speed. As such, management of this important resource could be delayed.

\section{Will this oroposal affect oublic input?}

Based on the above, It is clear that the Council has a long history in bluefish management. Employees still on the Council staff worked on both the original and current versions of the Bluefish FMP. More important is the Council's tradition of working with the fishermen through its advisory committee process. 
Clearly, the Commission has a requirement to create industry advisory committees and, in fact, both the Council and Commission currently have Bluefish Industry Advisory Committees (which met jointly on 12 March to work on Amendment 1). However, this phase of the Commission's program is relatively new, having been created by the new Atlantic Coastal Act.

The most troublesome aspect of replacing Magnuson Act management of bluefish with Atlantic Coastal Act management is the way the management in the EEZ would work. The Atlantic Coastal Act provides that NMFS may implement regulations in the EEZ that are compatible with an ASMFC Plan. There is no provision for a NMFS industry advisory group.

NMFS has consulted with the Council when it has proposed to implement regulations in the EEZ compatible with an ASMFC Plan. However, having a NMFS employee brief the Council and the Council make recommendations to NMFS is a significantly different level of involvement than working on a plan or amendment for a year or more.

\section{AMENDMENT 1 TO THE BLUEFISH PLAN}

\section{What is the best way to manage the stock for growth?}

When the Council and ASMFC Bluefish Advisors and the Council's Coastal Migratory Committee and ASMFC Bluefish Board met on 12 March, much of the discussion focused on the possibility of using the summer flounder model for the Bluefish Amendment. This would involve setting a fishing mortality rate target, applying that target to a stock assessment to calculate a total allowable catch, and allocating the total allowable catch to the recreational and commercial fisheries based on some agreed upon formula (for example the $80 \%$ recreational, $20 \%$ commercial in the current Bluefish FMP).

\section{Is it possible to do so?}

Yes. The system is working for the summer flounder fishery. There have been a number of Amendments to the Summer Flounder FMP to refine the system, and another is currently in development. There is no reason to believe that the bluefish fishery could not be managed under a similar system that could benefit from what we have learned in summer flounder management.

\section{Will allocation issues cloud the amendment process, or will protection of the fishery remain the overriding goal?}

Any plan that extends along the entire Atlantic coast and has both recreational and commercial components will have allocation issues. However, there is no reason to believe that allocation issues will outweigh protection of the resource as long as the Amendment is prepared under the Magnuson Act. Fishery Management Plans prepared by the Council must comply with National Standard 1 of the Magnuson Act which requires that "Conservation and management measures shall prevent overfishing while achieving, on a continuing basis, the optimum yield from each fishery for the United States fishing industry." Commission Plans under the Atlantic Coastal Act do not need 
to meet the National Standards.

In conclusion, Secretarial approval of the Bluefish Plan should not be withdrawn. A Plan prepared through the Council process pursuant to the Magnuson Act will assure conservation of the resource while allowing all of the interests represented in the fishery to participate in its development. 
TESTIMONY BEFORE THE U.S. HOUSE OF REPRESENTATIVES SUBCOMMITTEE ON FISHERIES, WILDLIFE AND OCEANS, COMMITTEE ON RESOURCES.

APRIL 1, 1996

ROBERT "DUSTY" RHODES

MID-ATLANTIC FISHERY MANAGEMENT COUNCIL, NEW JERSEY 
Chairman Saxton, subcommittee members and staff, thank you for this opportunity to testify about a species as important as bluefish.

By way of background, I'll direct a word or two toward my credentials relating to these fish and fishery management in general.

I currently hold an At-Large seat from New Jersey on the Mid-Atlantic Fishery Management Council (Council) and serve as New Jersey's recreational bluefish advisor to the Atlantic States Marine Fisheries Commission (ASMFC). I'm also chairman of the ASMFC's Bluefish Advisory Panel.

\section{ISSUE 1.}

As a recreational fisherman whose first exposure to marine angling was aboard partyboats, I have watched bluefish stocks run in cycles since the 1950s, a phenomenon noted by marine scientists. Nevertheless, the relative lack of inshore abundance the past few years has given rise to valid concern for this species. That's not to say, however, that lack of abundance and reduced catches are in themselves proof of sharp bluefish stock decline.

Because of their cyclical nature, their on-the-move predation and their proclivity to "ride the waves of feeding opportunity," bluefish might well be more a barometer of local feeding conditions than we realize. How accurately can we judge $f$ ish abundance and changes to that biomass without also assessing the condition of the inshore food chain and the competitive feeding field? I know of no such interactive study as yet applied to bluefish analysis---or any species, for that matter.

Given a fishery management philosophy which isolates species from the marine interaction logic otherwise tells us exists, it's easy to confuse reduced catches with reduced abundance. Indeed, with bluefish more than other species we run a significant $r$ isk of over-regulating by assuming fishing pressure dominates the biomass paradigm.

Yet I recognize that such pressure might well dominate, notwithstanding arguments to the contrary. Therefore, I suggest that with this species above all others, on-the-water information from recreational and commercial sectors should flavor the scientific "soup" of data before we draw inferences from recent catch declines. The massive body of smaller bluefish reported well offshore in recent years, the unusually huge schools seen in far New England waters and the relatively recent swarms of slammer blues reported in the Florida Keys suggest we reexamine traditional bluefish notions. 
I don't profess to know the condition of bluefish stocks, and recent disagreement between National Marine Fishery Service (NMFS) scientists and ASMFC scientists on that very subject suggest others might not either. But even my relatively short time as a fishery manager prompts me to caution against overreaction.

On that note, the option range is obvious, albeit studded with mine fields: if we don't exert enough control, taking a risk-averse posture, bluefish stocks might precipitously crash; but unless we carefully unravel the bluefish conundrum, we might reduce fishing pressure to a moratorium before discovering such pressure wasn't the culprit after all.

I don't suggest we do nothing. But I also warn against inappropriate action which promotes more a "warm and fuzzy" feeling than resource preservation. Before we fix something, let's make sure it's broken. And before we apply a remedy, let's identify the cause of the break and apply that remedy appropriately.

\section{SSUE 2 .}

The question of which management entity---ASMFC or the Council---should resolve the bluefish dilemma is perhaps as challenging and puzzling as determining the nature of the stock itself. However, I do not believe that assigning sole management responsibility to the ASMFC will benefit the stocks, the fishery participants or the general public.

My reasons do not spring from concerns about management inadequacies within the ASMFC. I acknowledge state directors' expertise in that arena. Structural and philosophical differences which exist between the ASMFC and the Council give root to my objection.

One of Congress' goals when establishing the council system was to ensure public participation in the management process. By a ratio of two public appointees to every state fisheries member, that goal has been reached, and the seat allocation system has become one of the councils' major strengths. No such balance exists within the ASMFC. Legislative appointees are, for the most part, nonparticipants, and governor appointees, with a very few exceptions, are infrequently active. The ASMFC is thus characterized by a decision process rooted almost entirely among state fishery personnel and a less accessible public input process than offered by the council system. Against that backdrop, it's difficult imagining how placing bluefish responsibility solely with the ASMFC enhances Congress' goal of making the management process more 
accessible to the public.

My second objection to a responsibllity shift focuses on the removal of a fishery from Magnuson and National standards overview. To what extent will Magnuson and National standards continue to gulde bluefish management? And what authority will "hold the ASMFC feet" to that fire? It appears that a responsibility shift will have bluefish managed solely by the Atlantic Coastal Fisheries Cooperative Act, which, if I may risk being presumptuous, wasn't the intent of Congress.

My final concern centers on scientiflc data use. Under ASMFC management, NMFS scientific information would presumably be interpreted only by ASMFC scientists, thereby losing valuable peer participation. But if NMFs scientific personnel were to play an active role in technical and monitoring committee functions, one would rightly question the inconsistency of shouldering aslde just the council.

\section{ISSUE 3}

With respect to 1 mprovements to bluefish management, I offer the following thoughts which are in no way complete but which represent my analysis up to this point and which served as my input to the recent ASMFC/Council meeting to launch Amendment 1 to the bluefish plan.

\section{Young-of-year protection}

I don't quarrel with the idea of protecting young fish, but I'm troubled by the lack of data concerning angler participation, numbers of fish caught, mortality, and other factors as they relate to catches of small bluefish. Without more precise data, we are quite likely to set a minimum fish size which totally excludes effort on smaller bluefish without really knowing that a meaningful reduction wlll ensue. When one considers the scup plan, sea bass plan, tautog plan and the potential in the bluefish plan amendment, it's obvious we're slowly leveraging out of the fishery an entire segment of recreational angler: those who fish bays, docks, jetties, backwater shorelines and rivers. I caution against that direction and suggest it's unfair. It also opens the management process to criticism that recreationally, the process favors anglers who can afford to own boats or pay the party/charter boat fare. 


\section{Recreational catches}

Heretofore the bluefish plan has measured recreational catch, not landings (fish kllled and brought to the dock). Thus, calculations of recreational harvest were overstated in that credit for released $f$ ish was not given. I suggest landings plus release mortality are more realistic measurements. This will produce an equal comparison to commercial catch measurements which, although usually expressed in pounds, are nevertheless statements of landings.

\section{Bag limits and minimum size}

These can't be adequately addressed until the stock assessment scheduled for this summer, but to implement either or both recreationally without adequate controls on commercial multi-species, multi-gear and non-selective gear simply begs the issue.

I would suggest that all bluefish caught commercially be considered legal for sale and counted against the overall commercial quota. This would limit regulatory discards. However, let's not overlook the possibility of gear quotas (which I acknowledge could conflict with the discard point).

Also, as was accomplished in the scup plan, commercial discards should be accounted for as is recreational release mortality.

\section{Quota calculation}

I suggest the recreational and commercial quota setting process follow the model of other fishery plans such as summer flounder and no longer be linked to each other. Further, while I won't quibble over whether the split should be $90-10$ or $80-20$, I believe the percentage should be set and not a function of a moving average. Otherwise, underfishing on the recreational side could eventually erode quota allocation unjustly.

Commerclal overages should be subtracted in the following year (and/or season should such measures be implemented). Recreational overages should be considered along the same multi-year average which I recently proposed with sumer flounder. Thus, a one-year spike in recreational catches would not trigger a bag limit cut unless the average for the period exceeded the quota. 
5. Private sale

I continue to be opposed to non-permitted sale of fish to permitted buyers. However, trading at home in one's neighborhood should be outside plan jurisdiction.

\section{Party/charter regs}

While many partyboat operators are concerned about separate categories for such boats versus the private recreational sector, I can't help but think it's time we at least considered it and drafted some models to see how they fly.

7. State vs coastwide quota

In light of the possibility of a coastwide quota in the summer flounder fishery, I believe a similar provision should be examined for bluefish. 
Robert "Dusty" Rhodes 2361 Fire Lane North Southampton, NJ 08088 (609) 859-4013 voice (609) $859-2420 \mathrm{fax}$

\section{CONDITION OF BLUEFISH STOCKS}

A. Recreational catch decline doesn't necessarily prove abundance decline.

B. Contribution of natural cycles as well as fishing pressure need to be evaluated.

c. On-the-water information from recreational and commercial sectors should be a vital ingredient in bluefish stock assessment.

I I BLUEFISH RESPONSIBILITY SHIFT

A. Responsibility shift to the Atlantic Sates Marine Fisheries Commission (ASMFC) isn't consistent with Congress' goal of making the fishery management process more publicly accessible.

B. Moving bluefish outside the reach of Magnuson and National standards is questionable.

C. Scientific peer participation from National Marine Fisheries service (NMFS) would be lost.

\section{I I. BLUEFISH PLAN AMENDMENT SUGgESTIONS}

A. Don't eliminate shoreline fishermen from bluefish angling without a measurement of such fishing impact and possible resource savings.

B. Uncouple recreational and commercial quota allocation process.

c. Identify and resolve commercial gear impact issues. 


\section{UNITED BOATMEN}

OF NEW JERSEY AND NEW YORK

RUMMOND D. BOGAN, Eso.

LEGAL COUNSEL
S01 AMTEUCAN LEgION WAY Pt. Pleasant BCh, NJ 08742 (908) 8929500

Fax (908) 892-8527

March 26, 1996

Congressman James Saxton, Chalrman

Subcommittee on Fisheries, Wild life and Oceans

339 Cannon House Office Bullding

Washington, DC 20515-3003

\section{Dear Congressman Saxton:}

1 represent the United Boatmen of Now Jersey and New York, an organization of charter and head boat owners and operators. Our members own and cperate some of the largest vessels and businesses in the head boat and charter boat Industry on the east coast. I thank you and the committee for the opportunlty to testlfy on the role of the federal government in the management of bluefish. The New York blght is the hub of recreatlonal effort for bluefish on the east coast. We are attributed with over $40 \%$ of recreational bluefish landings. Within the last several years, there has been an apparent decline in bluefish avallability to the traditional bluefish fishery. Does this mean a significant decline In bluefish stocks? The question is not as easy to answer as it may appear at first blush. Many factors, which we feel are inadequately addressed and considered by the plan drafters, should be seriously considered in any stock assessment. The drafters of the Amendment should consider these factors prior to proposing and implementing more restrictive measures which could result in immediate negative impact on small businesses which comprise the base of the bluefish fishery. Please consider some of the following points as to each of these fisheries.

CHANGES IN PATTERNS AND AVAILABILITY OF BAIT AND OTHER FORAGE FISHERIES FACTORS. Since the late 1980's, there have been significant changes in bait pattems and availabllity. The most evident of these is the marked decrease in sand eel abundance in near coastal waters in the mid-Atlantlc region. Sand eels are primary forage for many fish. These changes have resulted in changes in predators patterns. Bluefish are the most obvious. Moreover, there has been Increased competition seen in the last several years In near coastal waters by striped bass. Stripers are one of the few fish which can compete with bluefish for food. While striper numbers have Increased, bluefish avallability has decreased. This pattern has been recorded before in NMFS documents. In 1995, when there was a significant infusion of bait into the coastal waters of the New York bight from the beach out to 12 mlles, we saw an extraordinary amount of bluefish consisting of many different year classes. For example, Bamegat Inlet head and charter boat fishermen experlenced the best bluefishing in over a decade. Boats were coming to the docks early with most customers having reached the bag limit in half the time it might normally take. Similar catches were seen out of the Manasquan Inlet, Shark River, the 
Highlands, Sheopshead Bay. Freeport and Ceptree. Likewlee, in 1894, we had asive movement of fish along the New Jersey and Now York cosest during the month of June. These fish were feeding on lerge bodles of bait fish. Once the bait disappeared, so too did the bluefish. The sclentsts who heve worked on the stock assessments of bluefish largely disregard this type of Information. No formula is presently in place which could consider this information. This should be changed.

SHIFTS IN WATER TEMPERATURE. There have been significant shits in water temperature and current pattems within the last several years. Right at the the that bluefish availabllity was decllning, we saw significant infusions of Spanish mackerel, dolphin and other seml-tropical game fish into the mid-Atlantic reglon. At the same time, there were slgnificant increases in schools of bluefish encountered in the offshore fishing grounds (i.e. 30 miles end more) and In the northem states. Malne fishermen, for example. withessed significant Increases In bluefish catches in the early 1990's, a time in which bluefish were far less avallable to the fishermen In the New York bight.

INCREASED AVAILABILITY OFFSHORE. Within the last several years, there have been significant increases In bluefish avallability In offshore waters. Commercial fishemen from Cape May to Montauk have sometimes complained about this increased availabllity because it impedes their normal fishing patterns. Our boats whlch fish offshore for codilsh, pollack, ling and seabass have reported that certain spots have been overrun by bluefish to the polnt where they often have to leave the area. Why are so many fish appearing in offshore waters? Other than a greater availability of bait (e.g. squid and butterfish), we do not have the answer. However, prior to coming to definitive conclusions regarding over-exploitation of bluefish, we should look at these factors.

ANECDOTAL INFORMATION. The argument for considering anecototal information regarding the status of fish stocks, shifting patterns, and changes in effort has never been as strong as it is today. Three examples lliustrate this fact. A scientfic peer review of the data and conclusions of NMFS scientists regarding bluefin tuna stocks was prompted by industry's insistence that stocks were healthier than NMFS scientists believed. The peer review concluded that instead of a continued decilne in bluefin populations, there was a levellng off of any decline, and most likely a slight Increase. This was an extremely significant conclusion. The anecdotal information provided by fishermen proved to be more reliable as to certaln facets of the population analysis than did the "science". Likewise, atter NMFS closed the angling category for bluefin tuna prematurely in 1995, Congressmen Saxton, Pallone and others persuaded NMFS to reconsider their numbers. Constituents had pointed out to Congressmen Saxton and Pallone that based upon the information available to them, recreational angling category could not have exceeded its quota by more than two hundred tons. As a result of the legitimate questlons raised by those Congresspersons, NMFS performed an internal data reassessment and thereafter sent the data to three university scientists for revlew. They concluded that NMFS catch data had exaggerated the actual catch by nearly $200 \%$. Llkewise, Information provided by the recreational yellowin fishery resulted in a tenfold increase in the number of yellowfin tuna attributable to the recreational sector for the 1992 season. To be falr, anecdotal information has also proved unreliable. However, NMFS sclentists have the abllity to sit through aneedotal "outllers" and incorporate the reliable information Into the data base.

In the case of bluefish, the recreational community, particularty those seasoned veterans 
whose Itvelihoods have depended upon bluentsh, are calling into question the conclusions reached by stock assessors on bluefish. While many of us feel there may be decline, we cannot conclude that stocks are in the poor condition managers contend they are. Moreover, we are convinced that any decllnes has much less to do with fiohing effort and mora to do with some of these other factors. The sclentists are again reluctant to consider our anecdotal information. Why would a scientlst not want to fully consider Information pertalning to balt shifts and reductions. water temperature changes, shifts In massive bodies of fish to the offshore grounds and other factors? No reason is justified. These factors should be brought into the equation qulckly. There Is another factor, however, that is now getting more attention by managers. As avallabllity decreases (availability not necessarly being a lack of fish but rather fish not belng in places where the average fisherman catches them) recreational fishing effort decreases. This decrease in effort is primarly caused by decreased local availabllity (except in 1995) and some redirected effort towards offshore species and stripers. Not only has effort decllned, but we have seen more restrictive bag limits, implemented durlng the time of the supposed decline which has discouraged participation and effort. This is inconsistent with a stock decllne induced by overfishing. Thus, we must look at as many relevant factors as possible when evaluating stock health and patterns.

SHOULD THE ATLANTIC STATES MARINE FISHERIES COMMISSION BE GIVEN EXCLUSIVE JURISDICTION OVER THE MANAGEMENT OF BLUEFISH? The United Boatmen are strongly opposed to ellminating the role of the Mid-Atlantic Council in bluefish management and transferring sole responsibllity to the Atlantic States Marine Fisheries Commission (ASMFC). It Is clear that the ASMFC cares little for the public process and until fundamental changes are made to the Commission, it should not be glven any more power.

A look at the other fisheries Involved in this "reinventing govemment initiative to streamline the federal bureaucracy" will help further explain why bluefish are a poor choice. Splny lobster and stone crabs are located primartly in the waters of Florida and can be managed by Florida regulations. The northem anchovy can apparenty be managed by the state of Califomia, while Alaska's management authority is sufficient to manage salmon. Bluefish, on the other hand, are a hlghly migratory fish. They range in the United States from the Gulf coast all the way to the northem most tip of Maine. Indeed, bluefish have an intemational range. (id.) What basis could NMFS have used in taking management of a highly migratory fish from a reglonal council and placing it with an entity which is responsible for coastal waters? There is only one logical answer and that is politics. This is an entity which is permitted by its charter to circumvent and/or disregard the public process. I respectfully request that this sub-committee insist that the secretary reject bluefish as a specles to be taken over by the commission.

More and more groups are concluding that the commission Is a "good old boys" network. by whom decisions are made behind closed doors. Decislons sometmes appear to be made and voted on based on politics and voting blocks. State directors dominate the boards which make substantive decisions regarding the regulations of various fisheries. It is thesa very boards which tend to make decislons outside of the publlc eye. Prior to Rollie Schmitten including bluefish in this list to be transferred away from the councils, the commission had already attempted to usurp the mid-Atlantic Council's management of bluefish. In 1995, the ASMFC bluefish board, in a move which shocked even those of us Involved in the fisheries management process for years, effectively circumvented the Magnuson Act and the Council system. That board voted for a three fish bag limit during a joint meeting with the advisory board of the MId-Atlantic councll. The bluefish board had the power to bind the commission. The vote was taken, however, prior to the 
bluefish technical advisors having en opportunity to submit thelr Input. Most didn't aven know the vote would be taken.

This demonstrated that the commission saw the technical advisory committee as being Inconsequentlal, and that the technical advisors were appointed for no other reason than to comply with the commlsslon's charter. Neither the tech.ılcal advisors nor the public were given appropriate opportunity to eddress this extraordinarly significant reduction In bag llmits which would have immedlate and irreparable consequences to Industry. Beyond all of that, there was no economic analysis avallable to examine the impact of a three fish bag limit on Industry. The commission obviously did not care. The economic impacts of their actlons on the fishing community seemed to be of no consequence to the commission. Fortunately, a huge publlc outery and pressufe forced them to reconsider that vote.

Another example of the commission's intent to exclude input from the publlc and technical advisors can be seen in the extremely restrictive tautog management plan. A review of the public comments from every public hearing showed that not one comment supported the ultimate vote of the commlssion. Moreover, facets of the plan approved were not even addressed in the public hearing documents. Technical advisors were largely lgnored. This was just another example of the commission's quest for complete control over a fishery. If the commission could get more fisheries under it's umbrella, it can justify more staff, power and appropriations. Based upon it's abysmal history, thls would be a major mistake. The Atlantic coastal Fisherles Cooperative Management Act must be revislted in the very near future to correct the significant problems Inherent in the present commission system. The ASMFC charter must also be restructured to allow for public input This commission needs to be told by congress that the people and constituents of this great democracy are not irrelevant and unimportant. Until legislative reform has corrected the deficiencies in the commission, no fish should be under its sole or exclusive jurisdiction.

AMENDMENT ONE TO THE BLUEFISH FISHERY MANAGEMENT PLAN. The Mid-Atlantic Council and ASMFC are presently considering the first amendment to the bluefish management plan. In order to determine the best way to manage the stock for growth, it is essentlal that a number of factors be incorporated Into the science.

Initially, the amendment drafters must determine whether the base years used to assess bluefish stocks are representative. For example, there have been some extraordinary decreases in bluefish availablity within the last 75 years which have had little to do with fishing effort. For example, between 1924 and 1925 U.S. commerclal landings of bluefish were less than a quarter of a million pounds, compared to 9 million pounds in 1931. (Biological and fisheries data on bluefish, figure 13, please see attached) In 1940, commercial landings dropped to approximately 100,000 pounds. There were recreational decreases at this time also. Likewise, there was a signiflcant decrease in recreational take by recreational anglers in the late 1950's and early 1960 's. (There was a decrease In the amount of commercial catch but not as significant as the recreatlonal decrease.) These decreases in catch were attributable to something other than fishing effort. Was it decreased evailability as a result of changes In balt patterns and water temperatures? We do not know any more now than we knew then regarding those factors. Management, however, cannot responsibly Ignore that question. Another Important factor to conslder is that all the age groups of bluefish are well represented. Nils Stolpe, of the New Jersey Seafood Harvesters, ran the manine recreatlonal fisheries statistical survey information on 
bluefish, from Maine to Florida, into sze frequency formula. He concluded that the "length/trequency data for blueflsh sampled for 1989 to 1982 did not differ algnillcantly (plus or minus one standard devlation) from the average length frequency measures for the period 1979 . 1992 (with the exception of what appears to be atrong 1988-1989 year class)." This is not consistent with significant stock decline.

Other factors, such as the fact that more fisherman release fish than in the past as well as a lower hook and release mortality figure need to be considered. These facts and issues should be contemplated when considering managernent tools and stock assessments.

Finally, an economic impact statement must be prepared to assess the impact of further restrictions. Once a small business is destroyed by overly restrictive management measures which are not justified, that small buslness cannot be resuscitated. Most fishermen can survive sound fisheries management. Amendment One affords us all an opportunity to realize that goal.

Thank you for your consideration of our cormments.

Respectfully submitted,

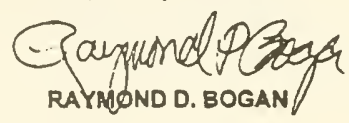

RDB:ck

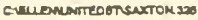




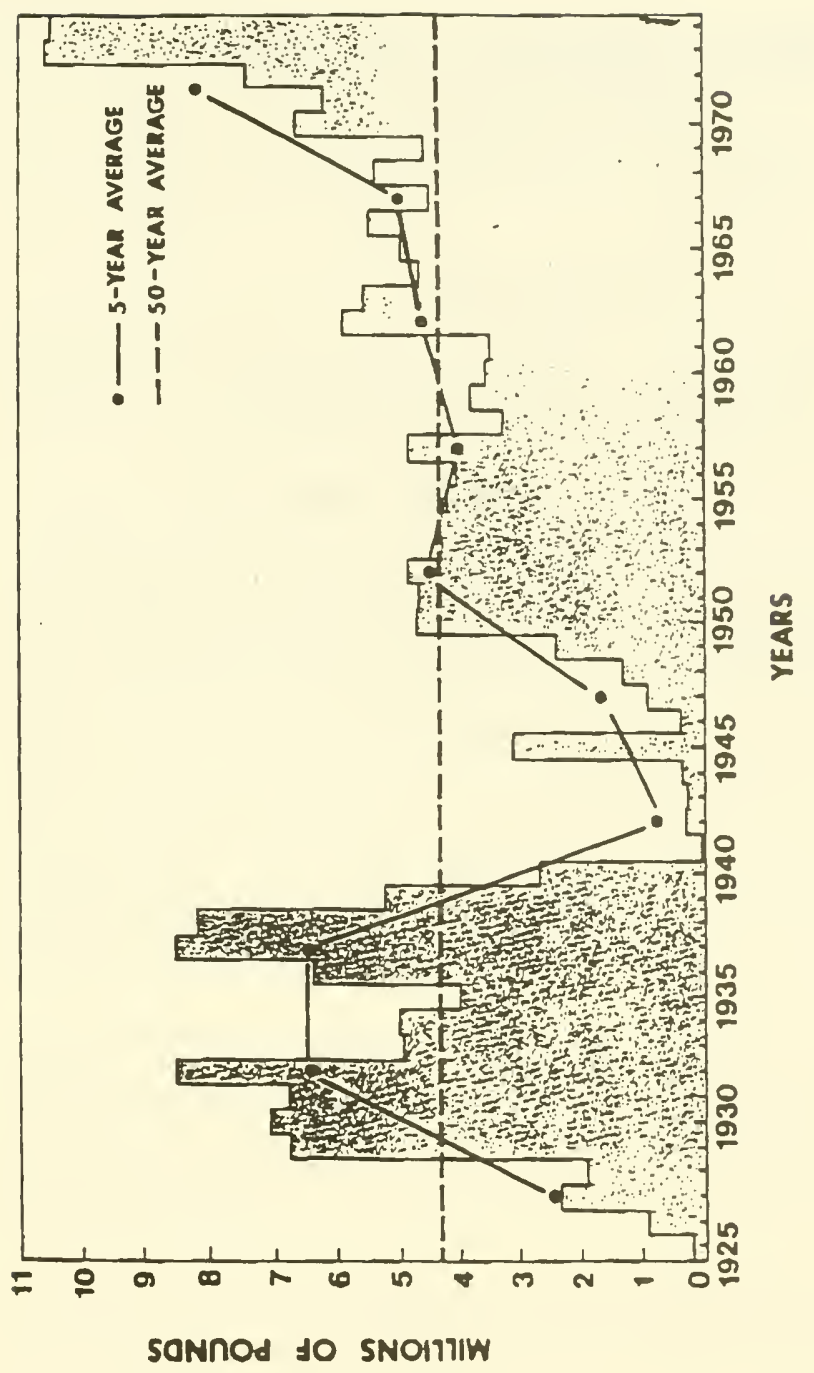


STATEMENT

OF

GILBERT C. RADONSKI AND THE

AMERICAN SPORTFISHING ASSOCIATION

before the

UNITED STATES HOUSE OF REPRESENTATIVES

SUBCOMMITTEE ON FISHERIES, WILDLIFE

AND OCEANS 
STATEMENT

OF

GILBERT C. RADONSKI

before the

UNITED STATES HOUSE OF REPRESENTATIVES SUBCOMMITTEE ON FISHERIES, WILDLIFE AND OCEANS

\section{FIELD HEARING AT TOMS RIVER, NEW JERSEY APRIL 1, 1996}

It is indeed an honor and privilege to come before this Subcommittee to express my views and those of the American Sportfishing Association on the status of management of the bluefish fishery of the United States Atlantic Coast. I feel that I am qualified on the basis of training and experience to offer this Subcommittee guidance as it explores the management of bluefish and endeavors to determine the proper Federal role.

I am a Certified Fishery Scientist (by the American Fisheries Society) and hold the rank of Fellow in the American Institute of Fishery Research Biologists. My thirty-six years of experience includes hand-on fishery management and research with government (state and federal agencies) and in the business world. In 1994 I retired as president of the Sport Fishing Institute, a Washington, DC-based fishery conservation organization supported by the sport fishing industry. I went to Washington, DC in 1975 to become the Executive Secretary of the Sport Fishing Institute and participated in the development of a host of federal legislation that impacts freshwater and marine fisheries in the ensuing twenty years. Among the important legislation that I worked on include: The Magnuson Fishery Conservation and Management Act and its Amendments, the Wallop-Breaux Amendments to the Federal in Sport Fish Restoration Act and The Atlantic Coastal Fisheries Cooperative Management Act. I have been an Advisor to the U.S. Delegation to The International Commission on the Conservation of Atlantic Tunas and the North Atlantic Salmon Conservation Organization, served two three-year terms on the Marine Fisheries Advisory Committee and from 1992-95 was a Member of the Mid Atlantic Fishery Management Council (MAFMC). Since my retirement in 1994 I have been a consultant to the American Sportfishing Association.

The American Sportfishing Association represents the environmental and business interests of the sportfishing community. The primary goal of the ASA is to ensure the availability of a heathy and sustainable fishery resource. Our nearly 700 members, spanning a broad spectrum of the sportfishing community (including manufactures, retailers, conservation and advocacy organizations as well as state and federal fisheries agencies) recognize that a sound resource is the basis for a sound industry and, as such, are united in their commitment to ensure proper management of fisheries.

Changes in the abundance or the availability of popular gamefish, such as bluefish, have a dramatic impact on angler expenditures. The changes in the expenditures reverberate throughout the entire economy, causing shifts in employment, state and federal taxes, and the amount of 
dollars which sport fishing manufacturers pay into the Sport Fish Restoration Account which funds many of the research and management activities conducted by the states. A drop in anglers pursuing bluefish from approximately 12 million in the mid 1980's to approximately 8 million in the mid 1990's for example, created a potential shift in angler expenditures of nearly a quarter of a billion dollars! This reflects simply the shifts in direct expenditures and does not incorporate any multipliers which would account for shifts in secondary activity generated by these expenses.

Mr. Chairman, your letter inviting me to testify before this Subcommittee identified three areas to be explored at this hearing: the status of the bluefish stocks; proposed shift of fishery management authority from federal to the Atlantic States Marine Fisheries Commission (ASMFC); and, what kind of management is needed to rebuild the bluefish stocks. I would like to briefly address those issues in turn.

The status of the bluefish stocks is problematical. The stock is considered to be over-exploited and at a low level of abundance. Stock biomass has declined from 392,000 metric tons (mt) in 1982 to $89,000 \mathrm{mt}$ in 1983, a drop of 77 percent. Present recreational harvest is about 20 percent of what is was in 1987. From the recreational fisherman's view point, bluefish, just a few years ago the mainstay of the Atlantic coast recreational fishery, has become an elusive catch with the average catch going from nearly three pounds per trip nine years ago to slightly more than one pound per trip in 1995. All indices indicate a continuing decline of bluefish stocks, the only remaining question is how low will the stocks go?

The most recent Stock Assessment Review Committee (SARC) findings, completed in 1994 revealed Atlantic coast bluefish populations to be substantially "over-exploited and at a low level of abundance." Historically bluefish stocks have fluctuated and there is good reason to believe that the current low levels of stock abundance is due to a combination of over fishing and natural fluctuation. The fishing mortality rate (or "F") for bluefish more than doubled from 0.2 in 1982 to 0.45 in 1993. Due to a lack of reliable fishery data the true natural and fishing mortality (combined, equals total mortality) are difficult if not impossible to accurately define.

Unfortunately, there has not been an updated comprehensive stock assessment since 1994. Since that last assessment, scientists have recognized some possible deficiencies in the method used in aging bluefish, which may slightly change the assessment results. But until a new assessment is complete, we must act upon what we know to be the facts. The signs of a stock in peril continue to be echoed in statistic after statistic:

* The recreational catch dropped to less than $25 \%$ of the catch levels experienced in the days of healthier stocks in the early 1980 's;

* Commercial harvest levels are at historically low levels;

- The average size of caught fish has declined drastically;

- The abundance of spawners has declined by over $74 \%$, 
* The number of juvenile fish being produced has declined substantially since 1984 and has been below average since 1989; and,

* Recruitment of juvenile fish to the spawning stock has been poor.

Whether we continue to delay and wait for a new stock assessment or not, these facts shout out that bluefish stocks are experiencing substantial declines and we must take action now to avoid pushing them even lower through excessive fishing. The July 1995 MAFMC Bluefish fishery management plan (FMP) review indicated that exploitation must be reduced by $50 \%$ to achieve the target fishing mortality rate, and we must start down the road to achieve that end. The only dynamic affecting bluefish stock size that can be manipulated is fishing mortality and pushing the stocks to exceedingly low levels may jeopardize or greatly diminish the chances for a full recovery. There is just too much we don't know about bluefish, therefore management measures must be extremely conservative. It would be foolhardy to pin our future hopes on anecdotal information that claims the ocean is full of big bluefish just over the horizon.

Next, the question of who should manage the bluefish fishery. That question has been brought to the fore with the recent proposed action of the Secretary of Commerce to deactivate the current Bluefish FMP. There is no doubt that the current co-management by the MAFMC and the Atlantic States Marine Fisheries Commission (ASMFC) is cumbersome and gives credence to the public's lack of confidence in government's ability to run their business smoothly, effectively and efficiently. One only has to attend a joint meeting of the MAFMC's Coastal Migratory Committee and the ASMFC's Bluefish Board to see why the fishing public questions government ability to manage the bluefish stocks. From that perspective, I think it is appropriate for Congress to assess the proper role of the federal government in the management of bluefish. The Bluefish FMP was adopted by the MAFMC in October, 1989 and NOAA approval came in 1990. The MAFMC heaped praise upon itself for launching an FMP for a "healthy" fishery. However, the FMP was fatally flawed from its inception. The plan may not be the reason for the decline of bluefish stocks but it certainly tamished the luster of the MAFMC in the eyes of the recreational fishing industry and recreational fishermen. Among the plans shortcomings were the lack of management options built into the plan (the antithesis of framework flexibility), linking commercial allocation to recreational catch, punishing recreational fishermen for practicing catch and release, and giving the commercial fishing sector a higher proportion of the catch than was historically demonstrable. The historic recreational/commercial ratio of bluefish harvest was $85 / 15$ from 1979 to 1989 , the Council's FMP targeted the ratio at 80/20. The Council exacerbated their standing with the recreational fishing community when they devised a grossly unfair methodology for predicting the next years recreational catch in setting the bluefish commercial quota when the plummeting bluefish stocks triggered an FMP mandated commercial quota. [NOTE: The commercial harvest did not rise, rather the severe decline of recreational harvest greatly changed the recreational/commercial ratio in excess of $20 \%$ triggering the commercial quota setting process.] The methodology knowingly overestimated the recreational catch which rewarded the commercial sector with higher quotas than which were realistic, leading to increased over fishing. Since 1990 the split has been of the magnitude of 70/30 when using the Council's unbelievable mandate of measuring the commercial catch by landings (fish brought to the dock and sold) while the recreational measure was their catch (including fish 
caught and released alive! - see Figure 3). If a more realistic method is used of equating recreational fishing harvest (MRFSS A + Bl fish) with commercial landings the split exceeded $70 / 30$ and actually approached $60 / 40$ ! (see Figure 1)

What has the MAFMC done to correct the badly flawed Bluefish FMP? Nothing! During my three year tenure (1992-95) the Council toyed (used advisedly) with drafting Amendment One to the Bluefish FMP. They are still toying with it... Some would say that the ASMFC shares culpability for the faulty Bluefish FMP since it was developed as a joint plan. I would answer that with the observation that the ASMFC of 1996 is far different than the ASMFC of 1989. Of singular difference is the passage of the Atlantic Coastal Fisheries Cooperative Management Act (ACFCMA) of 1994. The ASFMC's standing in the management of Atlantic coast fisheries was significantly enhanced with passage of that legislation. In addition to standing, the Act increased ASMFC's resources to carry out greater responsibilities.

In my opinion it is entirely appropriate for the Secretary of Commerce to withdraw the Bluefish FMP, notwithstanding the rationale of reducing federal regulations. If carried out the withdrawal of the Bluefish FMP will greatly reduce the duplication of effort between the ASMFC and the MAFMC. Mr. Chairman, in your letter of invitation to testify you asked if such a move would help the resource. That is problematical, but it certainly will help the public in focusing their efforts to participate in bluefish fishery management while reducing government duplication. From the recreational fishing community's standpoint it makes sense because a great preponderance of bluefish fishing occurs in the territorial sea (see Figure 2). Such a move will not exclude federal participation in bluefish management it will merely change the lead for the Bluefish FMP to the ASMFC. The Secretary will continue to have responsibility for bluefish in the Exclusive Economic Zone (EEZ) and the National Marine Fisheries Service will have a place at the ASMFC's bluefish management deliberations. In fact, as with other coastal fisheries it is imperative that ASMFC and the National Marine Fisheries Service work to avoid creating enforcement loopholes due to inconsistencies in state and federal regulations. It has been said that the ASMFC does not provide for adequate public participation in the management process. It may not be exactly like the Magnuson Act's public participation process but I believe it is adequate. Each ASMFC member state has its own public participation process for public input. I would add that endorsement of an ASMFC lead for bluefish is not summarily extended to all fishery management plans. That must be done on a plan by plan basis. It would behoove the ASMFC and the MAFMC, the New England Fishery Management Council and the South Atlantic Fishery Management to get together and develop a protocol for interjusidictional fishery management in the light of passage of the ACFCMA. That is not a novel idea, Congress implied such action in the Findings and Purposes [Section 5101 (a) and (b)] of the ACFCMA.

The final area of concern of this hearing is what kind of management is needed to rebuild the stocks. The simple answer to that question is to minimize fishing mortality and wait for natural condition that are conducive to bluefish spawning and recruitment. That seerns crass, but identifies the range of options. With regard to specific recommended changes in the Bluefish FMP, it must be amended to be more flexible in regard to management options to reduce fishing mortality. The states should be given a great deal of latitude to reach management objectives. It is time to use conservation equivalencies in management as well identifying and quantifying all 
fishing mortality by-catch in commercial and recreational fisheries so steps can be taken to reduce it. A realistic rebuilding schedule should be developed and adhered to, all too often fishery management plans have rebuilding schedules are changed whimsically when there is a slight upturn in the fish population. Bringing fish stocks to recovery requires staying the course. The target/quota method of setting harvest limits respectively for recreational and commercial fisheries should be continued with the historic $85 / 15$ split based on fishing mortality, not catch. For clarification, a quota for commercial fisheries can be used because their landings are more readily tracked. The recreational catch is a target mortality adjusted with size and bag limits as well as seasons, overage and underage should be applied to the ensuing fishing season in both cases. The target/quota method has been used effectively for such fisheries as summer flounder, king mackerel and others.

Mr. Chairman, you asked the question, "Will allocation issues cloud the amendment process, or will protection of the fishery remain the overriding goal?" Allocation of scarce fishery resources is a political process and it will be hammered out in the political arena, that is the way it has been and that is not going to change. Protection of the fishery resource is political also but that question has been debated in the best tradition of the democratic process and resulted in the enactment of the Magnuson and ACFCM Acts. It is time that those laws be fully utilized to give the protection to the fishery resource that they promise. To delay or avoid protection and rebuilding of fish stocks because that action will cause short-term economic hardships to some segments of the fishing industry (both commercial and recreational) pales in comparison to the economic hardship accomplished somewhat more insidiously by overfishing many fishstocks and dampening the larger economic benefits that can be obtained from higher sustainable yields.

\section{SUMMARY}

- Bluefish are traditionally one of the most important species to recreational anglers on the East Coast.

- The bluefish population has declined 77\% between 1982 and 1993.

- Catch levels are less than $25 \%$ of the levels of what they were in the early 1980 's.

- Annual recruitment to the spawning stock since 1989 has been lower than average and continues to decline.

- Since 1990, the intent of the fishery management plan (implemented in 1989) to cap commercial fishing at $20 \%$ of recreational catch has been exceeded each year.

- Since commercial landings are based on recreational catch (including those fish released alive), recreational anglers are actually penalized for releasing their fish.

- While stock size has declined. recreational catch (and harvest) have also declined, but commercial harvest has increased as a percent of recreational harvest. 
- The present fishery management plan is not flexible enough to implement all management (options including seasons, sizes. and bag limits).

- If Amendment One is approved later than July 1996, new restrictions on harvest will not take place until 1998 at the earliest 


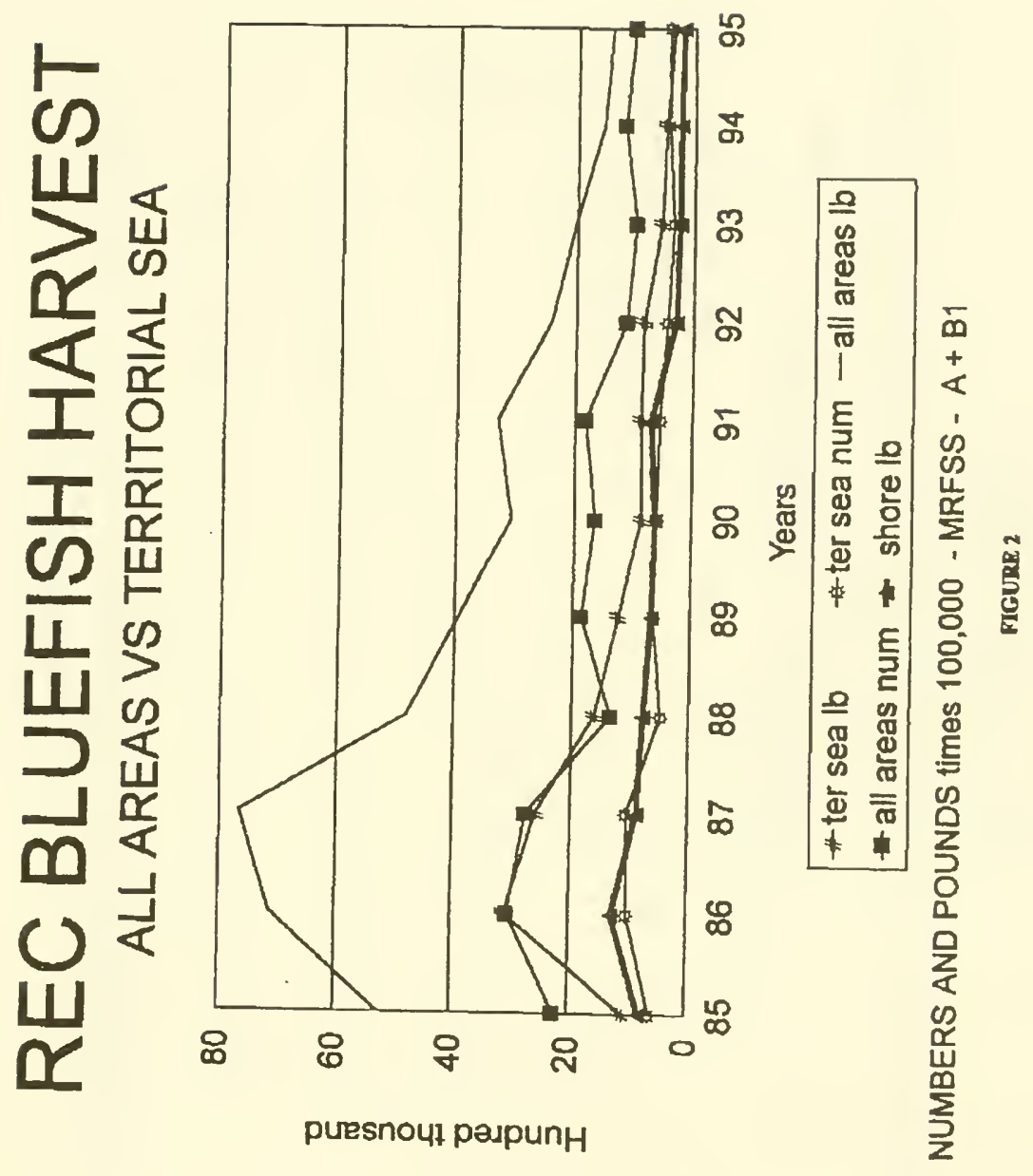




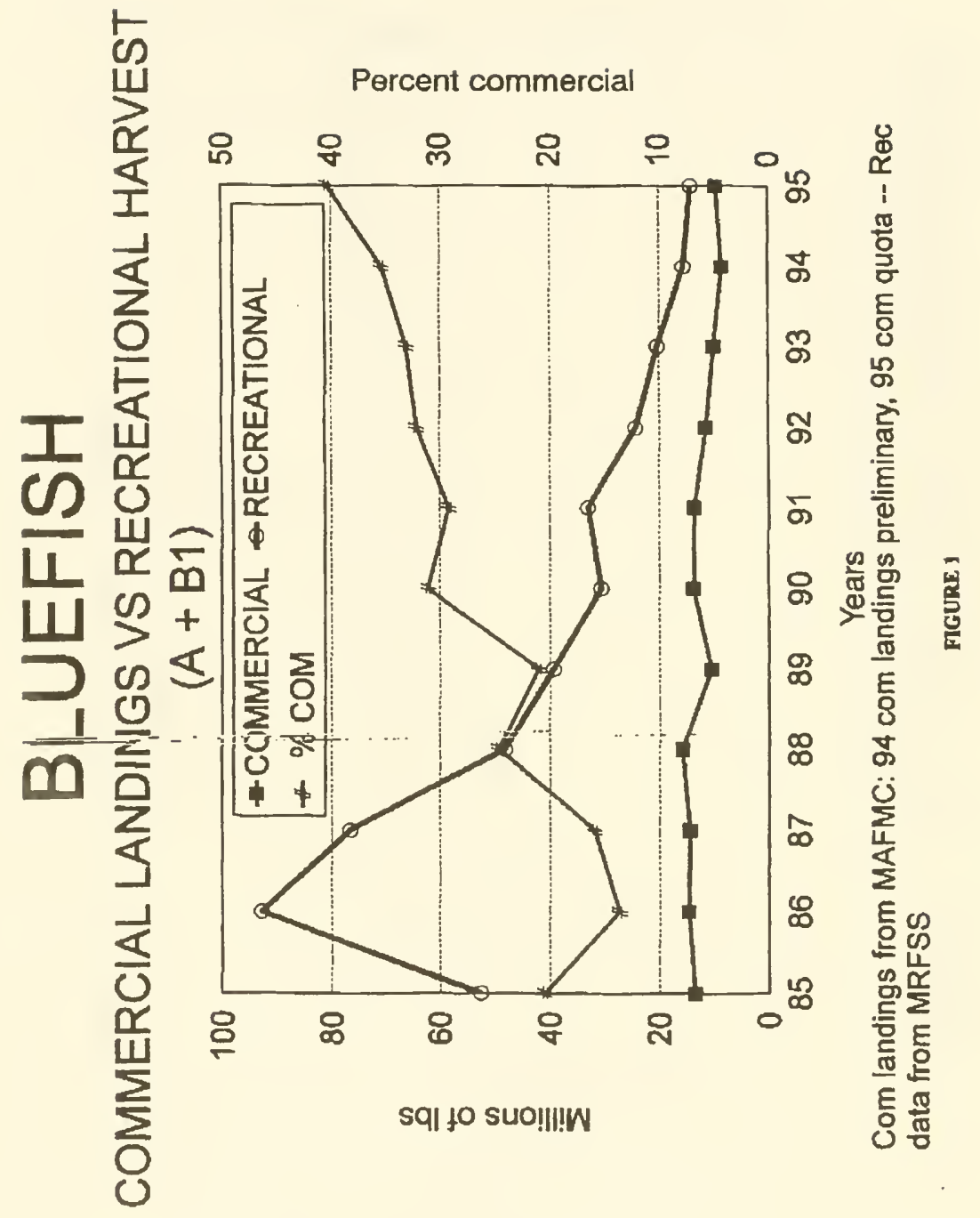




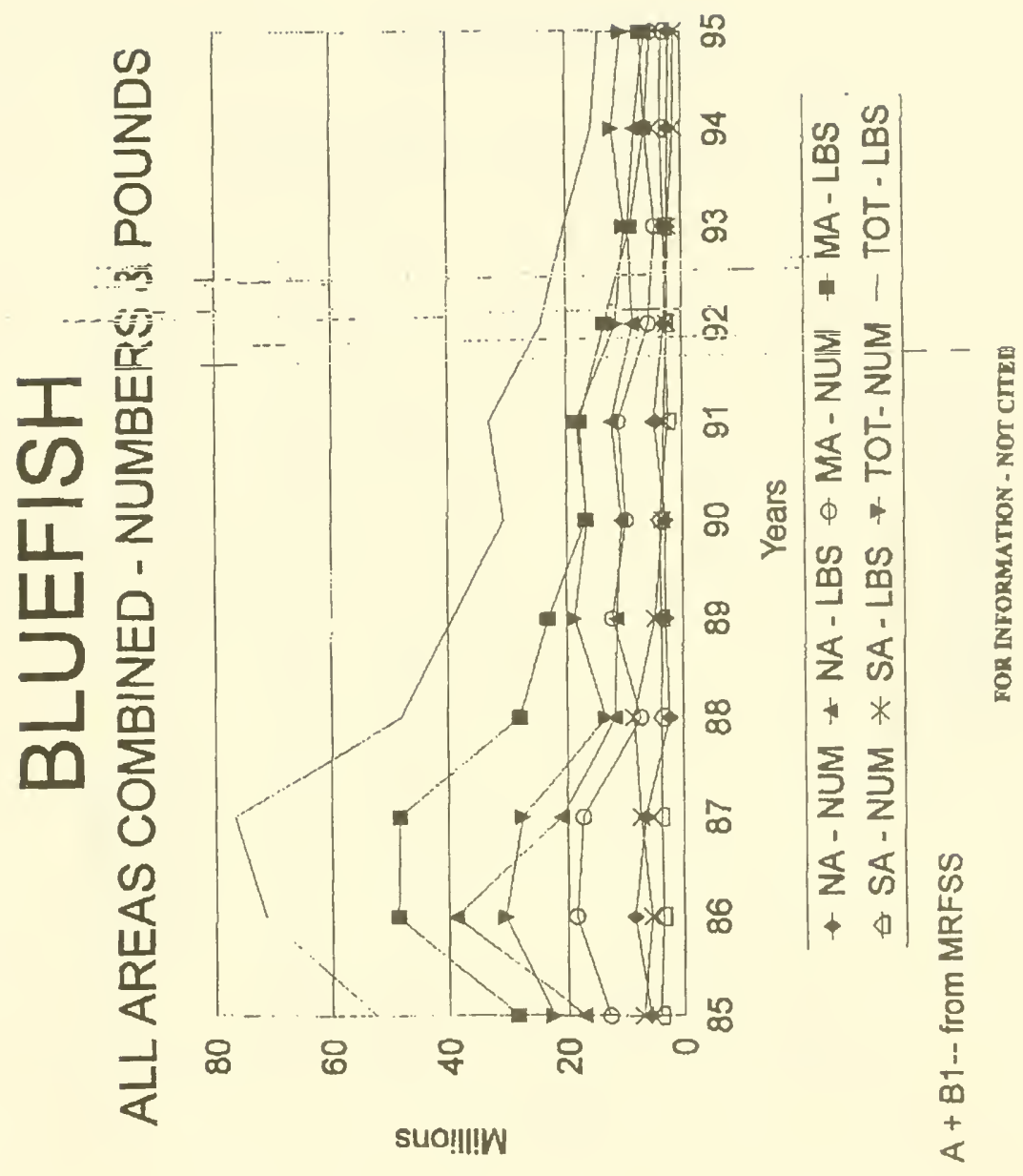


Percentage released

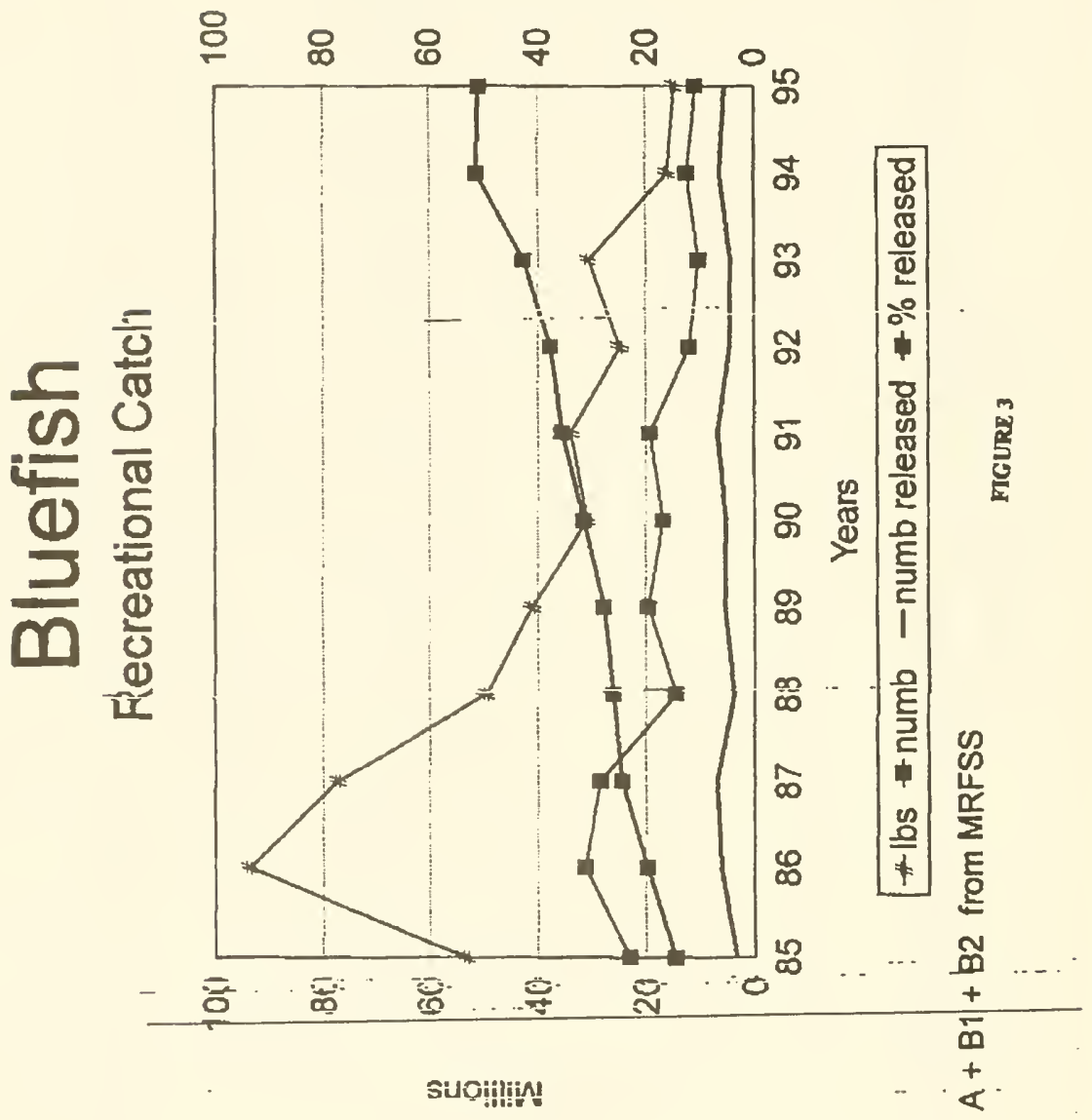



